University of Louisville

ThinkIR: The University of Louisville's Institutional Repository

Electronic Theses and Dissertations

$12-2013$

\title{
Cultural interpretations of Socratic and Confucian education philosophy.
}

Wang Heng

University of Louisville

Follow this and additional works at: https://ir.library.louisville.edu/etd

\section{Recommended Citation}

Heng, Wang, "Cultural interpretations of Socratic and Confucian education philosophy." (2013). Electronic Theses and Dissertations. Paper 605.

https://doi.org/10.18297/etd/605

This Doctoral Dissertation is brought to you for free and open access by ThinkIR: The University of Louisville's Institutional Repository. It has been accepted for inclusion in Electronic Theses and Dissertations by an authorized administrator of ThinkIR: The University of Louisville's Institutional Repository. This title appears here courtesy of the author, who has retained all other copyrights. For more information, please contact thinkir@louisville.edu. 


\title{
CULTURAL INTERPRETATIONS OF SOCRATIC AND CONFUCIAN EDUCATION PHILOSOPHY
}

\author{
By \\ WANG Heng \\ B.A., Beijing Institute of Technology, 2000 \\ M.A., Beijing Foreign Studies University, 2003
A Dissertation
Submitted to the Faculty of the
College of Arts and Sciences of the University of Louisville
in Partial Fulfillment of the Requirements
for the Degree of \\ Doctor of Philosophy \\ Department of Humanities \\ University of Louisville \\ Louisville, Kentucky
}

December 2013 
Copyright 2013 by WANG Heng

All rights reserved 



\title{
CULTURAL INTERPRETATIONS OF SOCRATIC AND CONFUCIAN EDUCATION PHILOSOPHY
}

\author{
By \\ WANG Heng \\ B.A., Beijing Institute of Technology, 2000 \\ M.A., Beijing Foreign Studies University, 2003
}

A Dissertation Approved on

Dec. $3^{\text {rd }}, 2013$

By the following Dissertation Committee:

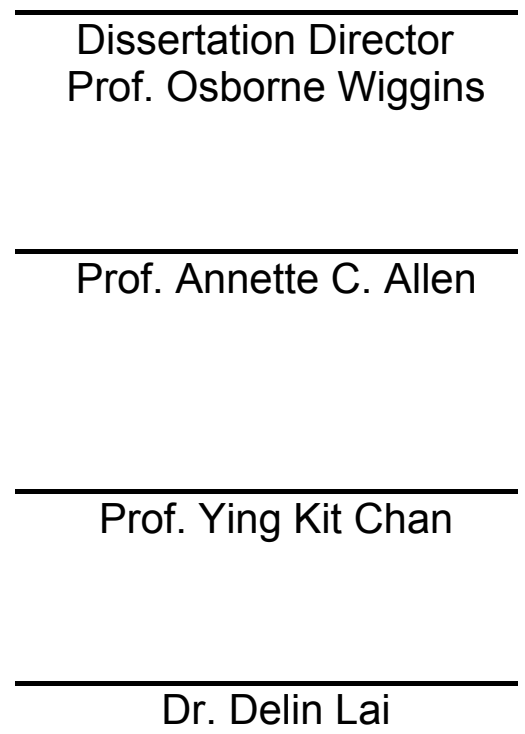




\section{DEDICATION}

This dissertation is dedicated to

LIANG Zuobao (Simon) and LIANG Tianyi(Annie),

my loving husband and daughter. 


\section{ACKNOWLEDGMENTS}

My appreciation, first of all, is for the guidance I have received from the members of my committee. My thanks go to Professor Annette Allen and Prof. Osborne Wiggins, who first kindled my interest in the fascinating field of Humanities, helped me shape the topic, and gave me constant encouragement and support. I am also grateful to Professor Ying Kit Chan for his insightful comments.

Special thanks are due to Prof. Mary James, Prof. David Bridges, Dr. Michael Evans, Dr. Edith Esch, and Dr. Linda Fisher at the Education Faculty of Cambridge University who read and graciously provided comments on parts of the dissertation when I was at the University of Cambridge as a visiting scholar in 2009-2010. I also wish to express my gratitude to my friends Keith Lawn, Clyde Choi and Zachariah Alexander Kornell who read parts of the dissertation and gave me constructive suggestions.

In addition, my sincere appreciation also goes to all my dear friends, especially SONG Nan, WANG Zhenping, WANG Ying, YAO Qihong, LI Xiaoping and WANG Lisha for their enduring care, encouragement and support. They have helped me a lot in overcoming difficulties in life so that I can finally finish writing.

Finally, I wish also to thank my husband, LIANG Zuobao, my five year old daughter, Annie and my parents. They are the source of my strength, confidence and everything. Without their love and support, the completion was impossible. 


\section{ABSTRACT \\ CULTURAL INTERPRETATIONS OF SOCRATIC AND CONFUCIAN EDUCATION PHILOSOPHY \\ WANG Heng \\ Dec. $3^{\text {rd }}, 2013$}

Socrates and Confucius constitute roots of western and eastern civilization respectively, as well as represent very different cultural values and educational traditions. Because of the very limited existing literature on the study of their educational philosophies, this paper is devoted to a comparative study of their educational philosophies, attempting to examine their historical and cultural contexts and unravel their implications on the current educational practices.

The method employed in the study is hermeneutics, or interpretation of the literary texts. At the same time, the study is also cross-cultural in nature.

Both of the philosophers lived around 4-5th century B.C.E., but there were huge differences in the social and cultural environments in which they lived. Different cultural and social factors in ancient Greece and China led to differences in Socratic and Confucian approaches to learning. In this paper, similarities and differences in Socratic and Confucian educational philosophy have been examined from the perspectives of the aim of education, the content of education, the teaching process and the nature of education. It is argued that the epistemological differences of the two philosophers were interwoven with their respective cultural values. Individualistic and rationalist 
traits were embedded in Socrates' education, while Confucius' teaching was distinctively marked with collective and intuitive characteristics. Their thoughts were the product of their own culture, and at the same time, the thoughts of philosophers also left deep impacts on the development of each culture.

Their philosophies of education impacted not only their disciples, but Western and Chinese educational practice as a whole. It has been found that the Socratic traits of individualism and rationality are embedded in Western educational practice, while the Confucian heritage and the collective-intuitive tradition in the Chinese education.

The current study is significant in helping readers gain a better understanding of the philosophers from a cultural perspective. In the same way, educational practice must be understood from multiple perspectives. It is suggested that cultural contexts should always be taken into consideration when studying a particular teaching or learning style. In spite of its limitations, the researcher hopes that the study will help western and Chinese teachers and learners gain a better understanding of one another. 


\section{TABLE OF CONTENTS}

PAGE

DEDICATION ............................................................................................ ii

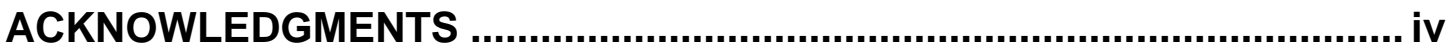

ABSTRACT .............................................................................................. V

CHAPTER I. INTRODUCTION................................................................. 1

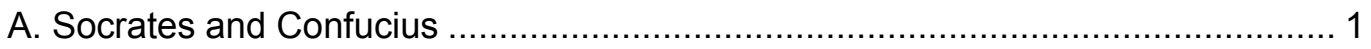

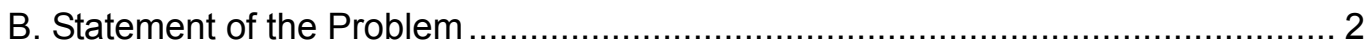

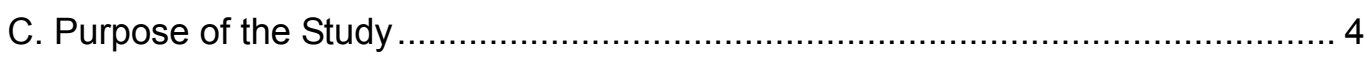

D. Research Questions ............................................................................ 5

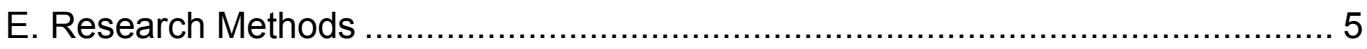

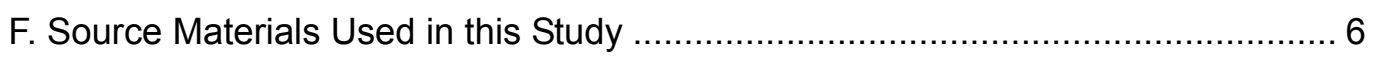

G. Structure (Overview of the Chapters) …................................................. 10

CHAPTER II. LITERATURE REVIEW................................................... 13

A. Philosophy and Philosophy of Education ................................................ 13

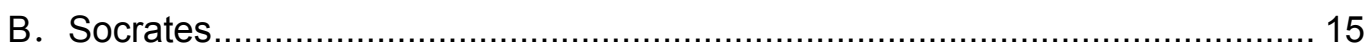

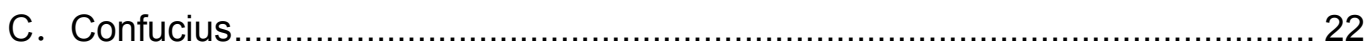

D. Previous Studies on Socratic and Confucian Education Theories ...................... 27

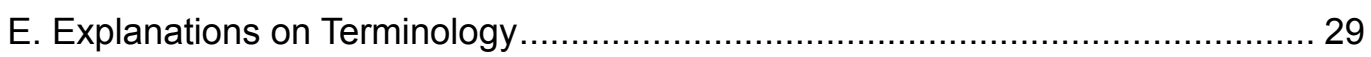

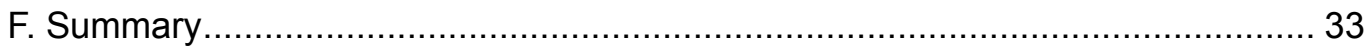

CHAPTER III. HISTORICAL AND CULTURAL CONTEXTS .......................... 36

A. Athenian Society in the 4-6th Centuries B.C.E. .......................................... 36

B. Chinese Society before the 4th Century B.C.E........................................... 64

CHAPTER IV. COMPARISON (CULTURAL INTERPRETATIONS) OF SOCRATIC AND CONFUCIAN PHILOSOPHY OF EDUCATION ........... 83

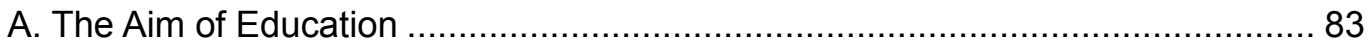

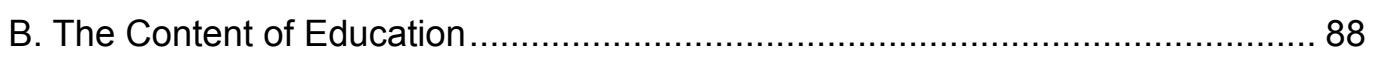

C. The Teaching/Education Process ................................................................. 104

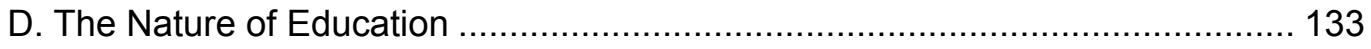

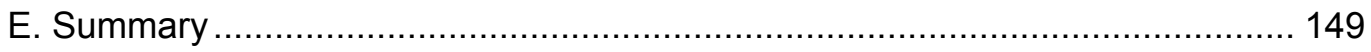

CHAPTER V. THE IMPLICATIONS...................................................... 154

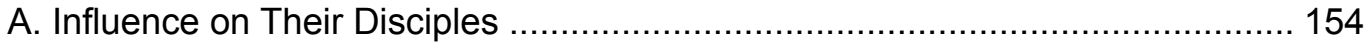


B. Socratic \& Confucian Influence on the Education........................................... 163

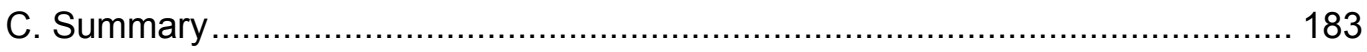

CHAPTER VI. CONCLUSION................................................................ 189

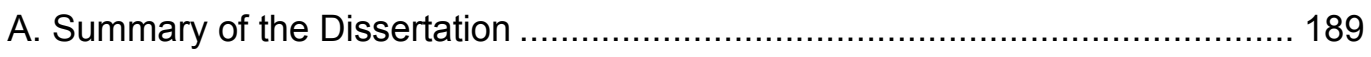

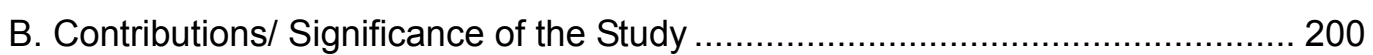

C. The Possible Limitation and Final Remarks from the Author .......................... 203

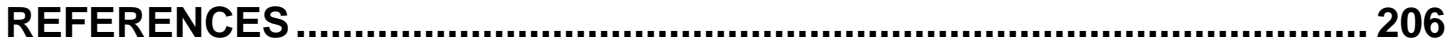

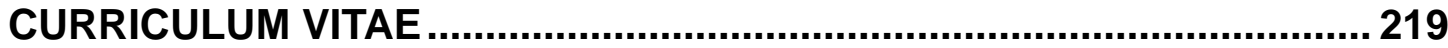




\section{CHAPTER I. INTRODUCTION}

\section{A. Socrates and Confucius}

Socrates (469-399 B.C.E.) and Confucius (551-479 B.C.E.) were two men who exerted a profound influence on Western and Eastern civilizations. Their philosophies and ways of life have been followed by people for over two thousand years. They have been regarded as the "paradigmatic individuals" by Karl Jaspers: the two philosophers are certainly among those people whose "historicity and consequent uniqueness can be perceived only within the all-embracing historicity of humanity" and their influence on the cultures is of "incomparable scope and depth" $(1957,3)$.

Socrates was the best-known philosopher in Athens in the second half of the fifth century B.C.E. As the teacher of Plato, he was known as the gadfly of the Athenians and the midwife to truth. His way of philosophizing and questioning has exerted a profound influence on the development of Western philosophy and education. The Chinese philosopher, Confucius, lived during the late years of the Spring and Autumn Period of China during the 6th and 5th centuries B.C.E. He was a great thinker and educator as well as one of the most learned people in China at that time. The ethics that Confucius promoted and his philosophy have become the very heart of Chinese culture, and his influence upon East Asian intellectual and social history is immeasurable. 
Both Socrates and Confucius were outstanding educators. Socrates "symbolizes teaching excellence" $(1996,616)$ remarks Sichel in Philosophy of Education: An Encyclopaedia; while another huge work, The Shorter Routledge Encyclopaedia of Philosophy identifies Confucius as "China's first teacher both chronologically and in importance" (Lau \& Roger T. Ames, 2005, 141). Socratic questioning has heavily influenced the Western academic world, while Confucius' heritage is central to people's fundamental beliefs in education in countries including China, Japan, and Korea.

\section{B. Statement of the Problem}

Socrates and Confucius have been chosen for this comparative study, because they are the paradigmatic individuals who have exerted far-reaching influence on Western and Eastern civilizations; and they represent very different cultural values and learning traditions. More interestingly, both philosophers lived around the fifth and fourth centuries B.C.E. with contrasting social values and thoughts. Despite the availability of volumes of works about these two philosophers, the comparative study of their educational philosophies themselves have received little attention. Rare are references in the literature to the two philosophers from cultural perspectives. The great strength of Socrates in education has been known by a very limited number of people in China. Similarly, given the extraordinary impact of Confucius on Chinese, Korean, Japanese, and Vietnamese thought and education, it is ironic that so little about this Chinese philosopher is known in the West. Due to limited existing literature and studies on Confucius in Western academia, 
partial knowledge or even some misunderstandings may arise about this ancient Chinese philosopher.

This research problem also builds on an assumption frequently put forward in the literature that the way students learn is affected by cultural traditions (Li, 2002, 53; Salili \& Lai, 2001,239; Cortazzi and Jin, L., 2002, 62; etc.). In this view, each culture engenders a particular style of thought and particular values, resulting in varying perceptions of learning (Cortazzi, M. and Jin, L, 1996, 189). lyengar \& Lepper $(1999,355)$ and Lee $(1996,38)$ also suggest systematic cultural differences in how learning is conceptualized.

In an ever increasing multicultural classroom, Western teachers' different teaching styles or methods cause considerable challenges for Chinese students in their academic learning. A lack of knowledge of Eastern historical and cultural background may also give rise to the stereotypes of Asian students. Throughout their work, The Chinese Learner, Watkins and Biggs (1996) draw attention to the widespread misconceptions about Chinese students. Volet and Renshaw $(1996,205)$ also find "a stereotyped, negative and static view" of Chinese students' learning. The stereotyping as a homogeneous group depicts Chinese students as "rote learners who rely on memorization, lack critical analytical skills, and seldom question the content of what they read" (Pearson and Beasley 1996, 1). Jin and Cortazzi $(1998,753)$, researching the experiences and perceptions of Western teachers working in Chinese schools and universities, report Western teachers as regarding Chinese students as 'diligent, thorough, persistent, friendly' but also 'weak' (orally), 'unwilling'(in group tasks), 'shy,' 'passive,' 'quaint' and 'misguided' $(1998,104)$. Using a Western lens to analyze practices in China, Westerners 
inevitably misinterpret Chinese students' behaviors. Cortazzi. and Li Jin (1996) highlight the propensity for teachers to rely on anecdotal evidence and extrapolation from the specific to the general where there is little "systematic and theoretically-informed research" (180) in defining international students from East Asia. Notwithstanding the fact that some stereotypes may be accurate, there is evidence that stereotypes of minorities or out-groups are apt to be negative, inaccurate and prejudicial, and tend to persist if they go unchallenged; moreover, the intercultural situations which arise may bring conflict in the form of racism and prejudice.

\section{Purpose of the Study}

The purpose of the study is threefold. Although Confucius' ideas about education, ethics, and government are important to a large number of people in the world today, his ideas are still unfamiliar to many in the West. Therefore, one important objective of this paper is to capture the essence of the ancient Chinese philosopher and to introduce him and his ideas on education to the West. This paper may also help to bring to the East the knowledge of Socrates, the Greek philosopher and the roots of Western philosophy.

Secondly, this study takes a cross-cultural perspective. By examining their respective historical backgrounds and cultural contexts from various aspects such as philosophy, literature, art, religion and mythology, economic and political structure etc., we can gain a better understanding of the two philosophers' thoughts, pedagogical methods and their ideas about education. An understanding of the two philosophers' thoughts in the cultural contexts may help us recognize both differences and common ideas in the tradition of 
education in the West and East, and produce findings that shed new light on how learning frameworks are constructed in the different cultures.

Thirdly, through an introduction and examination of the educational implications of Socratic and Confucian philosophies, it will improve the understanding of both the Western and Chinese academic circles about each other's tradition of thoughts. It is hoped that, in such an ever increasingly globalized world, this effort may prove beneficial to mutual understanding, improving intercultural sensitivity and tolerance, and gaining a greater insight into each other's culture.

\section{Research Questions}

Specific questions to be answered by this paper include:

- What were the social and cultural contexts that formed Socratic and Confucian philosophy of education?

- What were the philosophies of education of Socrates and Confucius? How were they different?

- What are the impacts of their educational philosophies on Western and Chinese education?

\section{E. Research Methods}

The method employed in the study is hermeneutics, or interpretation of the literary texts. In doing so, we attempt to seek meaning in texts as they unfold historically. At the same time, the study is also cross-cultural in nature. A cross-cultural perspective refers to the process of looking at cultural 
phenomena from the perspective of both cultures in which they occur (Pusch, $1979,107)$. Such a perspective is chosen to analyze and interpret the data collected in this study because it is hoped that looking at the phenomena from both sides will generate deeper understanding. In this study, we examine the ancient Greek and ancient Chinese historical backgrounds. We try to put the two philosophers' thoughts in their own cultural contexts, and attempt to understand their roots in the socio-cultural climate. The author will investigate the two different learning approaches of Socrates and Confucius and explore their implication in the learning styles of Eastern and Western cultures. Essentially, it is a study of comparison between two different cultures.

\section{F. Source Materials Used in this Study}

Neither Confucius nor Socrates left any major writings. However, in each case their disciples wrote about their lives and teachings in remarkable detail.

Three primary sources in studying Socrates: Aristophanes, Xenophon, and Plato

Every systematic philosopher, whose ideas are perpetuated in voluminous writings, has been differently understood by their followers. This was even more certain to happen with Socrates, who wrote nothing and taught only by word of mouth. It remains an open question just what the real, historical Socrates stands for; and probably none of our most ancient sources can be relied upon to give us anything like an accurate picture of his ideas and methods. As if to fill in the gap, successive individual philosophers and philosophical traditions-from Plato to Nietzsche and beyond—have 
constructed a range of different Socrateses, to serve either as a model for emulation or as a target of attack. Most of what we know now about him has been preserved by three of his famous younger contemporaries, Aristophanes, Xenophon, and, most importantly, Plato. Among them, Aristophanes was a writer of comedies with a strong admixture of satire and farce; Xenophon was a retired general who, though endowed with a strong literary and historical bent, had been for most of his life a man of action; and Plato was a philosopher himself. With these diverse characters and gifts, they naturally saw different things in Socrates and have left us with different impressions of him.

Among them, the writings of Xenophon and Plato are frequently quoted in the studies of Socrates. Xenophon (c. 428-C. 354 B.C.E.) wrote personal recollections of Socrates in his Memoirs of Socrates. According to Xenophon, the activities characteristic of human beings fall into three categories, namely, speeches, deeds, and contemplation or silent deliberation (Mem. 1.1.19; Anabasis 5.6.28). The Oeconomicus is devoted to Socrates' speech, the Symposium to certain deeds, and the Apology to his deliberations, as is made explicit at the beginning of each dialogue. Xenophon's Socratic writings, however, have for the most part not received the attention they deserve, perhaps because those most likely to study them, the scholars of philosophy and political theory, have yet to shake off the view inherited from the preceding generation of scholars, according to which Xenophon was a far better soldier than philosopher (Bartlett, 1996, 1). This deficiency should be rectified, as Xenophon was a competent and authentic philosopher who understood the core of Socrates' life and whose writings therefore reward careful study. After 
centuries of neglect, stemming from indifference or outright contempt, the writings of Xenophon are once again attracting serious scholarly study today.

The philosopher Plato (c. 427-347 B.C.E.) also wrote about Socrates after Socrates' death in 399 B.C.E. Plato's writings are typically in the form of dialogues in which Socrates' discusses philosophical questions with other characters of his day. Most of these are based on known historical figures. Generally, the early works of Plato are considered to be close to the spirit of Socrates, whereas his later works - including the Phaedo and the Republic -are regarded as not representing the historical Socrates' ideas; rather, they are considered to be possibly products of Plato's own elaborations, and the 'Socrates' appearing in them is a spokesman for Plato's own ideas. How far the historical Socrates is accurately represented by the Platonic Socrates has long been a matter of debate (Cooper, 2005, 970; Curren, 2007, 8; Sowerby, 2009, 144; etc.). For both Xenophon and Plato, Socrates is human; neither deifies him. But in Xenophon, the man himself with his possible truth is a rational-ethical being who can be fully known and understood, while in Plato he is a man who speaks from inexhaustible depths, who springs from an unfathomable source and lives toward an unfathomable end (Jaspers, 1957, 16). If the accounts of Plato and Xenophon seem to present a different type of man, the chances are that each by itself is not so much wrong as incomplete, and that to get an idea of the whole man we must regard them as complementary.

In this paper, the writings of Xenophon, Memorabilia, Apology, Symposium and early dialogues of Plato, Euthyphro, Apology, and Crito are selected as the source material in this study. Also Plato's early works are 
preferred because apart from being a disciple of Socrates, Plato was a philosopher himself and he could better understand the depths of Socratic' thought.

\section{The primary source in studying Confucius: the Analects}

For Confucius, the primary source used in this study is $L u n Y u^{1}$, or the Analects, which was compiled by disciples within a generation or two of Confucius' death. It has been generally accepted as the most authentic record of the teachings of Confucius (Chen, 1990, 161; Li, 1986, 146; Martin and Shui, 1972, 8; Tweed and Lehman, 2002, 91, etc.). The Analects of Confucius records the words and deeds of the great Chinese philosopher Confucius and his famous disciples in the Spring and Autumn Period (770- 476 B.C.E.) in China. Finished in the early of the Warring States Period (475- 221 B.C.E.), it is one of the classic works of the Confucian school. The Analects of Confucius records the words and deeds of Confucius and his disciples in the form of quotation and dialogues and reflects Confucius's political philosophies, ethic ideas, moral concepts and education principles. Therefore, the Analects of Confucius is regarded as an outstanding quotation-styled prose collection as well as the masterpiece of Chinese essays. For more than two thousand years the Analects of Confucius has always been esteemed as the must-read book for Chinese people. It has exerted significant influence on Chinese culture and ethics. 
On the issue of translation, the author has striven for the most accurate possible English rendition of the original Greek and Chinese, in spite of the wide gulf between modern English and ancient Greek, modern English and ancient Chinese. Robert Bartlett's rendering of Xenophon's Apology of Socrates and Symposium (1996), and the translation of Plato's Euthyphro, Apology, and Crito by Thomas G. West and Grace Starry West (1998) are adopted in the case of study Socrates. James Legge's translation of the Analects has been our major reference in studying of Confucius. For most of the cases, both English translations and the original words and phrases especially in Chinese are offered for the reference and discretion of readers.

\section{G. Structure (Overview of the Chapters)}

The present thesis is organized into six chapters.

The opening chapter introduces the research topic, making clear the existing problems and objectives of the research. This chapter also raises the research questions, describing the research methodologies and source materials used in the study.

Chapter II presents an overview of the relevant literature, setting the theoretical preliminaries and framework for the following research and analysis. This chapter begins by presenting the concept of philosophy and philosophy of education, and then the great philosophers of Socrates and Confucius are introduced in terms of their lives, their philosophies and their educational philosophies, with a special focus on their approaches to teaching and learning. After the description of the two important philosophers, the strength and weakness of the previous studies on Socrates and Confucius' educational 
philosophy and pedagogical methods are discussed. At the end of Chapter II, the author presents an overview of the related terminologies, i.e. the concepts of teaching and learning, and the working definition of West and East, the definition of culture and cultures of teaching and learning. The working definitions are developed in preparation for the discussion in the following chapters.

Chapter III reveals the historical and cultural contexts of the philosophers. Both philosophers lived around the fifth and fourth centuries B.C.E., but there were huge differences in the social and cultural environments in which they lived. This chapter explores the different historical and social factors in the fifth and fourth centuries B.C.E. respectively in ancient Greece and China, and the resulting differences in Socratic and Confucian approaches to learning.

In Chapter IV, the central part of the dissertation, a comparative study is conducted on the educational philosophy of the two philosophers. Socrates and Confucius came from two widely different cultures, namely ancient Greece and ancient China. Both of these men spent their lives learning and seeking wisdom and leading good lives, but they took different approaches due to their own cultural contexts. In this chapter, similarities and differences are found and analyzed in Socratic and Confucian education philosophy respectively in perspectives of the aim of education, the content of education, the teaching process and the nature of education.

Chapter $\mathrm{V}$ examines the implications and the heritage of the philosophers, especially in the educational sector. Both Socrates and Confucius have left great impacts on their own disciples. Moreover, the immeasurable and lasting effect of their educational philosophy on the 
Western and Chinese education traditions are also discussed. The learning cultures of China and most of the Western countries are as different as their respective philosophies and social life.

In the final chapter, the major findings of the study are summed up. This thesis will conclude with remarks concerning the contributions of the study. Limitations and suggestions for further research are proposed towards the end of the chapter. 


\section{CHAPTER II. LITERATURE REVIEW}

A. Philosophy and Philosophy of Education

Many scholars agree that the word 'philosophy' is derived from the Greek

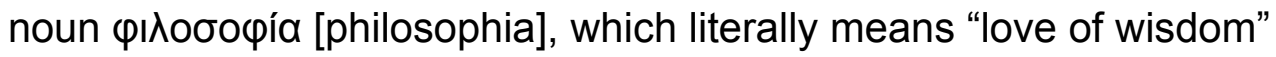
(Warburton, 2004, 1; Noddings, 2007, xiii). In its broad sense, philosophy is a study of general and fundamental problems such as the nature of existence, knowledge, morality, reason, and human purpose (Teichman and Evans, 1991, 1). According to Grayling, the aim of philosophical inquiry is normally abstract matters, such as to gain insight into questions about knowledge, truth, reason, reality, meaning, mind, and value $(1998,1)$. Warburton maintains that, the study of philosophy not only helps us to think clearly about our prejudices, but also helps to clarify precisely what we do believe $(2004,2)$. In the process it develops an ability to argue coherently on a wide range of issues. Its focus lies in the understanding of central concepts in the field, on revealing and examining assumptions, and on the critical analysis of arguments. Therefore, philosophy is "the human being's attempt to think speculatively, reflectively and systematically" (Teichman and Evans, 1991, 1).

According to The Oxford Companion to Philosophy, there are usually three components in philosophy - the general nature of the world (metaphysics or theory of existence), the justification of belief (epistemology or 
theory of knowledge), and the conduct of life (ethics or theory of value) (Quinton, 2005, 702). The area that philosophy of education is closely related to is epistemology, or theory of knowledge. Chambliss in the Philosophy of Education: An Encyclopaedia argues that the literature in philosophy of education, to a large extent, is coterminous with the literature of general philosophy $(1996,472)$. In his analysis, philosophy originated in ancient Greece under the pressure of questions about the nature of arete (meaning 'virtue'), which was traditionally to be held as a natural possession of the few-the "nobly born," as celebrated in the epics of Homer (c.850 B.C.E.) and the odes of Pindar (518-438 B.C.E.). In the dialogues of Plato, Socrates is portrayed asking questions like "can virtue be taught" and "what is the nature of virtue". These are matters of philosophy in that they are questions about the life worth living (ethics), knowing (epistemology), and the nature of reality (metaphysics). And at the same time they are matters of education, because answers to these questions can be found only in an educational process that aims to find out the nature of virtue. Thus, questions such as what is worth knowing and how we can know it have both a philosophical and an educational dimension $(1996,461)$. Chambliss concludes that "it is clear that, in their origins, philosophy and educational theory stood on common ground" (1996, 461); and that "philosophy of education, like philosophy in other contexts, beginning in curiosity about the nature of things, is thinking about what to do in education" (1996, 462). The ancient Greeks did not use the term philosophy of education in their writings. Yet they first envisaged what later thinkers came to philosophy of education. 
In the current Routledge International Companion to Education, philosophy of education is defined as "philosophy in relation to educational concerns" (Burbules, 2000, 5). It is the reasoned inquiry into the nature of education and it should also be pointed out that now the boundaries of philosophy of education are being stretched and blurred. The Cambridge Dictionary of Philosophy even defines it as broadly as a branch of philosophy concerned with virtually every aspect of the educational enterprise" (Senchuk, 1995, 670); and it embraces work across a wide range such as ideas, practices and policies relevant to education (White, 2008, 434).

\section{B. Socrates}

\section{Life of Socrates (469 - 399 B.C.E.)}

Interestingly enough, we know how Socrates looked. He is the first philosopher to stand before us in the flesh. He was a robust man with great powers of physical endurance. In his playful comedy, The Clouds, Aristophanes depicted Socrates as a strutting waterfowl, poking fun at his habit of rolling his eyes. Socrates was short, stout, ungainly, snub-nosed and ugly, not at all the image of the dignified philosopher that has come down to us. Plato confirmed this general portrait and in addition pictured Socrates as a man with a deep sense of mission and moral purity.

Socrates grew up in the powerful and prosperous Athens. According to Plato, Socrates' father was Sophroniscus, a stonemason and his mother Phaenarete, a midwife. Almost nothing was known of the childhood of Socrates but it could be assumed from his later display of learning that he 
attended the schools of Athens until he entered military service at age of eighteen.

In fulfillment of his military duties, he fought with distinction as a hoplite (a heavily-armed foot-soldier) in the Peloponnesian war. Several of Plato's dialogues referred to Socrates' military service. It was said that he served in the Athenian army during three campaigns: at Potidaea, Amphipolis, and Delium. In the Symposium Alcibiades described Socrates' valour in the battles of Potidaea and Delium, recounting how Socrates saved his life in the former battle (219e-221b). Socrates' exceptional service at Delium is also mentioned in the Laches, by the general the dialogue is named after (181b). In the Apology Socrates compared his military service to his courtroom troubles, and said that anyone on the jury who thought he ought to retreat from philosophy must also think that soldiers should retreat when it seemed like they would be killed in battle.

Back from the battles, Socrates was known as making a living as a stonemason, and he married Xanthippe, who was much younger than her husband. She bore him three sons, Lamprocles, Sophroniscus and Menexenus. In his life, the Greek philosopher had a reputation for being impervious to pleasures and hardships alike. He enjoyed good company, food and wine, but went about bare-footed and remained relatively poor (Howatson \& Sheffield, 2008, 86). Living frugally, he was materially independent, thanks to a small inheritance and the state subsidies that were paid out to all Athenians (theater fees and the like). Socrates was known as promoting the virtue of frugality and stressing a simplistic way of living. 
In many of the dialogues, Plato pictures Socrates loitering around schoolyards looking for people to talk. Also in Xenophon's Symposium, Socrates is reported as devoting himself only to what he regards as the most important art or occupation: discussing philosophy. In The Clouds, Aristophanes portrays Socrates as accepting payment for teaching and running a sophist school with Chaerephon, while in Plato's Apology and Symposium and in Xenophon's accounts, Socrates explicitly denies accepting payment for teaching. More specifically, in the Apology Socrates cites his poverty as proof that he is not a teacher.

In his life, Socrates experienced the decline and defeat of Athens. In Aristophanes' play of The Clouds, Socrates was portrayed as a godless charlatan who used his devious intelligence to swindle unsuspecting citizens. Aristophanes may not have believed that Socrates was in fact an atheist, but his portrayal of him as denying the existence of the traditional gods contributed to a prejudice among his fellow citizens that undoubtedly influenced the outcome of a trial that Socrates was subjected to.

In 399 B.C., for reasons that appeared to have been at least partly political, Socrates was prosecuted for impiety. In the restored democracy, Socrates was put on trial on the serious charge of corrupting the minds of the young and of believing in deities of his own invention instead of the gods recognized by the city (Xenophon, Memorabilia 1.1.1). At his trial, Socrates refused to employ a proper defense, choosing instead to make an uncompromising avowal of his life's aims and endeavors, which was recorded in Plato's Apology. In his speech, Socrates tried to dismiss rumors that he was a sophist and defended himself against charges of disbelief in the gods and 
corruption of the young. Socrates insisted that long-standing slander would be the real cause of his demise, and said the legal charges were essentially false.

Condemned to death after his conviction by 281 votes to 220 , he refused the opportunity to have his sentence commuted to a heavy fine, but chose to drink a brew of poison hemlock, which he did in the company of his students. The event was also documented in Plato's Apology.

\section{Philosophy of Socrates and Socratic Education Philosophy}

Socrates has been regarded as the philosopher who "brought philosophy down from the skies," familiar to us from Cicero ${ }^{2}$. For the Greeks themselves, the name of Socrates formed a watershed in the history of their philosophy. The reason they gave for this was that it was Socrates who turned men's eyes from the speculations about the nature of the physical world which had been characteristic of the Presocratic period, and concentrated attention on the problems of human life. In the most general terms, his message was that to investigate the origin and ultimate matter of the universe, the composition and motions of the heavenly bodies, the shape of the earth or the causes of natural growth and decay was of far less importance than to understand what it meant to be a human being and for what purpose one was in the world (Cooper, 2005, 968). Its popularity has made it, whatever its historical basis, an important element in the history of thought.

The origin of Socrates' philosophy was from Plato's Apology, in which Chaerophon, one friend of Socrates, had consulted the oracle at Delphi to ask

\footnotetext{
2 After speaking of Pythagoras, Cicero says:

"Socrates, however, called philosophy down from heaven and placed it in the midst of our cities, even introduced it into our homes, and forced it to ask questions about our life, morals, and the good and band in things.." (Tusc. 5. 4.10, quoted from Gill, M. L\& Pellegrin P., 2009, 170).
} 
whether there was any one wiser than Socrates. The oracle replied 'No.' Dumbfounded at this, Socrates set out to refute the oracle by seeking out those with reputations for wisdom, the philosophers, poets and artists, only to find that they knew nothing at all, but, unlike Socrates, did not recognize their own ignorance (Sowerby, 2009, 144). Thereafter the Greek philosopher considered it his duty to disabuse all sorts and conditions of men of their own self-conceit and their own self-ignorance, and so put them on the road to truth.

Socrates was and remains one of the most influential figures in the history of Western philosophy. Socrates himself never wrote any of his ideas down, but rather engaged his students, the wealthy young men of Athens, in endless conversations. Socrates was interested in ethics, conducts of life, and moral truth, or the higher ends in what one must do to be good. He pursued his general definition in dialogue with others, and devoted to asking and thinking about those most important matters. He called that way of life "philosophy." Socrates' life was depicted in The Cambridge Dictionary of Philosophy as a philosopher whose daily occupation was "adversarial public conversation with anyone willing to argue with him" $(1995,859)$. Socrates talked in public-in the market place, outside the gymnasium, at parties, or wherever he happened to be. Moreover, he would talk philosophy with virtually anyone-fellow philosophers or sophists, public figures, playwrights, rich people or poor people, adults or children, and even slaves.

Socrates used the question-and-answer technique in his search for true knowledge. He would begin with a deceptively simple question such as "What is truth?" Or, "What does it mean to be just?" When the other person answered, Socrates responded with another question that prompted him or her to think 
more deeply so as to offer a new answer. ${ }^{3}$ By engaging in repeated questioning, Socrates revealed some seemingly true knowledge in many people was actually false and he also exposed the foolishness of the respected men. Such a strategy used by Socrates, which came to be known as the Socratic Method, has been regarded as perhaps one of the earliest teaching strategies ever described in education history (Miller, 2008, 963). This method involved cross-questioning; for this he pretended to be ignorant in order to draw out and refute an opponent. The Greek word for this kind of pretence is eironeia and this questioning method is called Socratic irony (see the Republic 337a). The refutation is generally called the elenchos. By destroying the conceit that we already have knowledge, the elenchos is negative in effect, destructive of self-ignorance, conventional beliefs and received opinions: the effect of it is perplexity or impasse, aporia in Greek (Sowerby 2009, 144). His conversation partners were often forced into the unpleasant experience of realizing their own ignorance. Still used today as a teaching strategy, the Socratic Method is a dialectic method of teaching that "involves dialogue and questioning, emphasizing the exchange of ideas and suppositions that then transforms knowledge itself' (Miller, 2008, 963). The aim of Socratic questioning was not to test or assess, but to draw out the other people's inner tacit knowledge and progress towards the truth.

According to Plato and Xenophon, Socrates adamantly insisted he was not a teacher and refused all his life to take money for what he did. He said that he did not teach, but rather served as a midwife to truth that is already in us. Socrates believed that we unfortunately lose touch with that knowledge at

\footnotetext{
${ }^{3}$ This process is recorded with details in Noddings (2007, 3-4).
} 
every birth, and so, rather than learning something new, we need to be reminded of what we already know. Thus, making use of questions and answers to remind his students of knowledge is called maieutics (midwifery). Another famous metaphor about his service to philosophy was that he claimed to have performed for the Athenian people as a gadfly which provoked and stung them into fresh activity. Yet much of his influence was due not to anything that he said at all, but to the magnetic effect of his personality and the example of his life and death, to the consistency and integrity with which he followed his own conscience rather than adopting any belief or legal enactment simply because it was accepted or enjoined (Guthrie, 1971, 127).

In Gary Alan Scott's Plato's Socrates as Educator, the model of Socratic education implicit in the dialogues is described as the "integrative" model $(2000,41)$. With the integrative model of education, new knowledge is thought to be substituted for, or integrated with old knowledge or belief in such a way that both the content and form of one's knowledge might be said to be fundamentally reconstituted. With this model, the incompatibilities and inconsistencies in the various beliefs and opinions one holds must be reconciled, and some of them must perhaps be discarded before new ideas can be appropriated or assimilated to the old. Here one's knowledge must be thoroughly reformulated, reconstituted, or reconfigured, with as much attention to its form as to its content (Scott, 2000, 41). In many of the "What is X?" dialogues, for example, the philosopher's interlocutors do not so much learn a new definition of $\mathrm{X}$ as they learn what kind of answer would be adequate as a definition of any term such as $\mathrm{X}$. 


\section{Confucius}

\section{Life of Confucius (551 - 479 B.C.E.)}

Confucius actually was the Latinized name for the ancient Chinese philosopher named Kong Qiu ${ }^{4}$ in which $\mathrm{Kong}^{5}$ was the family name, Qiu ${ }^{6}$ was the given name, and his cognomen was Zhongni ${ }^{7}$. He has been often revered as Kong Fuzi ${ }^{8}$ in Chinese, with $\mathrm{Fuzi}^{9}$ meaning "the master". Confucius lived from 551 to 479 B.C.E., in the final years of what is called the Spring and Autumn Period (770-476 B.C.E.) and just before the beginning of the Warring States (475-221 B.C.E.).

Confucius was born and died in the state of $L u^{10}$ in the Northeast of China. His father was once a city mayor and a man of great strength and courage. His mother was recorded to be of good character, and appeared to have stimulated his ambition and encouraged his studies ( $\mathrm{Li} \mathrm{Ji}$, or The Book of Rites, Bk. 2, Sec. 1, pt. 1). He lost his father at the age of three and grew up in straitened circumstances, under his mother's care. As a boy he liked to play making sacrificial offerings and performing the ceremonies (Chen, 1990, 111). At the age of nineteen he married, and a son and two daughters were born to him. Also in the same year, Confucius entered upon his official career in $\mathrm{Lu}$, being first a keeper of grain stores and then in charge of public lands (Mencius $5,2,5)$. Then, later he held some minor official positions, advising kings and rulers and took on a number of disciples. Around the year of 518 B.C.E., 
Confucius went to visit and seek advice from Laozi, a renowned Chinese philosopher. After he returned to the state of $\mathrm{Lu}$, "more and more disciples came to study under him" (Shiji, or Records of the Grand Historian). Confucius edited the Book of Poetry and the Book of History, compiled the book of The Book of Rites and the Book of Music, annotated the Book of Changes, and wrote the Spring and Autumn Annals. In order to realize his political propositions, Confucius kept on fighting for the restoring of the ideal social order in spite of all setbacks. At the age of 56, in the company of his disciples, Confucius left the state of $\mathrm{Lu}$, and began his 13 years of wandering life among the different states (496-484 B.C.E.), teaching his disciples and preaching his doctrines. He underwent hardships and dangers staying in one state and then in another (Chen, 1990, 113). In all his life, Confucius advocated restoring traditional values and norms as a remedy for the social and political disorder of his times, and sought political office in order to put this ideal into practice. However, eventually he did not attain any influential position in government. Many of the legends surrounding Confucius were included by the Han dynasty court historian, Sima Qian ${ }^{11}$ (145-c.85 B.C.E.), in his well-known and often-quoted Records of the Grand Historian (Shiji ${ }^{12}$ ). Confucius died in 479 B.C.E. when he was at the age of 73 . He was buried by the Sishui ${ }^{13}$ River in the north of Qufu ${ }^{14}$ City of Shandong, where the cemetery of Confucius is today.

\footnotetext{
11 司马迁

12 《史记》

13 泗水

14 曲阜
} 


\section{Philosophy of Confucius and Confucian Education Philosophy}

Like Socrates, Confucius did not write much during his lifetime; and we could only learn about him from the records of his disciples, particularly from the Analects.

During those feudal times, there was a complete lack of law in the society and feudal wars were prevalent. Appalled by this state of affairs Confucius tried to restore ancient principles. Confucius offered new social patterns which were the fundamentals of human nature, values, and also ethics, etc. The overwhelming concern of Confucius was the relation of the human being to other human beings and a set of ethical ideas oriented toward practice. Therefore, Confucius taught a system of ethics including loyalty, filial piety, benevolence, righteousness, honesty, etc. The major concepts involved were $\operatorname{ren}^{15}$ (human-heartedness), $/ i^{16}$ (the rites or observing ritual propriety), and junzi ${ }^{17}$ (an exemplary person). He also taught his students proper speech, government, and the refined arts.

At the heart of his teaching was 'ren', usually translated as goodness or benevolence, which was Confucius' central doctrine of the "the primacy of the human heart". Confucius called for a lifelong pursuit of love or humanheartedness, a personal cultivation that involved achieving inner equanimity and outer integrity and responsibility to society. Confucius also taught the importance of courtesy and moderation in all things. These were included in the concept of $l i$, which means the rites, proprieties, good manners and politeness, and lead ultimately to harmony and order, which were

\footnotetext{
15 仁

16 礼

17 君子
} 
Confucius' goals. In the philosophy of Confucius, li involves the deliberate devices used by the sages to educate people and maintain social order. This has been explained very clearly in the book of $\mathrm{Li} \mathrm{Ji}{ }^{18}$, The Book of Rites, in which it becomes clear that li has a prescriptive and regulative function (Guthrie, 1971, 168).

Confucius taught that everybody should accept their role in life and duties towards others, and the system was hierarchical. One had clear obligations toward the other in the relationship pairs. Rulers had a duty to be benevolent while subjects should be respectful and obedient. Children should honor their parents and parents should take good care of their children. In short, he aimed to establish a world of great harmony. He proposed the syncretism of nature and human beings, and suggested that people live harmoniously with nature.

While Confucius regarded morality as the most important subject, he also emphasized the "Six Arts" — ritual, music, archery, chariot-riding, calligraphy, and computation. Confucius' goal was to create gentlemen who could carry themselves with grace, speak correctly, and demonstrate integrity in all things. He was thought to have had a role in collating what were known as the Six Classics -Book of Poetry, Book of History, The Book of Rites, Book of Music, Book of Changes, and the Spring and Autumn Annals.

In terms of education, it was recorded in the Analects that Confucius was willing to teach anyone, whatever their social standing, as long as they were eager to learn. The principle of "providing education for all people without discrimination" was first proposed by Confucius in the ancient China and he 
advocated that anyone, rich or poor, was entitled to education from him. Confucius' private school has been extolled as an institution which brought access to learning, a privilege previously enjoyed by aristocrats, to the general public; and the students who had conversations with Confucius as identified in the Analects came from various social backgrounds (Shen, 2001, 2). During his lifetime, the private school he established had enrolled about 3,000 students, 72 of whom were outstanding ones.

As for teaching method, Confucius adopted the approach of "educating someone according to his natural ability" and "heuristic education". What he often cited in his speech was passages from the classics, and he frequently used analogies. Confucius attached high importance on efforts and the love of learning, as he was such a scholar himself. To a disciple whom a prince has questioned about him, Confucius says: "Why did you not answer thus: He (Confucius) is a man who learns the truth without tiring, who instructs men indefatigably, who is so zealous that he forgets to eat, who is so serene that he forgets all cares, and consequently does not notice the gradual approach of old age $^{19 "}$ (The Analects, Bk. VII, Ch. X IX).

Confucius represented his teachings as lessons transmitted from antiquity. He claimed that he was "a transmitter and not a maker" and that all he did reflected his "reliance on and love for the ancients" ${ }^{20}$ (The Analects, Bk. VII, Ch. I.). For the Chinese philosopher, learning was viewed as a process by which individuals' minds acquire what is out there; and education is taken in

\footnotetext{
19 叶公问孔子于子路, 子路不对。子曰: “女奚不曰, 其为人也, 发愤忘食, 乐以忘忧, 不知 老之将至云尔。”《论语 述而第七: 十九》

${ }^{20}$ The Master said, "A transmitter and not a maker, believing in and loving the ancients, I venture to compare myself with our old Peng” (Analects, Bk. VII, Ch. I.) (子曰: “述而不作, 信而好古, 窃比于我老彭。”《论语 述 而第七・ 一》)
} 
terms of cultural transmission, service to society, and moral transformation. Therefore, the Confucian teaching model may be described as in the model of "knowledge-transfer." On the "knowledge-transfer" model, knowledge is presumed to transfer from the one who has it to the one who does not. The "knowledge-transfer" model assumes that learning is defined by an increase in the sum of the factual information at one's disposal; and so, from this view, new information is merely added to whatever knowledge one previously had, like new data is added to a data bank or inventory is added to a warehouse (Scott, 2000, 40).

\section{Previous Studies on Socratic and Confucian Education Theories}

There have been studies on comparing Socratic and Confucian teaching theories, but, as they sprang from different perspectives, the findings are not the same. Among them, Li, Tweed and Lehman, and Gurung are best representatives. Jin Li treats Socratic and Confucian learning models on the same epistemological basis and argues that the differences lay merely in their approaches (2002: 146-147). Considering culture-influenced aspects of academic learning, Roger G. Tweed and Darrin R. Lehman analyze the Confucian-Socratic framework based on their epistemological differences and contrastive approaches. According to them, while Socrates valued questioning of widely accepted knowledge and expected students to generate and consider their own hypotheses, Confucius valued effortful, respectful, absorptive, and pragmatic learning (Tweed and Lehman, 2002, 89-99). Regan Gurung places the Confucian-Socratic framework within the context of prior theory on education and epistemological development and suggests that 
cultural-level analyses of Confucian and Socratic tendencies will be less fruitful than individual-level analyses. Gurung maintains that as in many areas of psychology study, there is often higher within-culture than cross-cultural variance in learning style. "The consideration of individual differences in ways of knowing, merging educational theory with this new cultural dichotomy in learning, makes for a more powerful heuristic tool for educational reform and the scholarship of teaching" (Gurung, 2003, 146).

These are very important efforts in investigating Socratic and Confucian philosophy of education, and some of them draw valuable conclusions such as both Western and Asian learners could benefit from each other' intellectual tradition (e.g. Li Jin, 2003, 146). But due to limited existing literature and studies on Confucius in the Western academia, partial knowledge or even some misunderstandings may arise about this Chinese ancient philosopher. For example, in describing the teaching methods of Confucius similar phrases appear so frequently as 'dogmatic' (Beck, 2006, 138), "rote learning and memorization of facts" (Aoki, 2006, 37), "passive transmission and uncritical assimilation of knowledge" (Forrester, Motteram and Liu, 2006, 209), or even "authoritarian" (Forrester, Motteram and Liu, 2006, 209). At the same time, some studies tend to exalt Confucius to another extreme, which are often described euphuistically with "greatness", "the greatest sage", "role model for teachers through the ages", "the sage master of all ages", "the ultimate sage master" (Chen, 1990, 13-14, Yao, 2000, 56, etc.). In fact, in the Analects, Confucius himself was humble to describe himself as "a transmitter and not an originator, believing in and loving ancient studies" (The Analects, Bk. VII, Ch. I.). 


\section{E. Explanations on Terminology}

\section{The Concepts of Teaching and Learning}

"Teaching" is a broad, general term, and it may encompass a wide variety of more specific activities such as lecturing, instructing, drilling, eliciting responses, asking questions, testing, encouraging, and providing information (Barrow \& Milburn, 1990, 306). In The Routledge International Encyclopaedia of Education, teaching is described as "the process of educating or instructing learners" (Crook, 2008, 589) and it is sometimes represented as an art, which is shaped by the teacher's attitudes, values, knowledge, assumptions and ways of doing things. And on the other hand, learning is defined as "a change in someone's behavior, knowledge, level of skill, or understanding which is long-lasting or permanent and is acquired through experiences rather than through the process of growth or ageing" (Channing \& Aubrey, 2008, 157). Traditionally, learning is regarded as an internal process of acquisition, and its process is influenced by learners' wide differences in motives, aptitudes, abilities, propensities and background knowledge (Desforges, 2000, 79). Philosophers have tried various ways of viewing teaching and learning in the attempt to get the relationship between them clear. Teaching and learning are thought to be closely related to epistemology, or knowing, and to logic, the correct patterns of thinking (Gutek, 2009, 9).

\section{The Working Definitions of the West and the East}

The terms "the West" and "the East" as cultural labels could be problematic (Lillard, 1998, 7) because literally they denote the Western and the 
Eastern hemisphere, thereby including different people than is usually implied by the use of the two categories as described in cultural matters. Rather than using terms like "European American," which excludes, for example, Canadians and Australians, we retain the shorthand term "the West". In this paper, the term "the West" largely refers to Europe and the United States, which found their origin in the ancient Greek and Roman culture and the term "the East", Northeast Asian countries, especially China, Japan, and Korea, which are under the impact of Sinitic cultures.

\section{Culture \& Cultures of Teaching and Learning}

\section{a. Culture}

Culture is empirically a multi-faceted concept. In anthropology, different cultures have developed different concepts of responsibility, self and understanding (Markus \& Kitayama, 1991, 239). Hofstede (1997) defines culture as the collective programming of the mind which distinguishes the members of one human group from another. In terms of cognitive science, culture also provides the cognitive terms for individuals within a group and society preconditions for human behaviour (Gao and Schachler, 2004, 43; Solas and Ayhan, 2007, 151). Pusch $(1979,29)$ defines culture as "the sum of total ways of living, including values, beliefs, aesthetic standards, linguistic expression, patterns of thinking, behavioral norms, and styles of communication which a group of people has developed to assure its survival in a particular physical and human environment"; and this definition is used in the present study. 


\section{b. Collective versus Individual Orientation}

The discussion in the study is linked to the dimension of individualism-collectivism which has been widely used in cross-cultural studies to explain differences between cultural groups. According to Triandis et al. (1990, 1007), individualists tend to think of individuals as the basic unit of analysis. Individualists are mostly concerned about having the freedom to do their own thing. Certain values such as freedom, equality, creativity, bravery, independence and competition from the in-group are emphasized in individualistic cultures (Triandis et al. 1990, 1008). Individualists have in-groups and out-groups, but they do not see as sharp a contrast between them and do not behave as differently toward in-group and out-group members as collectivists do.

In contrast, collectivists tend to think of groups as the basic unit of analysis of society (Triandis et al., 1990, 1008). The tendency to think of groups as the units of analysis will result in in-groups being perceived as more homogeneous than out-groups in collectivist cultures. This tendency will become even stronger in collectivist cultures because the emphasis on in-group harmony requires in-group members to conform and to be homogeneous. In collectivist cultures behavior is regulated largely by in-group norms, which are more important determinants of social behavior. Furthermore, harmony is an important attribute in collectivist cultures. The in-group is supposed to be homogeneous in opinion, and no disagreements should be known to out-groups. Thus, hierarchy and harmony are important defining attributes of collectivists (Triandis et al., 1990, 1007). With regard to values, collectivist cultures stress social recognition, loyalty, tradition, being humble, 
honoring parents and elders, obedience to authority and proper behavior as key values.

\section{c. Cultures of Teaching and Learning}

Cultures of teaching and learning are set within taken-for-granted frameworks of expectations, attitudes, values and beliefs about how to teach or learn successfully, encompassing expectations of classroom structure and behavior. Cultural variables such as philosophical perspectives, value orientation, and motivation have an impact on teaching and learning; and how they are perceived. As such they reflect the dominant cultures they exist in; and teachers and students are expected to operate within their implicit rules and customs, whilst 'other' behaviors or indeed models of learning may be rejected as inferior or primitive (Gudykunst 1998; Cortazzi \& Jin, 1996).

Learning as a universal human activity has been approached from a great many perspectives, and teaching and learning styles have been under intense investigation as well. However, the role of culture is far from being fully understood. Culture provides tools and habits that pervasively influence human thought and behavior and virtually no one can escape this influence (refer to Tweed and Lehman 2002; Brislin, Bochner, \& Lonner, 1975; Bruner, 1996; Greenfield, 1997). As a result, Socratic and Confucian philosophies, especially their educational philosophies, are, to a large extent, culturally constructed. They are the product of their respective historical, social and cultural climate. And reversely, their thoughts have greatly impacted and shaped their own culture. In the light of limited studies on Socrates and Confucius from the cultural perspectives, this paper, therefore, is an attempt to 
investigate the social and cultural traits in Socrates and Confucius' philosophy of education, and examine their impacts on the later educational development in both cultures.

\section{F. Summary}

In Chapter II, the theoretical framework used in the study is presented. First, the author identifies the definition of philosophy, and philosophy of education, the theoretical framework that the present study employs. The literal meaning of 'philosophy' is "love of wisdom". Broadly, philosophy could be defined as a study of general and fundamental problems such as the nature of existence, knowledge, morality, reason, and human purpose. Philosophy of education is close to epistemology, or theory of knowledge, a component of philosophy; and it concerns with virtually every aspect of the educational enterprise.

The definition of the basic concepts is followed with an overview of the life and thoughts of Socrates and Confucius so as to help readers to better understand the two philosophers. Son of a sculptor and a midwife, Socrates had military service in his youth. Leading a frugal and self-controlled life, Socrates was reported to devote himself only to what he regarded as the most important art or occupation: discussing philosophy. Socrates revealed that some seemingly true knowledge in many people was actually false and he also exposed the foolishness of the respected men. The elite, not surprisingly, resented Socrates, and eventually Socrates was accused and sentenced to death for not believing in the state's gods and corrupting the youth of Athens. What we now know of Socrates comes entirely from the writing of his 
disciples—chief among them Plato. And the early dialogues of Plato are thought to be the most representative of Socrates' thought (Cooper, 2005, 970; Curren, 2007, 8). The earlier philosophers were collectively known as the Presocratics, because with Socrates philosophy took a new direction: philosophy moved from physics to ethics. Like many Athenians, Socrates spent his life in the streets, the market places, or at banquets. It was a life of conversation with everyone. Socrates used the question-and-answer technique in his search for true knowledge. Such a strategy used by Socrates, which came to be known as the Socratic Method, has been regarded as perhaps one of the earliest teaching strategies ever described in education history.

Confucius lived in the final years of what is called the Spring and Autumn Period. In order to realize his political propositions, Confucius kept on fighting for the restoring of the ideal social order in spite of all setbacks. At the age of 55, leading his disciples, he went on a lobbying tour in various states to promote his political beliefs. Appalled by this state of chaos, Confucius offered new social patterns which were the fundamentals of human nature, values, and also ethics, etc. Like Socrates, Confucius did not write much during his lifetime; and we could only learn about him from the recordings of his disciples, particularly from the Analects. At the heart of his teaching was 'ren'. Confucius called for a lifelong pursuit of love or human-heartedness, a personal cultivation that involved achieving inner equanimity and outer integrity and responsibility to society. Confucius also taught the importance of courtesy and moderation in all things. These were included in the concept of $l i$, which means rites, proprieties, good manners and politeness, and lead ultimately to 
harmony and order, which were Confucius' goals. He also taught his students proper speech, government, and the refined arts. In education, Confucius attached high importance on efforts and the love of learning. For the Chinese philosopher, learning is viewed as a process by which individuals' minds acquire what is out there; and education is taken in terms of cultural transmission, service to society, and moral transformation.

After the description of the two important philosophers, the strength and weakness of the previous studies on Socrates and Confucius' educational philosophy and pedagogical methods are discussed. In the end of Chapter II, the author presents an overview of the related terminologies, i.e. the concepts of teaching and learning, and the working definition of the West and the East, the definition of culture and cultures of teaching and learning, setting the theoretical preliminaries of the following research and analysis. There are certain traits and differences in the individualistic and collectivist cultures. Cultural variables such as philosophical perspectives, value orientation, and motivation have an impact on teaching and learning. As a result, Socratic and Confucian philosophies, especially their educational philosophies are, to a large extent, culturally constructed. In the light of limited studies on Socrates and Confucius from the cultural perspectives, this paper, therefore, is an attempt to investigate the social and cultural traits in Socrates and Confucius' philosophy of education, and examine their impacts on the later educational development in both cultures. 


\section{CHAPTER III. HISTORICAL AND CULTURAL}

\section{CONTEXTS}

This chapter reveals the respective historical, social and cultural contexts in Ancient Greece and ancient China, and traces the fundamental cultural elements in the formation of Socratic and Confucian philosophical thoughts based on the political, social, and economic systems, and the evidence found in the artifacts of ancient Greek and Chinese philosophy, literature, and arts etc. before and while the two philosopher, Socrates and Confucius, lived.

\section{A. Athenian Society in the 4-6th Centuries B.C.E.}

\section{Historical and Social Background}

In Greek history, Ancient Greece was often viewed as the period of Greek history lasting from the Greek Dark Ages ca. 1100 B.C.E. and the Dorian invasion, to 146 B.C.E. and the Roman conquest of Greece.

In terms of geography, the territory of Greece was divided and sub-divided by hills, mountains and rivers, and hence, ancient Greece consisted of many smaller regions each with its own dialect, cultural characteristics, and identity. In his book A History of the Greek City States, Raphael Sealey $(1976,11)$ gives account of these numerous small self-governing communities which were mainly dictated by fragmentary Greek 
geography where every island, valley and plain was cut off from its neighbors by the sea or mountain ranges. Several hundred more or less independent city-states (poleis) were located in valleys between mountains or on coastal plains, and dominated a certain area around them. Regionalism and regional conflicts were the prominent feature of ancient Greece. This fragmentary geographical nature of ancient Greece contributed to its unique cultural traits. While the ancient Greeks had no doubt that they were "one people"-they had the same religion, same language and same basic culture; the Greeks were very aware of their tribal origins ${ }^{21}$. Great importance was attached to the independence of the poleis, and it was fiercely defended, whereas unification was rarely contemplated.

In the history of the Ancient Greece was the period of Classical Greece, which flourished during the fifth to fourth centuries B.C.E. By the sixth century B.C several cities had emerged as dominant in Greek affairs: Athens, Sparta, Corinth, and Thebes. Each occupied the surrounding rural areas and smaller towns. Among them, Athens, centered upon the Aegean and secured by the navy, had become one of the major maritime and mercantile powers.

\section{War and peace}

Classical Greece began with the repelling of a Persian invasion by Athenian leadership. A series of conflicts between the Greeks and the Persians began in the early fifth century B.C, starting with the unsuccessful Ionian Revolt, continuing with the spectacular Athenian victory over Persian

\footnotetext{
${ }^{21}$ In his work Histories, the historian Herodotus extensively categorized the ancient Greek city-states by tribes.
} 
forces at Marathon, and concluding with the final defeat of the Persians at sea at the battle of Salamis and on land at the battle of Plataea.

The two Greek poleis that had played the significant role in the defeat of Persia were Athens and Sparta. While Athens was a progressive, democratic city with the largest navy in the Greek world, Sparta was a conservative oligarchy, as noted in Sansone $(2009,123)$, with strong infantry who imposed on the slaves a rigorous system of physical training and institutional control aimed at maintaining their authority over a very large, servile population. Athens and Sparta became allies in the face of the largest external threat that ancient Greece had until the Roman conquest. After suppressing the Ionian Revolt, a rebellion of the Greek cities of Ionia, Darius I of Persia, King of the Achaemenid Empire, decided to subjugate Greece. His invasion in 490 B.C.E. was ended by the Athenian victory at the Battle of Marathon under Miltiades the Younger.

In the course of the fifth century B.C.E., the naval alliance of which Athens had become the leader, the so-called Delian League, in effect turned into an Athenian empire. The policy of the Athenian democracy in the mid-fifth-century B.C.E. was expansionist (Sansone, 2009, 52). The dominant position of the maritime Athenian 'Empire' and its aggressive and self-assertive growth of power since the Persian Wars threatened Sparta and the Peloponnesian League of mainland Greek cities. Inevitably, Athenian ambitions on land brought Athens into conflict with Sparta. In 460 Athens made an alliance with Argos and in 459, Megara, strategically situated on the northern side of the isthmus of Corinth, withdrew from the Peloponnesian League to make an alliance with Athens. The Athenians intervened in conflicts 
between states north of the isthmus, but did not have the military means to sustain their power on land, so that, after fifteen years of intermittent hostilities, the Thirty Years Peace treaty was signed between Sparta and Athens in 446, in which Athens gave up her ambitions on land in return for Spartan recognition of Athenian naval hegemony (Sowerby, 2009, 52).

The sudden reversals in attitude and policy in both Sparta and Athens in the fifty years after the Persian Wars were best explained by the likelihood of arguments within each state over the proper reaction to the actions of the other. After the break with Sparta in the Peloponnesian War (431- 404 B.C.E.), Athens suffered a number of setbacks. The Plague of Athens in 430 B.C.E. followed by a disastrous military campaign known as the Sicilian Expedition severely weakened Athens. An estimated one-third of Athenians died, including Pericles, their leader.

Our Greek philosopher, Socrates (469-399 B.C.E.), lived in such a time of great political unrest, during the time of the transition from the height of the Athenian hegemony to its decline with the defeat by Sparta and its allies in the Peloponnesian War. Athenian power was further weakened at the early fourth century B.C.E. The decisive moment came in 405 B.C.E. when Sparta cut off the grain supply to Athens from the Hellespont. Thus, the crippled Athenian fleet was decisively defeated by the Spartans. In 404 B.C.E. Athens sued for peace and Sparta dictated a predictably stern settlement: Athens lost her city walls (including the Long Walls), her fleet, and all of her overseas possessions. As a result, the Classical Period dominated by Athens and the Delian League during the fifth century was displaced by Spartan hegemony during the early fourth century B.C.E. But it was not long before the power again shifted to 
Thebes and the Boeotian League and finally to the League of Corinth led by Macedon. Because of conquests by Alexander the Great, classical culture of the poleis turned towards the flourishing of Hellenistic culture (323-146 B.C.E.) which began with the death of Alexander (323 B.C.E.) and ended with the Roman conquest.

From 497-338 B.C.E., Athens was at war for three years out of four, and Greek states in general regarded periods of peace more as respite from inevitable wars. In the fifth century 'truces' were made for limited periods only. Sparta and Athens, for instance, made a thirty-year peace in 446 B.C.E. In the fourth century B.C.E. dreams of a more abiding state of peace found expression in talk of 'peace', and the so-called Common Peaces, made to ensure peace and goodwill amongst all the Greeks, had no time limits. But the dreams were vain. In 375 B.C.E., to express jubilation over the end of hostilities with Sparta, the Athenians erected an altar to peace, and every year from then on there were sacrifices made to this abstract deity. However, by 373 B.C.E. they were at war again. In brief, wars were central to Greek life.

\section{Ancient Greek Economy and Social Structure}

In this period, huge economic development occurred in Greece and also in her overseas colonies which experienced a growth in commerce and manufacturing. There was a large improvement in the living standards of the population. Some studies estimate that the average size of the Greek household, in the period from 800 B.C.E. to 300 B.C.E., increased five times, which indicates a large increase in the average income of the population. At its economic height, in the fifth and fourth centuries B.C.E., ancient Greece was 
the most advanced economy in the world. According to some economic historians (e.g. Schieder, 2005), it was one of the most advanced preindustrial economies. This is demonstrated by the average daily wage of the Greek worker which was, in terms of wheat, about $12 \mathrm{~kg}$. This was more than 3 times the average daily wage of an Egyptian worker during the Roman period, about $3.75 \mathrm{~kg}$ (Schieder, 2005, 35).

Starting from the bottom, people in the Athenian society were divided into slaves, freedmen, metics, and citizens who were further subdivided into thetes (the fourth class citizen, i.e. the urban craftsmen and trireme rowers), hoplites (the third class citizen, i.e. mostly farmers who could afford infantry armor), knights (the second class citizen, i.e. aristocracy, traditionally defined as people who could afford to maintain war horses) and pentakosiomedemnoi (the first class citizen, i.e. super-wealthy citizens who could contribute to the city's defence by donating warships).

At the very bottom of this social ladder, slaves had no power or status. They had the right to have a family and own property, subject to their master's goodwill and permission, but they had no political rights. By 600 B.C.E. chattel slavery had spread in Greece. By the 5th century B.C.E. slaves made up one-third of the total population in some city-states. About two-fifths of the population of Classical Athens or more were slaves. City-states legally owned slaves. These public slaves had a larger measure of independence than slaves owned by families, living on their own and performing specialized tasks. In Athens, public slaves were trained to look out for counterfeit coinage, while temple slaves acted as servants of the temple's deity and Scythian slaves were employed in Athens as a police force corralling citizens to political 
functions. Most families owned slaves as household servants and laborers, and even poor families might have owned a few slaves. Owners were not allowed to beat or kill their slaves. Owners often promised to free slaves in the future to encourage them to work hard. Slaves outside of Sparta almost never revolted because they were made up of too many nationalities and were too scattered to organize.

Freedmen was treated better than the slaves, however, they did not become citizens. Instead, they were mixed into the population of metics, which included people from foreign countries or other city-states who were officially allowed to live in the state. Only the free, land owning, native-born men could be citizens who were entitled to the full protection of the law in a city-state ${ }^{22}$. However, non-citizens, such as metics (foreigners living in Athens) or slaves, had no political rights at all.

The upper class in the society was the aristocracy in power. Yet, in most Greek city-states, social prominence did not allow special rights. In Athens, The different social classes were divided based on wealth. People could change classes if they made more money. With the boosting of the ancient Greek economy, a mercantile class rose from the first half of the seventh century, by the introduction of coinage in about 680 B.C.E. The aristocratic regimes which generally governed the poleis were threatened by the new-found wealth of merchants, who in turn desired political power. From 650 B.C.E. onwards, the aristocracies had to fight not to be overthrown and replaced by populist tyrants ${ }^{23}$.

\footnotetext{
${ }^{22}$ Later Pericles introduced exceptions to the native-born restriction.

${ }^{23}$ The word derives from the non-pejorative Greek $\tau$ v́ $\alpha v v o \varsigma$ tyrannos, meaning "illegitimate ruler", although this was applicable to both good and bad leaders alike (Online Etymology Dictionary).
} 
In Sparta, the social structure was somewhat simpler. Starting from the bottom, there were helots (slaves), Perioeci, or craftsmen who were subject to taxation and occasional military service, but had no political rights; Spartiates or Homoioi (equals), a class of military professionals, and the two Kings, who were considered Homoioi as well. Sparta had a special type of slaves called helots, who were Messenians enslaved during the Messenian Wars by the state and assigned to families where they were forced to stay. Helots farmed and laboured for Sparta, so that Spartan women could concentrate on raising strong children while Spartan male citizen could devote their time to training as hoplites, i.e. soldiers of the Spartan Army in a permanently militarized state. The masters of the helots treated them so harshly that it was said that every Spartiate male had to kill a helot to show his bravery and maturity, and helots often resorted to slave rebellions.

\section{Government-from Aristocracy to Tyranny}

The government of most Greek states lay in the hands of aristocracies of one sort or another. Throughout the classical period and after, the characteristic form of government was oligarchy based on wealth and birth. It was recorded in The World of Athens $(1984,5)$ that the increasing wealth of the communities at that time was, in part, distributed among men who were outside the ruling aristocracies and came to resent their lack of influence. The adoption of weapons and tactics of the heavy-armed hoplites brought men

together to train and march. A spirit of comradeship was inspired and, with it, a growing awareness of the armed citizens' potential power. In many communities over the next century or more, there emerged a man, resentful at 
exclusion from power, who exploited the discontents and the military might of the citizens to seize personal power ${ }^{24}$. Such a usurper was known as a turannos ('tyrant') — the word, as discussed above, did not necessarily carry with it implications of cruelty or oppression.

In the second half of the sixth century, Athens fell under the tyranny of Peisistratos. In 561/0, Peisistratos, a military hero, whipped up popular support and took over Athens as tyrant. His control was far from absolute. Twice he was thrown out by his political enemies. Twice he made a comeback. In 546 he consolidated the tyranny at Athens and from then on managed to remain in power until his death in 528/7. Then his sons Hippias and Hipparchos took power.

\section{The Birth and Development of Democracy}

In 510 B.C.E., at the instigation of the Athenian aristocrat Cleisthenes, the Spartan king Cleomenes I helped the Athenians overthrow the tyranny. Afterwards, Sparta and Athens promptly turned on each other, at which point Cleomenes I installed Isagoras as a pro-Spartan archon. In order to prevent Athens from becoming a Spartan puppet, Cleisthenes responded by proposing to his fellow citizens that Athens undergo a revolution in which all citizens shared in political power, regardless of status. Thus Athens became democratic. The Athenians readily took this idea, and after that having overthrown Isagoras and implemented Cleisthenes' reforms, they were easily able to repel a Spartan-led three-pronged invasion aimed at restoring Isagoras

\footnotetext{
${ }^{24}$ Aristotle much later noted that tyrants combined the roles of general and leader of the people, demagogos.
} 
(Sansone, 2009, 133). The advent of the democracy cured many of the ills of Athens and led to a "golden age" for the Athenians.

Athenian society in the sixth century B.C.E. developed increasingly open and democratic institutions, which, by the fifth century, led to the most radically democratic government the world has seen. During the period between 463 (and particularly after 447) and his death in 429, the most influential figure in Athens was Pericles, who lent his name to the whole era, which was regarded as the high-water mark of Athenian power and influence. Though born into the aristocracy and nicknamed the Olympian because of the aloofness of his bearing and manner (Sowerby, 2009, 4), he encouraged and initiated democratic reforms. A successful general, politician and orator, Pericles was a cultivated man who numbered among his friends the philosopher Anaxagoras, the playwright Sophocles and the sculptor Pheidias. Pericles' power to control the assembly stemmed from his talent in oratory and a number of formulations in Pericles' speech showed pride in the freedom of everyday life in Athens and the opportunity that the democracy afforded for individual enhancement and aspirations, and pride as well in the equal protection of the law extended to all citizens regardless of wealth and social standing (Kateb, 2009, 280).

Early in his career, in 462/1, Pericles co-operated with the political leader, Ephialtes, in his attack on the privileges and powers of the ancient Council of the Areopagus. The significance of this move was recorded in The World of Athens $(1984,23)$ that the attack on the powers of this ancient institution was a sign of the trend towards a radical democracy which had no wish to see its decisions influenced or impeded by any unrepresentative and non-responsible body, however venerable. 
A series of democratic reforms was encouraged and initiated. In 487, it was decided that the archons should subsequently be elected by lot one from each of the ten tribes, from 500 candidates nominated by the demes and selected not exclusively from the first class of citizens but from the second class too. Thus the power of the old aristocratic families was severely curtailed. In 454 the archonship was opened up to the third class of citizens (Sowerby, $2009,52)$. First, a sovereign body called the assembly (the ekklesia) took shape, of which all adult male citizens were members. Business was put before it, in the form of motions, by the council of 500 (the boule), to which appointment was by lot from those over thirty. No one could serve on the council more than twice in a lifetime. The Athenian year was split into ten parts of thirty-six days each called a prytany. The council was also subdivided into ten groups of fifty which each presided for a prytany. This was a small enough group to pay, and its members met every day. There were four assemblies per prytany. One was required to take a vote of confidence on the officials then serving, to oversee arrangements for the corn supply and for the defense of the state. At another meeting, petitioners could address the people formally on any subject. The remaining meetings were for other business. The meeting place for the assembly was on the lower slopes of a small hill called the Pnyx near the Agora and the Acropolis, and may have accommodated as many as 6,000 , though we may suppose that numbers were generally much lower. Meetings were begun with the question 'who wishes to speak to the assembly?' In theory any citizen might take up the challenge. Voting seems to have been chiefly by a show of hands. The assembly's decisions were implemented by the council, which also had an important role in financial 
matters. Only those officers whose duties required special expertise, such as the ten generals or certain financial administrators, were not appointed by lot but by annual election with prior nomination. The generals could be re-elected annually. But all officials had to undergo scrutiny before taking office and were accountable upon leaving it. This further weakened the power of the wealthiest and broadened the democratic base of the state. The cornerstones of the developed democracy were therefore sortition (also a feature of the law courts with their mass juries) and rotation, which prevented power being concentrated in factions or individual office-holders (Sowerby, 2009, 54).

Areopagus, a body composed of ex-archons who held office for life (a majority of whom were likely to be aristocratic or wealthy), which had general guardianship of the constitution. Jurisdiction over all cases except those involving homicide was transferred to the popular courts, the Heliaea, so that the people virtually monopolized the administration of justice. Other powers were transferred to the council making the role of the Areopagus largely ceremonial. Pericles then introduced a nominal payment for those who sat on the juries. Thereafter payment for office, for jury-service and even for attendance at the ekklesia might encourage the less wealthy became one of the most characteristic features of the radical democracy (Sowerby, 2009, 54).

This radical democracy is a concept based on the notional of equality of all its free citizens, which may be perceived to be inconsistent with the aristocratic values exhibited by "the best" members of society. Athenian democracy therefore devised the practice of ostracism to remove from the city on a temporary basis any citizen who appeared to pose the risk of subverting democratic values and usurping power as a tyrant (Sansone, 2009, 123). 
However, this did not mean that the Athenians did not own slaves. Indeed, like the Spartans, free Athenians relied very heavily upon the economic contribution of forced labor, the slaves who enjoyed no political rights.

It is impossible to set a date on the moment when the Delian League was transformed into the empire (arkhe) of Athens. It was a long and gradual process. Perhaps the most significant feature was the creation of a belief in the minds of ordinary citizens of Athens that not only were they entitled to enjoy the prosperity which came with the fruits of empire but also that the success of the self-confident, radical democratic system which emerged at Athens was intimately bound up with the possession of the empire. This belief, justified or unjustified as it might be, dominated Athenian thinking for a long time.

In summary, the rise of Athens as a pre-eminent power led to its conflicts with Sparta and other city states in the ancient Greece during the sixth century B.C.E. The open environment encouraged the development of the earliest forms of democratic government. When the tyranny was ended, the Athenians founded the world's first democracy as a radical solution to prevent the aristocracy regaining power. From 443 Pericles was the dominant leader of the people in Athens. His influence depended ultimately on his ability to carry a majority in the Athenian ekklesia with him. A citizens' assembly, the ekklesia, for the discussion of city policy, had existed since the reforms of Draco in 621 B.C.E. All citizens were permitted to attend after the reforms of Solon in the early sixth century, but the poorest citizens could not address the assembly or run for office. With the establishment of the democracy, the assembly became the de jure mechanism of government; all citizens had equal privileges in the 
assembly. However, non-citizens, such as metics (foreigners living in Athens) or slaves, had no political rights at all.

\section{Religion and Mythology}

For ancient Greeks there were many gods and Greek mythology consisted of stories concerning their gods and heroes, the nature of the world and the origins and significance of their religious practices. The main Greek gods were the twelve Olympians, Zeus, his wife Hera, Poseidon, Ares, Hermes, Hephaestus, Aphrodite, Athena, Apollo, Artemis, Demeter, and Hades. Other important deities included Hebe, Helios, Dionysus, Persephone and Heracles (a demi-god). Zeus' parents were Kronos and Rhea who also were the parents of Poseidon, Hades, Hera, Hestia, and Demeter.

The book of The World of Athens, which comprehensively records the history of the classical Greece, has a good account of the Greek gods who were part and parcel of the universe. A Greek god was frequently endowed with a sphere of interest, and they struggled amongst themselves and with humans to ensure that their interests predominate. The Greek gods were very human in their personalities and characteristics $(1984,89)$.

Still at the preliminary stage of civilization, most Greeks were entirely dependent upon the benevolence of nature and needed the religious power in their life. In such an environment, Greeks were aware of their powerlessness before natural forces that might overturn the stable order of things without warning. As with many other agriculturally based tribal peoples, it was reasonable to assume that the Greeks both came to terms with, and remained in awe of, the world around them by positing divine powers to account for 
things beyond their control. Such supernatural powers could explain, for example, the unpredictability of the weather or of fertility (in both crops and humans). More generally, religious stories might be used to explain any strange or incomprehensible event - a meteorite, for example, or an instance of odd behavior, an unexpected illness, or the arrival of a total stranger. For the ancient Greeks, anything abnormal might be a literal indication of divine intervention, and need acknowledgement and conciliation. Such function could be easily found in the ancient Greek literature. For example, in Book 1 of Homer's lliad a plague strikes the Greek army camped outside Troy. Achilles' human response is to consider how the god responsible (which must be Apollo, who is god of healing and illness) can be appeased, so he appeals for a "seer" or "priest or reader of dreams".

The ancient Greek gods might also contact humans through oracles, and it was to oracular shrines that states as well as individuals tended to turn for advice and help, not just in times of national emergency, but to cope with everyday occurrences too. The most influential oracle was at Delphi, but there were many others throughout the Greek world, using all sorts of different methods of divination - clanging pots, rustling leaves, warbling doves, rushing waters, and reflecting mirrors, etc. It was very important to stress that the function of an oracle was not to foretell the future, but to give advice. It was inevitable that, if the advice was good, the oracle would get the reputation for being able to foretell the future, but that was not its function. It was also normal and logical for the Greeks to turn to the experts for interpretation as the modern people turn to experts in politics, economics and social policy. 


\section{Social Values}

The ideals of the Classical Greece were embodied in the funeral oration over the Athenian dead by Pericles (recorded by Thucydides) in the first year of the war with Sparta in 430, which highly stressed the value of the democratic constitution, equality before the law, the absolute recognition of merit, the commercial and cultural pre-eminence of Athens, the love of beauty and philosophy, and the dedication of the individual to the community:

... Taking everything together then, I declare that our city is an education to Greece, and I declare that in my opinion each single one of our citizens, in all the manifold aspects of life, is able to show himself the rightful lord and owner of his own person, and do this moreover, with exceptional grace and exceptional versatility.(Sowerby, 2009, 54)

Besides, the self-assertive competition, for which the Greek word was agon (cf. 'agony'), with a clear distinction between friends and enemies and the sure knowledge that you would be treated as an enemy by the opposition, is one of the important features of the Greek value-system (cf. The World of Athens, 1984, 132); and it had great influence in the ancient Greek life. The regular assertion that it was a man's duty to help his friends (philoi) and harm his enemies (ekhthroi) would arise from the principle of reciprocal action. In the tragic theatre, poets competed aggressively against each other under the public gaze to secure a prize. A lawcourt trial aimed to ensure that one side won and the other lost, not necessarily to see that justice was done. So in many court cases the issue before the jurors often seemed to be "Who started it?" or "How shall we deal with these litigants?" rather than "Where do right and wrong lie?" (The World of Athens, 1984, 132)

Yet there was a consistent counter-balance to the model of a contest as the best pattern for Greek values; and this opposition can perhaps best be 
summed up in one word - sophron (the noun form is sophrosune). The word bears a wide range of meanings_-'prudent', 'discreet', 'sensible', 'chaste', 'law-abiding', 'modest', 'moderate', and 'disciplined'. At heart it implies restraint and acknowledgement of one's own limitations. Its force was perfectly captured by the two famous mottoes inscribed over the entrance to the temple of Apollo at Delphi: "meden agan"("nothing in excess") and "gnothi seauton"("know yourself"). To do nothing in excess and to know oneself was to know what one could and could not do. It was to be constrained by the fact that one was human and not divine; and it was to realize that as a human being one had certain capacities, but not others. The tension between the above patterns of behaviour was a constantly recurring theme of Greek literature.

\section{Intellectual Background}

\section{Early Philosophers}

Between the sixth and fourth centuries B.C, the ancient Greece became one of the cultural centers of the world and the home of intellectuals and artists in all fields. Familiarity with the science and thought of the Babylonians, Persians, and other flourishing civilizations contributed to the intellectual ferment that produced the earliest philosophers in the sixth century B.C.E. in the eastern Greek city of Miletus. Greeks invented philosophy, but the first Greek philosophers were more what we should call "natural scientists". These philosophers were concerned to answer fundamental questions about the origin and the organization of the universe for the first time without recourse to mythical or supernatural entities (Sansone, 2009, 105). They asked the extraordinary question like "Where did the world come from?" and "what is it 
made of?" It is extraordinary because it implies that the universe must be humanly comprehensible, i.e. rational, and therefore explicable in rational terms. While they may have been prompted to undertake their enquiries because of contact with the advanced civilizations of their non-Greek neighbors, it was the open environment of the Ionian Greek poleis, as Sansone observed in his Ancient Greek Civilization, which allowed them to challenge the assumptions of their predecessors and of each other $(2009,105)$.

Little of the Presocratic writing survives except for quotations in later authors, but by common consent the earliest lonian thinker was Thales of Miletus who was born in the latter half of the seventh century B.C.E. He believed that the primary substance from which everything came into being and of which all is ultimately made is water. He explained earthquakes by saying that since the world rested on water, earthquakes occurred when the water was disturbed by the wind. His argument did not sound so scientific by the modern philosophers and scientists, but the important observation to make is that he did not say they were caused by the god of earthquakes, Poseidon.

Parmenides (c. 480 B.C) of the Eleatic school ${ }^{25}$ nearly destroyed the speculation of Thales by denying that change was possible - since how could 'water' change to 'not-water'? It either was or was not water, but it could not be both. Parmenides devastatingly replied that this simply proved that the senses were unreliable guides to the real nature of the world and should not be trusted. Instead, Parmenides believed that Being, the One, is real while Becoming, change, is illusion (Sowerby, 2009, 142). He distinguished two ways of

\footnotetext{
${ }^{25}$ Elea was a Greek colony in southern Italy.
} 
apprehending the world. There is the way of truth in which there is knowledge of Being, which, for Parmenides, is material and the way of opinion that takes the world of Becoming as real. The mutable world of appearances that we apprehend through the senses is unreal; Being is the only true object of knowledge and is known through reason and thought (Sowerby, 2009, 142). This appalling revelation had radical repercussions for Greek thought. To meet Parmenides' objections, one school of thought tentatively proposed an 'atomic' theory of the universe, i.e. that matter consisted of minute indivisible particles below the level of perception, which did not of themselves change, but merely regrouped themselves to make the different shapes, sizes, textures, and tastes of the world we experience.

Also in the late sixth and early fifth centuries, Heraclitus of Ephesus expressed the belief that fire is the primordial substance. The world is an everlasting fire which is partly flaring up and partly dying down in equal measure so that a continuous balance is maintained. Essential to this balance are tension and strife in which all subsists. Unlike other lonian materialists, he associated this primordial element with the logos. This universal reason, the principle whereby there is unity in diversity and diversity in unity, is divine and all-wise and is to be identified with what is eternal and constant, the One, while the phenomenal world is constantly changing and in a state of flux (Sowerby, 2009, 142).

There were other styles of argument and intellectual concerns on the organization of the universe as well. In the second half of the sixth century, Pythagoras of Samos (c. 525 B.C.E.), who, to escape the tyranny of Polykrates, tyrant of Samos, fled to Kroton in South Italy and there set up a 
school which taught a whole way of life, made an important series of observations about the relationship between the natural world and numbers. Associated with Pythagoras is the doctrine of the soul's immortality and its reincarnation in a cycle of lives in the animal and human spheres (metempsychosis). The body is regarded as he prison or tomb of the soul, which may be purified in an ascetic life of study (Sowerby, 2009, 142). He explained the universe not in physical but in metaphysical terms, tracing the origin of all things to numbers. He is accredited with developments in mathematics and music, in particular with the doctrine of the harmony of the spheres, which in their motion were supposed to make heavenly music. The most famous of these is the way in which musical intervals can be expressed in terms of numerical ratios. This led Pythagoreans to suggest that 'number' might lie at the heart of reality, and so began the movement which was to give understanding of nature a mathematical foundation. According to The World of Athens, to the Greek mind the lure of mathematics was its precision, and Plato for one saw in mathematics a perfection which did not exist elsewhere in this imperfect world: "it worked through expressible but unchanging and apparently eternal laws. The Greeks desired to categorize the problems of existence with the precision of mathematics" $(1984,289)$. And with Pythagoras the word 'cosmos', which means "good order" or 'decency' in early Greek, is first used to describe the perfect order and arrangement of the universe.

To sum up, these and other early philosophers were collectively known as the Presocratics. The first philosopher, Thales of Miletos, pronounced that the guiding principle (arkhe) behind everything was water; while other lonian philosophers came to different conclusions about the primordial substance. 
Debates were fiercely joined on a number of topics amongst early thinkers. For them, there was no dogma; and everything was open to question. There was no authority, religious or political, telling them what to think. In many ways, their inquiries had an important influence on modern philosophy, as well as modern science.

In Periclean Athens in the fifth century B.C.E., Socrates began his philosophic mission, and the Socratic philosophy took a new direction. The Roman writer Cicero (106 43) made the famous remark that Socrates first brought philosophy down from the skies to the common problems of mankind (Tusculan Disputations, $\mathrm{V}, 4,10$ ). This may be taken to mean that philosophy moved from physics to ethics. Under his influence, the Greeks turned to the discussions of the nature of justice and the relationship with the written law; the nature of right and wrong, and where expediency fitted in; the nature of power and the rights that the stronger held over the weaker; and, most famous of all, the relationship between nomos and phusis - or, to put it simply, the question "Is there an absolute right and wrong in any situation, or does it depend on the circumstances?" This change, though associated with Socrates, might be seen as a consequence of a greater shift gradually taking place in Greek culture as a whole (Sowerby, 2009, 142).

\section{The Real Teachers-the Sophists}

During this time, there was an unfulfilled need for education and it was a juicy prospect for private teachers to provide higher education in the cultural centre of the Mediterranean, so a number of them flocked to Athens in the fifth century. With the development of radical democracy, there was the need for 
the wealthy young future leaders of the day to develop appropriate skills of persuasion; as a result, many of these teachers were known primarily as in rhetoric. In fact, the sophists taught a vast variety of subjects-from astronomy and law through to Mathematics and rhetoric. It was in large measure due to the sophists that subjects such as grammar, logic, ethics, politics, physics and metaphysics first emerged as separate entities.

These teachers are generally lumped together under the title of 'sophists'. Though Plato (who hated them) has given the word a bad name, many of them were men of the highest intellectual distinction. But their main preoccupation was to describe how man could be most successful in life rather than with scrupulously argued questions of right and wrong of the sort that Socrates and Plato posed. The sophists developed and taught their own specialties. Their significance lies in that the sophists were also in a movement to make man, not the physical world, the centre of intellectual debate. Although it is arguable that the sophists' achievement was as important as Socrates', it was they no less than Socrates who laid the groundwork for Plato's, and later Aristotle's work.

\section{Literature and Theatre}

Ancient Greek society placed considerable emphasis upon literature. Many authors consider that the Western literary tradition began with the epic poems The lliad and The Odyssey, the epics of Homer (c.850 B.C.E.), which remain giants in the literary canon for their skillful and vivid depictions of war and peace, honor and disgrace, love and hatred. In Plato's Apology of Socrates, Socrates quoted in his speech the plot of Homer's Iliad, the epic 
poem about the Greek war against Troy, whose story were familiar to every Athenian.

Athens inspired and attracted poets and artists from the sixth century B.C.E. on a scale unexampled in the rest of Greece. A playwright named Aeschylus changed Western literature forever when he introduced the ideas of dialogue and interacting characters to playwriting. In doing so, he essentially invented 'drama': his Oresteia trilogy of plays has been seen as his crowning achievement. The dramatic works of Aeschylus, the earliest representative of the new genre of tragedy, arose in Athens at the end of the sixth century and flourished in the fifth centuries B.C.E.

Other refiners of playwriting were Sophocles, Euripides and Aristophanes. The tragic poet, Sophocles (c. 496-406 B.C.E.), an Athenian citizen, played his full role in the public life of his city as general and financial expert in addition to his achievements as a poet. Sophocles was credited with skillfully developing irony as a literary technique, most famously in his play Oedipus the King. His younger Athenian contemporary, the tragic dramatist Euripides (485-406 B.C.E.) used plays to challenge societal norms and mores—a hallmark of much of Western literature for the next 2,300 years and beyond-and his works such as Medea, The Bacchae and The Trojan Women are still notable for their ability to challenge our perceptions of propriety, gender, and war. The plays of Euripides were quite popular with Athenian audiences but, at the same time, they created considerable controversy. Euripidean characters are exceptionally articulate in their challenging of received notions and in their insistent demands that society and even the gods adhere to a rational pattern of behavior (Sansone, 2009, 189). Aristophanes, a 
comic playwright, defined and shaped the idea of comedy almost as Aeschylus had shaped tragedy as an art form—Aristophanes' most famous plays included the Lysistrata and The Frogs. The popularity and the controversial nature of Euripides' tragedies made him a natural target for parody in the comedies of his contemporary Aristophanes..

These Athenian dramatists left great influence on Socrates. In his speech, Socrates used to quote part of a verse from the lost tragedy of Euripides Melanippe the Wise, "not mine is the tale , but from my mother". However, he replaced Euripides' words for tale, mythos, with logos. The verse occurred in a rationalistic account of the generation of the world that omitted any mention of gods (West and West, 1998, 68-9). In Aristophanes' comedy The Clouds, Socrates was portrayed as a godless charlatan who used his devious intelligence to swindle unsuspecting citizens. Aristophanes, examined by Sansone $(2009,189)$, might not have believed that Socrates was in fact an atheist, but his portrayal of the philosopher as denying the existence of the traditional gods contributed to "a prejudice among his fellow citizens that undoubtedly influenced the outcome of a trial that Socrates was subjected to" $(2009,189)$.

\section{Science and Technology}

During the Classical Greece, science and technology also enjoyed substantial development. In mathematics, the discoveries of several Greek mathematicians, Pythagoras, Euclid, and Archimedes, including the basic rules of geometry, the idea of formal mathematical proof, and discoveries in number theory, mathematical analysis, applied mathematics, and approached 
close to establishing integral calculus, are still used in mathematical teaching today. They were the great contributions of the ancient Greek mathematics for the field of mathematics.

In the fourth and fifth centuries B.C.E., the Greeks developed astronomy to a highly sophisticated level. For them, astronomy was a branch of mathematics. The first geometrical, three-dimensional models to explain the apparent motion of the planets were developed in the fourth century B.C.E. by Eudoxus of Cnidus and Callippus of Cyzicus. Their younger contemporary Heraclides Ponticus proposed that the Earth rotates around its axis.

The ancient Greeks also made important discoveries in the medical field. Hippocrates was a physician of the Classical period, and was considered one of the most outstanding figures in the history of medicine. He has been referred to as the "father of medicine" in recognition of his lasting contributions to the field as the founder of the Hippocratic school of medicine. This intellectual school revolutionized medicine in the ancient Greece, establishing it as a discipline distinct from other fields. Furthermore, giving a rational account of an illness and assessing the value of evidence adduced formed an important part of medical casework, and this principle was extended to other spheres of human life (e.g. political and moral) in the Classical Greece.

Much work was going on in other fields at this time too, and the evidence could be easily found in Aristophanes' Clouds. In this play, when the rustic Strepsiades is introduced into Socrates' private school (phrontisterion or 'think tank'), he finds all sorts of extraordinary devices cluttering up the place:

Strepsiades: [examining some of the objects in the phrontisterion] Tell me, what on earth are these?

Student: This is astronomy.

Streps.: And this?

Student: Geometry. 
Streps.: $\quad$ And what is the use of it?

Student: It is for land measurement.

Streps.: For a new settlement?

Student: For any land whatever.

Streps.: That's a smart dodge. What a useful democratic device.

Student: And here we have a map of the world. This is Athens ...

Streps.: Come off it. I don't believe you. Where are the juries?

(Aristophanes, The Clouds, 200ff.)

These cosmic models, which might be celestial globes, star maps, compasses, and maps, are an important feature of the play, where the association between the new thought and its various trappings is constantly being made. It suggests that the use of models and apparatus was understood well enough by the fifth-century Athenians.

\section{Art and Architecture}

It might be Pericles who was probably the inspiration of the lavish building programme which from 450 B.C.E. onwards. Grandiose building projects, the beautiful black-figure pottery from Athenian workshops, the poets, attracted by patronage and the remodelled Great Panathenaic festival, all testified to the increasing self-confidence of the Athenians of this period. The Parthenon and other shrines and buildings were on the Acropolis, and theatres and gymnasia were put up elsewhere in the city. Artists and architects, such as Pheidias, Iktinos and Mnesikles, worked on the schemes. Athens' most famous building, the Parthenon, a temple dedicated to Athena Parthenos (meaning 'maiden'), was located on the Acropolis in Athens, which began in 447 and completed in 438/7. It was regarded as one of the most representative symbols of the culture and sophistication of the ancient Greeks. These buildings represented the culmination of Athens' revival after its destruction in the Persian Wars. The art and architecture of ancient Greece has exercised an 
enormous influence on the culture of many countries from ancient times until the present.

To sum up, between the earliest speculations of the Presocratics and the time when Socrates had come of age in about 450 B.C.E. came the full flowering of Attic tragedy, in which practical human problems and questions of a philosophic, religious and ethical nature were raised and debated in dramatic form. Developments in philosophy may be seen as a natural accompaniment or consequence of other imaginative and empirical explorations in literature, science and technology, arts and architecture. Together they all served the complementary aspects of the growing Greek enlightenment.

\section{Summary}

The Ancient Greece was a period that lasted from the Archaic period to the end of antiquity. Its fragmentary nature in geography, with many competing city-states, led to regionalism and the increased frequency of regional conflicts. Athenian society in the sixth century B.C.E. developed increasingly open and democratic institutions resulting, by the fifth century, in the most radically democratic government the world has seen. At the preliminary stage of civilization, most Greeks were dependent upon the benevolence of nature and needed the religious power in their life; and the most influential oracle at that time was at Delphi. Certain values such as achievement, competition and self knowledge were emphasized in the society. Around the sixth and fourth centuries B.C.E., the ancient Greece became one of the cultural centers of the world, and the Greeks had an eager individualistic strain that led them to high levels of creative thinking in a number of fields such as literature, science, and 
architecture. In politics, philosophy, ethics, and rhetoric, and then in the more scientific disciplines (mathematics, astronomy, and medicine), thinkers of the stature constructed systematic disciplines which were to be held valid for thousands of years; and in literature, theater and architecture, the poets, dramatists, and architects created works of such excellence that they were to be of lasting significance. Whatever the reasons for this sudden burst of powerful intellectual activity, one cannot separate the achievements of the Athenians, at least, from their open environment in which people as a whole felt a strong sense of their own independence of judgment and the sense of freedom as people felt the right to control their own destinies. Most of all, the early intellectuals conducted their speculations in a free atmosphere, in which issues were not settled by certain authorities, but by the capacity to convince free, thinking men of the correctness of their views.

At the same time, the Greeks' fascination with rational inquiry began with the pre-Socratic philosophers (Thales, Heraclitus, and Pythagoras, etc.), who preferred reason and logic above observation and experience. In general there was an increasing interest among Greeks in what sort of evidence was acceptable to prove or disprove a case. Giving a rational account of an illness and assessing the value of evidence adduced formed an important part, for example, of medical casework, and this principle was easily extended to other spheres of human life (political and moral, for example). This point has been proved by Thucydides, the Greek historian, who discussed how he gathered the evidence for his history:

"My own narrative is based on the clearest evidence that can be expected considering the antiquity of the events ... not on a casual enquiry nor on my personal opinion, but partly on my own experience and partly by following up as closely as I could the accounts of eyewitnesses. This last process was a difficult 
one because the accounts of eyewitnesses differed according to memory and partiality." (Thucydides, Peloponnesian War 1.22)

Greek culture had a powerful influence on the Roman Empire, which

carried a version of it to many parts of the Mediterranean region and Europe. It has been immensely influential on politics, philosophy, science, literature and the arts. The civilization of ancient Greece has also been regarded as the seminal culture which provided the foundation of Western civilization in general.

\section{B. Chinese Society before the 4th Century B.C.E.}

\section{Historical and Social Background}

China is a vast country located on the continent of Asia. Unlike the fragmentary ancient Greece, the Chinese kingdoms ruled over large territories. China has a great variety of climates and terrains. In the west of China there are the Himalayas, with some of the highest mountains in the world. In the history, as the Chinese territory was separated from others by deserts and by sheer distance, the Chinese civilization also developed independently from the very early time. After 10,000 B.C.E. people in China lived by hunting and gathering plants. Then, about 5,000 B.C.E., the Chinese began farming. As one of the oldest continuous civilizations of the world, its people wrote about the history of China 3500 years ago.

\section{Political Government and Social Classes}

The ancient China was said to begin as city-states in the Yellow River valley. Wars and civil wars were fought and they also sometimes conquered by 
other people. Between about 2,000 and 1,750 B.C.E. the semi-legendary Xia ${ }^{26}$ (circa 2205 B.C.E.-circa 1766 B.C.E.) ruled parts of China. Turtle shells with the ancient Chinese writings appeared about 1500 B.C.E. in the Shang ${ }^{27}$ Dynasty. The ancient Chinese used characters and symbols as their written language. The Shang nobles were very fond of hunting and no doubt had enjoyable lives. During the Shang era slavery was common in China.

Prisoners of war were made into slaves. Human sacrifice was still practiced. When a Shang emperor died his servants and slaves either committed suicide or were killed to accompany him into the afterlife.

The political system before the Zhou ${ }^{28}$ dynasty (1022-221 B.C.E.) could be regarded in general as patriarchal. The king was the sire, and his officers were responsible elders of different departments and districts, such as every father of a household was to its inmates. The king derived his power chiefly from his forefathers, and people obeyed him because he was the descendant of those persons whom their forefathers had obeyed. So his chief duties were to offer sacrifices to his ancestors, and to protect his people, the descendants of the people of his ancestors, from their enemies or other calamities. In fact, the ancient Chinese people were, as Chen described, "ruled largely by the spirits of their ancestors - the early fathers of their families" $(1990,47)$.

Zhou overthrew the Shang about 1022 B.C.E. So began the Zhou dynasty which ruled China from about 1022 B.C.E. to 221 B.C.E. The part of the Zhou era from 1022 B.C.E. to 771 B.C.E. was called the Western Zhou, 
because the rulers had their capital in the west of China. In 771 the Rong ${ }^{29}$, a people from the west, invaded and the Zhou was forced to move their capital to the city of Luoyang ${ }^{30}$ in the east of China. Afterwards the power of the Zhou kings declined. In those days because transport and communications were very slow it was difficult for a ruler to control a wide area. The Zhou kings solved this problem by creating a feudal state. The Zhou state broke up into separate states, although there was still nominally a single state with a Zhou king at its head. The nobles under the Zhou king effectively became independent rulers. For years, the different states went to war and the stronger ones swallowed the weaker till there were only a few left. Finally around 221 B.C.E., one state, the $\mathrm{Qin}^{31}$, conquered its rivals and its ruler became emperor of China. And thus began the Qin dynasty. In the Chinese history, the part of the era from 770 to 476 B.C.E. was called the Spring and Autumn period ${ }^{32}$; and the part from 475 to 221 B.C.E. was called the Warring States period ${ }^{33}$. Like Socrates, the age in which Confucius (551-479 B.C.E.) lived was characterized by great socio-political unrest. By this period, the mighty Zhou dynasty had degenerated into a system of loosely-bound feudal states that were engaged in continuous and interminable warfare, much to the distress of the common people. Thus, in the turmoil and suffering the grassroots people submitted themselves to the whims and caprices of the aristocracy.

Although warfare was frequent during the Zhou era trade and commerce flourished and Chinese cities grew larger. Furthermore agriculture was greatly

\footnotetext{
29 戎

30 洛阳

31 秦

32 春秋时代

33 战国时代
} 
improved by iron tools and by irrigation, which became more common. As a result of more efficient agriculture, the population of China grew rapidly in the Zhou period. Cities, as centres for circulating merchandise, developed rapidly. Wealth of the states, as a whole, was also increased. Communication between different states was greatly facilitated, chiefly for military purposes. All these-the increase of production, cities, wealth, and travelling facilities-gave rise to the number and importance of the middle class people in society.

Under the feudal system of the early Zhou Empire, the upper class of the society was the overlords, including the emperors (Sons of Heaven ${ }^{34}$ ), feudal lords, ministers and great officers. Chinese rulers, called emperors, claimed to embody a heavenly mandate to judicial and executive authority ${ }^{35}$. Apparently, they were on a social and legal tier above the gentry and the officials. In the later part of the Zhou dynasty, a number of feudal states came into being, and land was given to the followers of emperor, the feudal lords, who in return provided chariots and soldiers to the emperor in time of war. Soon the positions of these groups of people became hereditary. Below them were officials who worked as generals and administrators. From existing literary evidence, commoner rankings in China were employed for the first time during the Warring States Period (c.f. Barbieri-Low, 2007, 37). Despite this, Eastern-Han historian Ban Gu ${ }^{36}$ (32-92 B.C.E.) asserted in his Book of $\mathrm{Han}^{37}$ that the four occupations for commoners had existed in the Western Zhou (c. 1022 B.C.E. - 771 B.C.E.) era, which he considered a golden age. Ban

\footnotetext{
34 天子

${ }^{35}$ Such mythmaking was, observed by Richey, very important to the emerging imperial Chinese state, as it struggled to impose cultural unity on a vast and fractious territory during the final few centuries B.C.E. and beyond into the Common Era. (c.f. http://www.iep.utm.edu/confuciu/)

36 班固

37 《汉书》
} 
explained the social hierarchy of each group in descending order: shi ${ }^{38}$ (gentry scholars), the nong ${ }^{39}$ (peasant farmers), the gong ${ }^{40}$ (artisans and craftsmen), and the shang ${ }^{41}$ (merchants and traders). It was a hierarchic social class structure developed in ancient China as far back as the late Zhou Dynasty and was considered a central part of the feudal social structure.

\section{The shi (士)}

During the ancient Shang and Zhou dynasties, the shi were regarded as a knightly social order of low-level aristocratic lineage compared to dukes and marquises. This social class was distinguished by their right to ride in chariots and command battles from mobile chariots, while they also served civil functions. They were also distinguished by the weaponry they used, the double-edged sword, or jian ${ }^{42}$. The type of clothing worn by the shi class also distinguished them from others: the shi wore long flowing silken robes, while all other men wore trousers (Gernet, 1962, 129-130). As chariot warfare became eclipsed by mounted cavalry and infantry units with effective crossbowmen in the Warring States Period, the participation of the shi in battle dwindled as rulers sought men with actual military training, not just aristocratic background. This was also a period where philosophical schools flourished in China, while intellectual pursuits became highly valued amongst statesmen. Thus, the shi eventually became renowned not for their warrior's skills, but for their scholarship, abilities in administration, and sound ethics and morality 
supported by competing philosophical schools. Thus the identity of the shi class changed over time, from an ancient warrior caste, to an aristocratic scholarly elite, and finally to a bureaucratic scholarly elite with less emphasis on archaic noble lineage.

During the Zhou period many people in the shi class studied in order to occupy positions of rank and hence they could advise kings and rulers on the right way to behave and also how to carry out rituals. Among them, the most important one was Confucius, who appalled by the chaotic social and political affairs, tried to restore ancient principles. Later on the shi class developed into one of the most influential class of people in Chinese society.

\section{The nong (农)}

Those who cultivated the soil and propagated grains were called nong (farmers). Since Neolithic times, agriculture has been a key element to the rise of China's civilization. The food that farmers produced sustained the whole of society, while the land tax exacted on farmers' lots and landholders' property produced much of the state revenue for China's pre-modern ruling dynasties. Therefore, the farmer was a valuable member of society. Usually, the poor farmers who being landless, were mere agricultural serfs of their political and economic overlords, serving them in the fields in tune of peace, and in the army, if necessary, in time of war.

\section{The gong (工)}

Artisans and craftsmen belonged to the class gong, which identified with the Chinese character meaning labor. They were much like farmers in the 
respect that they produced essential goods needed by themselves and the rest of society. Although they could not provide the state with much of its revenues since they often had no land of their own to be taxed, artisans and craftsmen were still given a higher place than merchants. Since ancient times, the skilled work of artisans and craftsmen was handed down orally from father to son, although the work of architects and structural builders were sometimes codified, illustrated, and categorized in Chinese written works. Artisans and craftsmen were either government-employed or worked privately. A successful and highly skilled artisan could often gain enough capital in order to hire others as apprentices or additional laborers that could be overseen by the chief artisan as a manager. Hence, artisans could create their own small enterprises in selling their work and that of others, and like the merchants, they formed their own guilds.

\section{The shang (商)}

Those who transported valuable articles and sold commodities were called shang (merchants). Traditionally, the merchants, traders, and peddlers of goods were viewed by the scholarly elite as essential members of society, yet were placed on the lowest of the four grades in the official Chinese social hierarchy due to the view that they do not produce anything, only profit from others' creations.

Anthony J. Barbieri-Low, Professor of Early Chinese History at the University of California, Santa Barbara, writes that the classification of "four occupations" can be viewed as a mere rhetorical device that had no effect on 
government policy $(2007,37)$. However, certain social and cultural values could be traced from the classification. There were motives behind the aristocratic officials and later scholar-officials' classifying of certain groups in the hierarchy and leaving others out. The scholar-officials placed farmers as the second most prestigious group because the aristocratic officials and scholar-officials were landholders themselves, much like farmers (the ones who weren't tenant farmers or serfs). Both farmers and artisans were placed on a higher tier than merchants because the two former groups produced crops and manufactured goods, essential things needed by the whole of society.

There were many social groups that were precariously excluded from the four broad categories in the social hierarchy. These included soldiers and guards, religious clergy and diviners, eunuchs and concubines, entertainers and courtiers, domestic servants and slaves, prostitutes, and low class laborers other than farmers and artisans.

\section{Religions}

The issue of the religion in China was much for debate. Some scholars doubt the use of the term "religion" and suggest "cultural practices", "thought systems" or "philosophies" as more appropriate names (He \& Peng, 2009, 13; Li, 1986, 25; and Yao, 2000, 7, etc.). And it has been characterized by pluralism since the beginning of Chinese history.

In ancient Chinese cosmology, the universe was created not by divinities but self-generated from the interplay of nature's basic duality: the active, light, 
dry, warm, positive, masculine yang $^{43}$ and the passive, dark, cold, moist, negative $\operatorname{yin}^{44}$. All things, animate and inanimate, and all circumstances were a combination of these fundamentals. The ultimate principle of the universe was the dao ${ }^{45}$, "the way", and it determined the proper proportions of yin and yang in everything. Anything that altered the natural relation of yin to yang was considered bad, and right living consisted of carefully following the dao. If one observed the dao by moderation, equanimity, and morality, one would be impervious to disease and resistant to the ravages of aging; disregard of the dao led to illness, which was not so much a punishment for sin as the inevitable result of acting contrary to natural laws. However, illness also could be caused by forces beyond one's control, and atmospheric conditions could upset the harmonious inner balance of the yang and yin. One had to be alert to this possibility and combat its effects as well as modify internal imbalances of the vital forces. Longevity and health were the rewards (He \& Peng, 2009, 179). Furthermore, $\mathrm{Fu} \mathrm{Xi}^{46}$ (c. 2900 B.C.E.), the most ancient legendary emperor in China, was said to have originated the $\mathrm{Ba}$ gua ${ }^{47}$, a symbol composed of yang lines and yin lines combined in eight $\left(\mathrm{ba}^{48}\right)$ separate trigrams $\left(\mathrm{gua}^{49}\right)$ which could represent all yin-yang conditions. This system was recorded and elaborated in the I Ching ${ }^{50}$ (Book of Changes). Influenced by this book and the ancient Chinese philosopher Laozi ${ }^{51}$ and his work Taode Jing ${ }^{52}$ in the sixth

\footnotetext{
43 阳

44 阴

45 道

46 伏羲

47 八卦

48 八

49 卦

50 《易经》

51 老子, also written as Lao-tzu,
} 
century B.C.E., an early indigenous form of religious practice in Chinese history later began to develop from the more primitive elements of animism and folk religions, known as Taoism $\left(\right.$ Daojiao $\left.^{53}\right)$, which has been considered a traditional Chinese religion.

Tribal or primal religious practices were common during the Xia and Shang dynasties, in which prayers, sacrifices or offerings were communicated to the spiritual world by groups or mediatory individuals. Major local deities were figures from Chinese mythology include Mazu ${ }^{54}$ (goddess of the seas, patron of Southern China), Huangdi ${ }^{55}$ (divine patriarch of all the Chinese, "Volksgeist" of the Chinese nation), and the Dragon ${ }^{56}$. During the Shang dynasty the practice of ancestor worship began (Yao, 2000, 35). Ancestor worship was the belief that the dead could intervene in the affairs of the living. Offerings were made to them to keep them happy. This practice became part of Chinese culture for thousands of years.

Human sacrifice ended during the Zhou era but divination continued. At that time the Chinese concept of heaven $\left(\operatorname{tian}^{57}\right)$ emerged. Heaven was a kind of universal force. Heaven chose the emperor to rule but it was a moral force. It was believed that if the king or emperor were evil heaven would send natural disasters as a warning. If the emperor failed to heed the warnings heaven would withdraw its mandate. Social and political order would break down and depicted as long, scaled and snake like creatures with five claws. These dragons have been symbol of auspicious power in the Chinese folklore and art. 
there would be a revolution. Heaven would choose somebody else to rule (Yao, $2000,60)$.

\section{Social Values}

China has vast territory and large population. Throughout the ages, people have become accustomed to live together intensively, which makes the social concept go into people's minds deeply. The links, influences and roles between people exist in people's consciousness. It has also produced a social custom, and living in such an environment for a long term has made Chinese people have the strongest social attitudes. There are lots of opportunities people can contact with each other, and they do not begrudge the care and help with each other. Even if it is one person's thing, the whole family would help. "All men are brothers", "When disaster struck, help came from all sides", these two proverbs are the full embodiments of the concept of group.

In this agricultural culture, collectivism and conformity have been the core values, primarily because it was more functional to conform to authorities while public works (e.g, building of irrigation canals) were being performed. Thus, the Chinese traditionally viewed society as being the source for the circumscribing characteristics of the individual. In this collective society, personal desires should be subordinated to the needs of the in-group, and the self exists in relation to others. In the interdependent Chinese society it is held that only within their relationships to others do individuals have weight. This collective trait could be found in ancient Chinese literature Shi Jing (the Book of Poetry), the first surviving collection of Chinese poems; and the Pre-Qin prose Spring and Autumn Annals. Also in philosophy, the collective values 
could be captured in the work of many other ancient Chinese philosophers such as Laozi and Mengzi.

\section{Intellectual Background}

Similar to the age of Socrates, there was one of the greatest intellectual upheavals in ancient China, beginning from the Spring and Autumn period (c. 770 B.C.E.) down to the end of the period of the Warring States (221 B.C.E.). The general political, social and moral chaos, that allowed the greatest freedom of thought, created the situation of a great demand for scholars, and set every keen mind thinking about the best way of bringing about peace and order, which all had a great deal to do with the intellectual upheaval.

Another cause for all the vigorous thinking of this age could be attributed to the rich cultural heritage that had come down from the remote past of Chinese civilization. Confucius lived in the Zhou period with its culture well preserved, and naturally he took the culture from the previous dynasties as the background of his teaching. Confucius mentioned many times in the Analects the culture of Xia (circa 2205 B.C.E.-circa 1766 B.C.E.), Shang (circa 1766 B.C.E.-circa 1122 B.C.E.), and the early Zhou, which formed the general intellectual background of Confucius' teaching ${ }^{58}$, as well as the teachings of all later philosophers.

\footnotetext{
58 typical example is in "Wei Zheng", Bk. II of Analects. Zi Zhang asked whether the affairs of ten ages after could be known. Confucius said, "The Yin (Shang) dynasty followed the regulations of the Xia; wherein it took from or added to them may be known. The Zhou dynasty has followed the regulations of Yin (Shang); wherein it took from or added to them may be known. Some other may follow the Zhou, but though it should be at the distance of a hundred ages, its affairs may be known." (The Analects, Bk. II, Ch. XXIII.) (子张问：“十世可知也？” 子曰: “殷因于夏礼，所损益，可知 也; 周因于殷礼, 所损益, 可知也; 其或继周者, 虽百世可知也。” (《论语 为政第二-二十三》)
} 
Modern excavations have shown that the Shang and the early Zhou people were very fond of writing. Thousands of pieces of bone and tortoise shell of the late Shang dynasty have been found inscribed with characters, and "every important principle of the formation of modern Chinese characters was already in use, to a greater or less degree" (Chen, 1990, 63). Many bronze vessels of the early Zhou period have also been discovered carrying inscriptions with characters.

Early literature in China began with the book I Ching ${ }^{59}$ (Yi Jing, also known as The Book of Changes). The name of I Ching was probably given by the early Zhou people, and had to do with methods of divination which were very commonly practiced in the early Zhou and the Shang periods. From the very early time, most of the inscriptions of the oracle bones were connected with divination. Later on the methods or techniques of divination of different sorcerers' manuals were collected, selected and commented on until the present form of I Ching or The Book of Changes was obtained. As mentioned, the important idea of Yin and Yang was also recorded in this book, in which it was believed that all matter was made of two opposite and complimentary principles: Yin is feminine, soft, gentle, dark, receptive, yielding and wet; while Yang is masculine, bright, hard, hot, active, dry and aggressive. The ancient Chinese also believed there were five fundamental elements, namely wood, fire, earth, metal and water. All these made up the all the elements in the world which were interconnected and interactive. The I Ching in its original form, that is, without its commentaries, was possibly the first complete work of Chinese literature (Chen, 1990,67) and it doubtless existed completely in its original 
form before the time of Confucius. Confucius probably read or knew much about it, and was impressed especially by its principle of "change", as that "It passes on just like this, not ceasing day or night!"60

During the Shang and Zhou dynasties, poetry also enjoyed substantial development. The Zhou people were fond of singing. They sang when they were in sorrow, about the death of relatives, the trials of military service, the evils of society, or personal hardships; in happy moods, about feasting, dancing, ceremonial offerings, or thanksgiving sacrifices to ancestors or to other spirits. There mere songs of love between man and woman, songs of admonition, praise and prayer, and songs of the chase and the court; and all these were collected and selected in the Book of Poetry (Shi Jing ${ }^{61}$, also known as the Book of Songs). The book was exceedingly popular during the Zhou period, and soon became one of the most important wring records of that time (Chen, 1990, 328). The poems and songs recorded were widely used then on during important occasions such as feasting, sacrificing, etc., and also often used by scholars in daily conversations or in letter and essay writing. In the Analects, Confucius quoted and explained the lines of verse from the Book of Poetry as he believed they were both beneficial and important for one's well being.

There were other forms of literary works. Speeches made at various occasions by kings and other rulers, such as political proclamations, moral and admonitory communications and exhortations, and other miscellaneous

\footnotetext{
60 The Master standing by a stream, said, "It passes on just like this, not ceasing day or night!" (The Analects, Bk. IX, Ch. XVII.) (子在川上, 曰: “逝者如斯夫! 不舍昼夜。”《论语 子罕第九十十七》)

61 《诗经》
} 
documents were later collected and selected in the Shu Jing ${ }^{62}$, generally known as the Book of History. There was also a book about rites. The early Zhou people were very careful in respect to the various ceremonial rites and observances on important occasions, such as marriage, birth, death, burial, offering of sacrifices, ceremonial visits and feasts; and also in everyday life. These were later collected and selected in the book $L i J i^{63}$ or The Book of Rites.

In addition, music was used to a very great extent by the early Zhou people especially in singing, dancing, feasting, and in different kinds of religious practices. There were many kinds of musical instruments mentioned in the literature at that time, and some of these have been discovered by modern archaeologists (Chen, 1990, 66). The early musical instruments could be generally classified into three groups: those to be held in the hand when beaten, such as $\mathrm{Nao}^{64}$ and Zheng ${ }^{65}$; those to be hung up when beaten, such as Zhong ${ }^{66}$ and Bo ${ }^{67}$; those with clappers, such as Ling $^{68}$ and Duo ${ }^{69}$ (c.f. The Illustrated Catalogue of Chinese Government Exhibits for the International Exhibition of Chinese Art in London, 1985, Vol. 1). There were also stone chimes, and wind and string instruments. Confucius was recorded as having been much interested in music. He probably have composed, selected and revised some of the music of his time, and talked much to his disciples about music, and very likely wrote treatises on music (Chen, 1990, 66). Traditionally 
it is believed there was a collection of ancient music, known as Yue $\mathrm{Jing}^{70}$, or the Book of Music. But unfortunately it was lost during or before the Han dynasty, probably after 85 C.E., so that all we have today is a chapter on music in Li Ji (The Book of Rites).

There were also annals of different states. A large part of the original materials of the annals of different states have been preserved in Zuo Zhuan $^{71}$ (also known as Chunqiu Zuo Zhuan ${ }^{72}$ ), which was a vivid chronicle of events in the feudal states of China between 722 and 468 B.C.E. Zuo Zhuan has long been considered both a major historical document and an influential literary model. Covering over 250 years, these historical narratives focused not only on the political, diplomatic, and military affairs of ancient China, but also on its economic and cultural developments during the turbulent era when warring feudal states were gradually working towards unification. As one of the earliest Chinese works of narrative history, it is one of the most important sources for understanding the history of the Spring and Autumn Period. Ending shortly after Confucius' death in 479 B.C.E., Zuo Zhuan provided a background to the life and thought of Confucius and his followers.

All the above writings produced during this period are generally grouped under six headings, known as the $\mathrm{Liu} \mathrm{Yi}^{73}$, or "Six Disciplinary of Arts", namely, Poetry, Documents, Rites, Music, Changes, and Annals, which formed the basic literature at the time of Confucius. Besides this basic literature, there were also writings about the arts of archery, charioting fencing, writing,

\footnotetext{
70 《乐经》

71 Also spelt as Tso Chuan, 《左传》. Sometimes it is translated as the Chronicle of Zuo or the Commentary of Zuo (also Tso). Zuo Zhuan is traditionally attributed to Zuo Qiuming, as a commentary to the Spring and Autumn Annals.

72 《春秋左传》

73 “六艺”
} 
counting, medicine, handicraft, etc., which were important to the early Zhou people.

\section{The Philosopher Laozi and his Taode Jing ${ }^{74}$}

The philosophical school which might have existed before Confucius and greatly influenced his teaching was the philosophy of Laozi, who lived around the sixth century B.C.E. The earliest reliable reference to Laozi is found in the Records of the Grand Historian (Shiji) by Chinese historian Sima Qian (ca. 145-86 B.C.E.). Laozi, by which what we call him, is generally considered an honorific, with the literally meaning of "Old Master". Lao ${ }^{75}$ means "venerable" or "old"; and $\mathrm{Zi}^{76}$, in this context is typically translated "the master". Zi was used in ancient China as an honorific suffix, indicating "Master", or "Sir". In popular biographies, the surname of this ancient Chinese philosopher was $\mathrm{Li}^{77}$, and his given name was $\mathrm{Er}^{78}$ (the ear). $\operatorname{Dan}^{79}$ is a posthumous name given to Laozi, so he was sometimes referred to as Li $\operatorname{Dan}^{80}$. According to popular traditional biographies, Laozi spent most of his life as an archivist in the library of the Zhou Dynasty court. This reportedly allowed him broad access to the classics and the works of his time. He quitted when he saw things were getting corrupt, and then went into exile. Laozi became disturbed by the corruption he saw everywhere around him and decided to leave the country. He traveled west on a water buffalo to reach the great desert. At the westernmost gate, a

\footnotetext{
${ }^{74}$ Also spelt as Tao Te Ching.

75 老

76 子

77 李

78 耳

79 聑

80 李聑
} 
guard who recognized him, demanded that he write down his teachings, unrecorded until this point. The collected teachings became the Daode Jing. Although there have still been lots of disputes about the date of Laozi among Chinese scholars (Chen, 1990, 56 and He \& Peng, 2009, 130, etc.), yet the consensus of opinion seems to indicate that it might be possible that such a man, Laozi, lived contemporaneously with Confucius, with whom Confucius might have had an interview (Chen, 1990, 74; Feng, 1983, 50).

Laozi has been traditionally regarded as the author of the Daode Jing, which was one of the most significant treatises in Chinese cosmogony. Similar to most other ancient Chinese philosophers, Laozi often explained his ideas by way of paradox, analogy, appropriation of ancient sayings, repetition, symmetry, rhyme, and rhythm. In fact, the whole book of Daode Jing can be read as an analogy. In the book, Dao ${ }^{81}$ (or Tao) was described as the source and ideal of all existence: it is unseen, but not transcendent, immensely powerful yet supremely humble, being the root of all things. Another central concept in the book was wu wei ${ }^{82}$. With the literal meaning of "non-action" or "not acting", the concept of wu wei was multifaceted, and had multiple meanings in translation.

\section{Summary}

Like Socrates, the age in which Confucius lived was characterized by great socio-political unrest. By this period, the mighty Zhou dynasty had degenerated into a system of loosely-bound feudal states that were engaged

\footnotetext{
81 道

82 无为
} 
in continuous and interminable warfare. Meanwhile, the increase of production, cities, wealth, and travelling facilities gave rise to the number and importance of the middle class people in society. During the Zhou period many people in the shi class studied in order to occupy positions of rank and hence they could advise kings and rulers on the right way to behave. Among them, the most important one was Confucius, who appalled by the chaotic social and political affairs, tried to restore ancient principles. Collectivism and conformity are prevalent social values.

Besides the political, economical and social background, this section also introduces the ancient Chinese view of the world. For them, the universe was created not by divinities but self-generated from the interplay of nature's basic duality: yang and yin. This system was recorded and elaborated in the I Ching or The Book of Changes, which greatly influenced the ancient Chinese philosopher Laozi and his work Taode Jing in the sixth century B.C.E. In the great intellectual upheaval beginning from the Spring and Autumn period (c. 770 B.C.E.), there were other various writings produced during this period; and they were generally grouped under six headings, known as the Liu Yi, or "Six Disciplinary of Arts", namely, Poetry, Documents, Rites, Music, Changes, and Annals, which formed the basic literature at the time of Confucius. In this agricultural culture, collectivism and conformity have been the core values. By way of paradox, analogy, and appropriation of ancient sayings, the Chinese early philosophical trend resorted more to intuition than reason, as shown in I Ching, or The Book of Changes, Laozi's Taode Jing and other early Chinese literary writings. 


\section{CHAPTER IV. COMPARISON (CULTURAL}

\section{INTERPRETATIONS) OF SOCRATIC AND}

\section{CONFUCIAN PHILOSOPHY OF EDUCATION}

The discussion of Socratic and Confucian education philosophy is the core section of the thesis, and it is in close connection with the previous chapter which deals with the different social and cultural trends in the two civilizations. The comparison will cover the following basic issues of Philosophy of Education:
A. The aim of education (why);
B. The content of education (what);
C. The teaching/education process (how); and
D. The nature of education

\section{A. The Aim of Education}

\section{SIMILARITIES:}

1. Both Socrates and Confucius shared the aim of self-cultivation I self-improvement.

For Socrates, the truth became clear to his interlocutor in the cross examination, and clearer to Socrates himself. Individual Moral Good is one 
major aim of education in Socratic thought. According to him, the acquisition of knowledge is valuable for man because it makes him virtuous and happy. Socrates rejected any ornamental theory of knowledge and disapproved the use of knowledge merely for material success in life. For him, knowledge is ethically and morally important for all men.

For Confucius, "The superior man learns in order to reach to the utmost of his principles." (The Analects, Bk. XIX, Ch. VII.) (君子学以致其道《论语 子 张第十九-七》) The idea contained is central to Confucian teaching, which means that the pursuit of learning is regarded as the only path toward the highest goal of Confucianism: self-perfection. One of the central ideas in Confucian Analects is also to search for a higher meaning of life.

\section{Both of them aimed to benefit those who conversed with them or heard them.}

Apart from self-improvement and self-perfection, both philosophers also aimed to benefit those they had conversations with. In his apology to the jury (Xenophon 15-6), Socrates confessed that "I know that, for me too, it will be borne out both by the time to come and by the time past that I never did injustice to anyone or made anyone more base but benefited those who conversed with me by teaching without charge whatever good thing I could." According to Xenophon (177), Socrates "profited those who spent time with him no less when he was playful than when serious". (Memorabilia 4.1.1. It could also be seen in Bartlett 175). Plato, another disciple of Socrates, put his most extended formal eulogy into the mouth of Alcibiades in his Symposium, written about 385 but set in 416 before the Sicilian expedition when Alcibiades 
was still in good repute. Towards the end of the Symposium, a drinking party at the house of the tragic poet Agathon in which the participants each gave a speech in praise of love (ems), Alcibiades burst in and announced that the only encomium he would give was Socrates himself. Then came the confession of Alcibiades, which might be thought to be Plato's answer to Socrates' detractors. Socrates served the youth in Greece as an expert in education, which was "the greatest good for human beings". Therefore, he performed them the greatest benefaction.

This point was obvious in Confucius, the educator, although it was not mentioned directly in the Analects. In Chap. XI, Bk. 9, Yan Yuan ${ }^{83}$, one of the favourite disciples of Confucius, in admiration of the Confucius' doctrines, sighed and said,

"I looked up to them [the teachings], and they seemed to become more high; I tried to penetrate them, and they seemed to become more firm; I looked at them before me, and suddenly they seemed to be behind. The Master [Confucius], by orderly method, skillfully leads men on. He enlarged my mind with learning, and taught me the restraints of propriety..." (The Analects, Bk. IX, Ch. XI.) (颜渊喟然叹曰: “仰之弥高, 钻之弥坚; 瞻之在前, 忽焉在后。夫子循循然善诱人, 博我以文, 约我以 礼......"《论语 子罕第九.十一》)

\section{DIFFERENCES:}

While Socrates himself neither wanted to, nor really participated in politics, the educational purpose of Confucius was to shape young men into future statesmen and to realize his political ideals. Socrates distinguished himself from the sophists who were interested in success, in giving their pupils techniques, especially in the art of speaking that would enable them to get on in the world. In Plato's Apology of Socrates, the

\section{3 颜渊}


philosopher said that he stayed out of politics because of the warning of a daimonic voice which had come to him from childhood on. This voice ". . . always forbids but never commands me to do anything I am going to do." This voice, for example, said no whenever he thought of going into political life" (Jaspers, 1957, 10). He said he would long ago have been killed if he had actively participated in political life, since the philosopher believed those who publicly fight for justice always perish. In explaining that, Socrates recalled the trouble he got into by opposing unjust measures of the democracy and later of the Thirty (West, 1979, 20). Instead, Socrates believed that if someone who really fought for the just was going to preserve himself even for a short time, it was necessary for him to lead a private rather than a public life (West and West, 1998, 83). For Socrates, the purpose of education was to find truth within oneself.

In contrast, Confucius aimed at politics. The following passages from the Analects may help us understand his intention.

Zi Gong said, "There is a beautiful gem here. Should I lay it up in a case and keep it? Or should I seek for a good price and sell it?" The Master said, "Sell it! Sell it! But I would wait for one to offer the price." (The Analects, Bk. IX, Ch. XIII.)

(子贡曰: “有美玉于斯, 暳賣而藏诸? 求善贾而沽诸? ”子 曰: “沽之哉！沽之哉！我待贾者也。”《论语 子罕第九・十三》)

The Master said, "If there were (any of the princes) who would employ me, in the course of twelve months, I should have done something considerable. In three years, the government would be perfected." (The Analects, Bk. XIII, Ch. X.)

(子曰: “苟有用我者。期月而已可也, 三年有成。”(《论语 子 路第十三・十》)

For Confucius, selling for a good price would be the best for a beautiful gem rather than being kept in a case. In the similar way, holding an office in the 
government would be the best future for himself and his students, the talented men.

An overview of the historical contexts and social background from which Confucius was from would help us in understanding his ideal. As we mentioned earlier, along with the social and economic development and the increase of wealth, the middle class gradually came into being in the Chinese society, among whom were unemployed scholars, called $s h i^{84}$. They did not engage in any kind of productive activity, but depended entirely upon giving advice to feudal lords and kings for their financial support. This was the group from whom Confucius came from. During these eras in which Confucius lived, China enjoyed no political unity and suffered from the internecine warfare of small states, remnants of the once-great Zhou polity that collapsed. In such roles, shi found themselves in and out of office as the fortunes of various patron states ebbed and flowed. Confucius held office for only a short time. While out of office, veteran shi, like Confucius himself, might gather small circles of disciples- young men from shi backgrounds who wished to succeed in public life. He wished to be employed again so that he could use his political theories to bring order to the world.

For Confucius, participating in politics and obtaining status and bringing honour to oneself were not contradictory to searching for a higher meaning of life. In his idea, one's own learning is not only an individual but also a profoundly social process. Therefore, contributing to society is seen as necessary for completing the cycle of self-perfection (Lee, 1996, 38; Li 146). Furthermore, through educating individuals of society Confucius also 
attempted to bring about social reforms and put forth an ideal social order by cultivating ideal ways of life and full development of the personality of the individual. He believed in the importance of the individual to ensure the progress or reform of society (Chen, 1990, 175). So he spent much of his life-time in travelling from one state to another, receiving different classes of people to be his disciples, and teaching them, according to their capacities and environment, the way to live an ideal life and many disciples for government service.

In summary, Socratic goal of finding truth within oneself displayed more individualistic trend, whereas the Confucian view of education reflected more collective needs, whose aim was to bring good order and harmony to the society.

\section{B. The Content of Education}

\section{SIMILARITIES:}

Both Socrates and Confucius taught ethics/virtue, although their meanings and emphasis might be different. Neither of them taught crafts or work skills. Both of them acted as good models of the virtues they taught. The focuses of Socratic and Confucian conversations were about ethics, and neither of them talked about work skills or crafts.

There is an anecdote recorded in the Confucian Analects.

When Fan $\mathrm{Chi}^{85}$, one of the disciples of Confucius, requested to be taught husbandry, the Master said, "I am not so good for that as an old husbandman." Fan requested also to be taught gardening, and was answered, "I am not as good for that as an old gardener." Fan Chi having gone out, the Master said,

\footnotetext{
${ }^{85}$ 柇迟, one of the disciples of Confucius.
} 
"A small man, indeed, is Fan! If a superior man loves propriety, the people will not dare not to be reverent. If he loves righteousness, the people will not dare not to submit to his example. If he loves good faith, the people will not dare not to be sincere. Now, when these things obtain, the people from all quarters will come to him, bearing their children on their backs what need has he of a knowledge of husbandry?" (The Analects, Bk. XIII, Ch. IV.)

(樊迟请学稼, 子曰: “吾不如老农。”请学为圃。曰: ”吾不 如老圃。”樊迟出。子曰: "小人哉, 樊须也! 上好礼, 则民莫敢 不敬; 上好义, 则民莫敢不服; 上好信, 则民莫敢不用情。夫如 是, 则四方之民䘦负其子而至矣, 焉用稼? ”《论语 子路第十三. 四》)

Both philosophers had genuine interest in moral truth, or the higher ends in what one must do to be good. Socrates was interested in ethics and conducts of life, for example, the concept of evil and just, and how to lead a good life. He had conversations and debates with people about various questions relating to politics, pleasure and knowledge. Often these were great questions of life, like "How can we find truth?", "What does it mean to know something?", and "How should human beings live their lives?" etc. As Socrates was characterized by these moral preoccupations, Aristotle described him in a brief phrase as "concerned with the moral virtues" ${ }^{86}$. In their memoirs, the other disciples of Socrates, Xenophon and Plato represent him as patriotic and law-abiding. For Xenophon, Socrates was the best and happiest of men: pious, just, self-controlled, and sensible (Memoirs of Socrates, I, 11). After recounting his death in his dialogue in Phaedo, Plato pronounced Socrates to have been of all whom they knew in their time, the best, the wisest and the most upright man (Phaedo, 118). Plato's tribute culminated in the superlative form of the adjective dikaios, which was related to the noun dikaiosyne, justice or righteousness, the fourth and sum of the cardinal virtues of the ancient world

\footnotetext{
${ }^{86}$ C.f. Joint Association of Classical Teachers' Greek Course. The World of Athens: An Introduction to Classical Athenian Culture. Cambridge: Cambridge UP, 1984. Page 294.
} 
embracing the other three, courage, wisdom and temperance. In his life and in his manner of dying, Socrates embodied for his admirers the perfection of the philosophic spirit (Sowerby, 2009, 150).

The similar traits could be found in Confucius. For the Chinese philosopher, the practice of right living is the highest of all arts, and other arts are of minor importance. Confucius advocated ethics as human-heartedness $\left(r e n^{87}\right)$ and righteousness $\left(y i^{88}\right)$. He also aimed to train gentlemen (junzi ${ }^{89}$, often translated as the "superior man") who carried themselves with grace, spoke correctly, and demonstrated integrity at high levels; while he strongly disliked the sycophantic "petty men" ( $x$ iao $\operatorname{ren}^{90}$, often translated as the "small man", or the "mean man"), whose clever talk and pretentious manner won them an audience. The contrast can be seen in numerous passages in the Analects:

The Master said, "The superior man thinks of virtue; the small man thinks of comfort. The superior man thinks of the sanctions of law; the small man thinks of favours which he may receive." (The Analects, Bk. IV, Ch. XI.)

(子曰: “君子怀德, 小人怀土; 君子怀刑, 小人怀惠。”《论 语 里仁第四: 十一》

The Master said, "The mind of the superior man is conversant with righteousness; the mind of the mean man is conversant with gain." (The Analects, Bk. IV, Ch. XVI.)

(子曰: “君子喻于义, 小人喻于利。” 《论语 里仁第四- 十 六》)

The Master said, "The superior man is satisfied and composed; the mean man is always full of distress." (The Analects, Bk. VII, Ch. XXXVII.)

\footnotetext{
87 仁

88 义

89 君子

90 小人
} 


\section{十七》) \\ （子曰: “君子坦荡荡，小人长戚戚。”《论语 述而第七·三}

"...The relation between superiors and inferiors is like that between the wind and the grass. The grass must bend, when the wind blows across it." (The Analects, Bk. XII, Ch. XIX.)

(“...君子之德风, 小人之德草, 草上之风, 必偃。”《论语 颜 渊第十二・十九》)

The Master said, "The superior man seeks to perfect the admirable qualities of men, and does not seek to perfect their bad qualities. The mean man does the opposite of this." (The Analects, Bk. XII, Ch. XVI.)

(子曰: “君子成人之美, 不成人之恶。小人反是。”《论语 颜渊第十二・十六》)

The Master said, "What the superior man seeks, is in himself. What the mean man seeks, is in others." (The Analects, Bk. XV, Ch. XXI.)

(子曰: “君子求诸己, 小人求诸人。” 《论语 卫灵公第十 五·二十一》)

As shown above, the superior man and the mean man differed in their characters and behaviour patterns. Confucius called on people to act as the superior man, which was the ideal of high moral standards.

Furthermore, if we examine further, we can find that the virtues for both philosophers share some in common. For example, both of them promoted the virtue of frugality and stressed a simplistic way of living. Socrates' frugal and self-controlled life was well known. His frugal or ascetic way of life, his bare-footedness and the capacity to endure pain-these became features peculiar to Socrates in the depiction of Plato and Xenophon, and were even shown in Aristophanes' Clouds.

In the similar way, we could also find Confucius' preference to simple way of living in the Analects: 
The Master said, "Extravagance leads to insubordination, and parsimony to meanness. It is better to be mean than to be insubordinate." (The Analects, Bk. VII, Ch. XXXVI.)

(子曰: “奢则不孙, 俭则固。与其不孙也, 宁固。”《论语 述 而第七· 三十六》)

The Master said, "With coarse rice to eat, with water to drink, and my bended arm for a pillow; I have still joy in the midst of these things. Riches and honours acquired by unrighteousness, are to me as a floating cloud." (The Analects, Bk. VII, Ch. XVI.)

(子曰: “饭疏食饮水, 曲肱而枕之, 乐亦在其中矣。不义而富 且贵，于我如浮云。”《论语 述而第七・十六》)

In addition to their similar views in simple life, both philosophers also emphasized on the importance of self-knowledge. They shared view that the educated man is wise when he knows himself. The highest knowledge is possessed by that individual who truly knows himself. This knowledge constitutes ultimate wisdom. It enables man to act in a virtuous manner at all times, because he knows what will bring him true happiness. The oracle at Delphi declared that no one was wiser than Socrates, which Socrates interpreted as meaning that he alone was aware of his own ignorance. "Nonknowledge guides me over and over again to the point where I am myself because I recognize the good as the true, and where it is entirely up to me to live in accordance with it" (Jaspers, 1957, 10). In his life Socrates advocated qualities like being 'prudent', 'discreet', 'sensible', 'chaste', 'law-abiding', 'modest', 'moderate', and 'disciplined'. At heart it implies restraint and acknowledgement of one's own limitations, which was perfectly captured by the two famous mottoes inscribed over the entrance to the temple of Apollo at Delphi: 'meden agan' ('nothing in excess') and 'gnothi seauton' ('know yourself'). At heart it implies the acknowledgement of one's own limitations. 
Confucius also attached importance to self-knowledge, especially in learning. He never thought himself in possession of complete knowledge and never thought such knowledge possible:

The Master said, "You, shall I teach you what knowledge is? When you know a thing, to hold that you know it; and when you do not know a thing, to allow that you do not know it - this is knowledge." (The Analects, Bk. II, Ch. XVII.)

(子曰: “由! 诲女知之乎? 知之为知之, 不知为不知, 是知 也。”《论语为政第二: 十七》)

Knowing his limitations in learning, Confucius was a humble and cautious teacher and scholar. This stage of "knowing what you know and knowing what you don't know" has been regarded as a very high level of attainment in learning in the Chinese academic tradition.

Self-knowledge led to self-examination. Socrates was well aware of his ignorance. He emphasized on self-examination so as to avoid pretended self-knowledge or ignorance. Plato's Apology of Socrates, he confessed "One of you, O human beings, is wisest, who, like Socrates, has become cognizant that in truth he is worth nothing with respect to wisdom" (West and West, 1998, 72). Self-examination brings self-realization, and only with this awareness can we control ourselves and reduce our faults. In this perspective, Confucius is more specific and explicit. He said, "The cautious seldom err." (The Analects, Bk. IV, Ch. XXIII.) (子曰: “以约失之者, 鲜矣。”《论语 里仁第四- 二十三》) . He also expressed this idea through Zengzi ${ }^{91}$, his student: 
have I been untrustworthy? Have not practiced what I have preached?" (The Analects, Bk. I, Chap. IV.)

(曾子曰: “吾日三省吾身: 为人谋而不忠乎? 与朋友交而不 信乎? 传不习乎?”《论语 学而第一四》).

Similar passages dealt with self-examination and reflection could be

found elsewhere in the Analects:

The Master said, "When we see men of worth, we should think of equalling them; when we see men of a contrary character, we should turn inwards and examine ourselves." (The Analects, Bk. IV, Ch. XVII.) 四: 十七》)

(子曰: “见贤思齐焉, 见不贤而内自省也。”《论语 里仁第

The Master said: "It's all over! I have not yet met someone who can see his own faults and correct them within himself." (The Analects, Bk. V, Ch. XXVII.)

(子曰: “已矣乎! 吾未见能见其过而内自讼者也。”《论语 公 冶长第五: 二十七》)

The Master said, "He who censures himself strongly and others lightly will keep himself far away from resentment." (The Analects, Bk. XV, Ch. XV.)

(子曰: “躬自厚而薄责于人，则远怨矣。”《论语 卫灵公第 十五・十五》)

Moreover, both philosophers came to agreement on the relationship between speech and deeds/action, i.e. deeds was more important than speech. In Xenophon's Memorabilia, Socrates claimed, "I show it rather by deed. Or is it not your opinion that one's deed is more worthy testimony than one's speech?" (130) In this regard, Confucius had similar views: The superior man is slow in words and speedy in action; he is careful not to allow his words outshine his deeds-first act, then speak accordingly.

The Master said, "The superior man wishes to be slow in his speech and earnest in his conduct." (The Analects, Bk. IV, Ch. XXIV.)

(子曰: “君子欲讷于言，而敏于行。”《论语 里仁第四・二 十四》)

The Master said, "The superior man is modest in his speech, but exceeds in his actions." (The Analects, Bk. XIV, Ch. XXVII.) 


\section{七》) \\ (子曰: “君子耻其言而过其行。”《论语 宪问第十四・二十}

\section{DIFFERENCES:}

Similar views of two philosophers mirrored their similar opinions on the practice of right life, or to put it simply, what is good. However, different cultural background certainly resulted in different perspectives in their conversation topics. Socrates was interested in ethics and conducts of life, for example, the concept of justice and how to lead a good life. For Socrates, virtues and the nature of the good and happy life include prudence, moderation, temperate living, love of toil, piety, just truth, and the good of the soul, etc.

In comparison, the virtues promoted by Confucius were loyalty, filial piety, proper conduct, trustworthiness, self-discipline, modesty/humbleness, human-heartedness and righteousness etc., which constituted major parts in Confucian Analects. Among them, many were absent in Socratic discussion of ethics. In this paper, major concepts of filial piety (xiao $\left.{ }^{92}\right)$, loyalty $\left(\right.$ zhong $\left.^{93}\right)$, and rules of proper conduct $\left(\mathrm{Ii}^{94}\right)$ are selected for further discussion.

\section{Filial Piety (xiao)}

For Confucius, filial piety was the right conduct toward parents: we should obey and serve our parents in life, bury them properly after death, and thereafter sacrifice to them according to propriety.

The Master said, "While his parents are alive, the son may not go abroad to a distance. If he does go abroad, he must have a fixed place to which he goes." (The Analects, Bk. IV, Ch. XIX.) 


\section{九》) \\ (子曰: “父母在, 不远游。游必有方。”《论语 里仁第四- 十}

Meng $\mathrm{Yi}^{95}$ asked what filial piety was. The Master said, "It is not being disobedient." Soon after, as Fan $\mathrm{Chi}^{96}$ was driving him, the Master told him, saying, "Meng-sun (Meng Yi) asked me what filial piety was, and I answered him, - 'not being disobedient." Fan Chi said, "What did you mean?" The Master replied, "That parents, when alive, be served according to propriety; that, when dead, they should be buried according to propriety; and that they should be sacrificed to according to propriety." (The Analects, Bk. II, Ch. V.)

(孟懿子问孝。子曰: “无违。”焚迟御，子告之曰: “孟孙 问孝于我, 我对曰: “无违”。”樊迟曰: “何谓也? ”子曰: “生, 事 之以礼; 死, 葬之以礼, 祭之以礼。” 《论语为政第二: 五》 )

Zeng said, "Let there be a careful attention to perform the funeral rites to parents, and let them be followed when long gone with the ceremonies of sacrifice - then the virtue of the people will resume its proper excellence." (The Analects, Bk. I, Ch. IX.)

(曾子曰: “慎终追远, 民德归厚矣!”《论语 学而第一九》)

The Master said, "If the son for three years does not alter from the way of his father, he may be called filial." (The Analects, Bk. IV, Ch. XX, also in Bk. I, Ch. XI.)

(子曰: “三年无改于父之道, 可谓孝矣。”《论语 里仁第四. 二十》、《论语 学而第一:十一》)

The Master said, "Observe what a person has in mind to do when his father is alive, and then observe what he does when his father is dead. If for three years he does not alter from the way of his father, he may be called filial." (The Analects, Bk. I, Ch. XI.)

（学而：子曰: “父在, 观其志; 父没, 观其行; 三年无改于 父之道, 可谓孝矣。”《论语 学而第一:十一》)

For Confucius, however, it is not enough to only feed our parents

while they are alive — "if respect is absent, wherein should we differ from the

beasts?" (cf. The Analects, Bk. II, Ch. VII.)

$\mathrm{Zi} \mathrm{Xia{ } ^ { 9 7 }}$ asked what filial piety was. The Master said, "The difficulty is with the countenance. If, when their elders have any troublesome affairs, the young take the toil of them, and if, when the young have wine and food, they set them before their elders,

95 孟懿, one of the disciples of Confucius.

96 枆迟

97 子夏 
is THIS to be considered filial piety? " (The Analects, Bk. II, Ch. VIII.)

(子夏问孝。子曰: “色难! 有事, 弟子服其劳; 有酒食, 先 生馔。曾是以为孝乎?” 《论语为政第二:八》)

$\mathrm{Zi} \mathrm{You}{ }^{98}$ asked what filial piety was. The Master said, "The filial piety nowadays means the support of one's parents. But dogs and horses likewise are able to do something in the way of support; without reverence, what is there to distinguish the one support given from the other?" (The Analects, Bk. II, Ch. VII.)

(子游问孝。子曰: “今之孝者, 是谓能养。至于犬马, 皆能 有养; 不敬, 何以别乎? ”《论语为政第二·七》)

Filial piety, as one of the important notions in the Analects, has its roots in the Chinese history and society. In considering Confucian views of the good society, Benjamin Schwartz notes how the ideal family is "the ultimate source of all those values which humanize the relations of authority and hierarchy which must exist in any civilized society" $(1985,70)$. Unlike the small size of the Greek city state which was small enough for a limited form of democracy to emerge among male citizens, the size and scope of the Chinese empire was quite different. For Confucius, "it is precisely in the family that humans learn those virtues which redeem the society" and that "authority comes to be accepted and exercised, not through reliance on physical coercion but through the binding power of religious, moral sentiments based on kinship ties" $(1985,70)$.

Filial piety, which has been regarded as the moving force of all virtues in Confucian ethics, has a very much wider significance. For Confucius, the society should be consisted of a sense of order, vertical and horizontal relation between obligations to the group, and a preference for harmony and cooperation. In his view, an individual is perceived as being a part different

\section{8 子游}


overlapping social networks and there are highly defined rights and obligations attached to the relative position each individual possesses in such networks (Gao and Schachler, 2004, 45). Confucius emphasized the family as the base of a person's operation and also as an ethical unit of society. At the top of this family relation hierarchy ethical system is parents, or the representative, the father; and the concept of filial piety defines the relationship between parents and children. If the whole country is compared to one big family, then the emperor/ruler acts as the parent, and the quality of faithfulness or loyalty is needed.

\section{Loyalty (zhong)}

Socratic devotion of soul was to the gods, and Socrates was "so pious as to do nothing without the gods' judgment" (Memorabilia/Xenophon 149), whereas Confucian devotion was to the emperor/ruler:

The duke Ding asked how a prince should employ his ministers, and how ministers should serve their prince. Confucius replied, "A prince should employ his minister according to the rules of propriety; ministers should serve their prince with loyalty." (The Analects, Bk. III, Ch. XIX.)

(定公问: “君使臣，臣事君，如之何？” 孔子对曰: “君使臣 以礼，臣事君以忠。”《论语 八佮第三:十九》)

Ji Kang ${ }^{99}$ asked how to cause the people to reverence their ruler, to be faithful to him, and to go on to nerve themselves to virtue. The Master said, "Let him (the ruler) preside over them with gravity; then they will reverence him. Let him be final and kind to all; then they will be faithful to him. Let him advance the good and teach the incompetent; then they will eagerly seek to be virtuous." (The Analects, Bk. II, Ch. XX.)

（季康子问：“使民敬、忠以劝，如之何？”子曰: “临之以 庄则敬, 孝慈则忠, 举善而教不能, 则劝。”《论语 为政第二: 二 $+\gg)$

If the relations between old and young may not be neglected, how is it that he sets aside the duties that should be 
observed between sovereign and minister? (The Analects, Bk.

XVIII, Ch. VII.)

(长幼之节, 不可废也; 君臣之义, 如之何其废之? 《论语 微 子第十八・七》)

To summarize, in Confucian views, similar to the relations between old and young, the duties between the emperor and his ministers should be observed: the emperor should employ his minister according to the rules of propriety; ministers should serve their prince with loyalty.

\section{Rules of Proper Conduct (li)}

The Chinese word li, as Lin Yutang ${ }^{100}$ has pointed out, cannot be rendered by an English word; rather, it has many meanings. According to him, on one extreme, it means 'ritual', 'propriety'; and in a generalized sense, it simply means 'good manners in its highest philosophic sense, an ideal social order with everything in its place, and particularly a rationalized feudal order which was breaking down in Confucius' days. H. H. Dubs translated li as "the rules of proper conduct", which is comparatively expressive and comprehensive, including the rules of proper conduct of "propriety" or "good manners", in ceremonies, rites, moral and religious institutions, social life, or in a rationalized feudal order. Therefore, this way of translation is adopted by the present writer in this paper.

$L i$, or the rules of proper conduct, is believed to have been recorded in the ancient literature and handed down from the ancient "sage kings", which aims to give coherence and order to societies (Chen, 1990, 84). Confucius set forth the li as an ideal social order. He observed them, collected them, 
formulated and arranged them. His vision embraced the right way of walking,

greeting, receiving gifts, behaving in company, always in accordance with the

particular situation:

When the Prince summoned him [Confucius] to receive a visitor, his expression seemed to change, and his legs as it were bent under him. As he saluted those who stood with him, on the right hand or the left as occasion required, his robe in front and behind hung straight and undisturbed; and, as he hastened forward, it was as if with outstretched wings. (The Analects, Bk. X, Ch. III.)

(君召使摈, 色勃如也, 足躓如也。揖所与立, 左右手。衣 前后, 襜如也。趋进, 翼如也。宾退, 必复命曰: “宾不顾矣。” 《论语 乡党第十·三》)

When he [Confucius] entered the palace gate, he seemed to bend his body, as if it were not sufficient to admit him. When he was standing, he did not occupy the middle of the gateway; when he passed in or out, he did not tread upon the threshold. When he was passing the vacant place of the prince, his countenance appeared to change, and his legs to bend under him, and his words came as if he hardly had breath to utter them. He ascended the reception hall, holding up his robe with both his hands, and his body bent; holding in his breath also, as if he dared not breathe. When he came out from the audience, as soon as he had descended one step, he began to relax his countenance, and had a satisfied look. When he had got the bottom of the steps, he advanced rapidly to his place, with his arms like wings, and on occupying it, his manner still showed respectful uneasiness. (The Analects, Bk. X, Ch. IV.)

(入公门, 鞠躬如也, 如不容。立不中门, 行不履阈。过位, 色勃如也, 足躍如也, 其言似不足者。摄齐升堂, 鞠躬如也, 屏 气似不息者。出, 降一等, 逞颜色, 怡怡如也。没阶趋, 翼如也。 复其位, 踧踖如也。《论语 乡党第十・四》）

When the prince sent him [Confucius] a gift of cooked meat, he would adjust his mat, first taste it, and then give it away to others. When the prince sent him a gift of undressed meat, he would have it cooked, and offer it to the spirits of his ancestors. When the prince sent him a gift of a living animal, he would keep it alive. When he was in attendance on the prince and joining in the entertainment, the prince only sacrificed. He first tasted everything. When he was ill and the prince came to visit him, he had his head to the east, made his court robes be spread over him, and drew his girdle across them. When the prince's order called him, without waiting for his carriage to be yoked, he went at once. (The Analects, Bk. X, Ch. XIII.)

(君赐食, 必正席先尝之; 君赐腥, 必熟而荐之; 君赐生, 必畜之。侍食于君, 君祭, 先饭。疾, 君视之, 东首, 加朝服, 拖绅。君命召, 不俟驾行矣。《论语 乡党第十・十三》) 
In Confucian concept of $l i$, the behavior rules are the unceasing education of all men. They are the forms which create the right frame of mind in all spheres of existence: earnestness, confidence, and respect. They guide men through something universal which is acquired by education and becomes second nature, so that the individual comes to experience the universal not as a constraint but as his own being ${ }^{101}$. Li was held to be set up by the ancient sage kings and rulers, for the prevention of crimes and for the encouragement of good conduct. Chen $(1990,249)$ also explained the origin and functions of li. According to him, to ensure the success of li, the ancient sage sovereigns lived up to that standard themselves, selecting the best men in their country to fill offices, and educating the people to observe li. So what the government of the later generations should do was simply to put $l i$ into practice and follow the examples of the sage-kings and rulers $(1990,249)$.

The promotion of proper conduct also has its social and historical reasons. During the feudal times in which Confucius lived, there was a complete lack of law in the ancient Chinese society and feudal wars were prevalent. Anarchy impaired the society, and pessimism about the future was common. In these circumstances, Confucius saw the need for organized rules of conduct and clear patterns of behavior for everyone. In his view, the appropriate application of behavior rules between the ruler and minister, parent and child, the perfect execution of guest-host etiquette, and the correct performance of court ritual all serve a common end-they regulate and maintain order. By offering these social patterns, Confucius attempted to regulate social relationships and bring harmony and good order to the society.

\footnotetext{
${ }^{101}$ Jaspers $(1957,45)$ expressed similar view on this point.
} 
Another important factor that caused the formation of these social patterns of filial piety (xiao), loyalty (zhong), and rules of proper conduct (li) were the power distance between the superior and the inferior in the ancient Chinese society:

Duke Jing of Qi asked Confucius about government. Confucius replied: "Let the ruler be a ruler, minister be a minister, father be a father, son be a son." (The Analects, Bk. XII, Ch. XI.)

(齐景公问政于孔子。孔子对曰: “君君, 臣臣, 父父, 子子。” 《论语 颜洲第十二:十一》)

If the relations between old and young may not be neglected, how is it that he sets aside the duties that should be observed between sovereign and minister? (The Analects, Bk. XVIII, Ch. VII.)

(长幼之节, 不可废也; 君臣之义, 如之何其废之? 《论语 微 子第十八・七》)

"Let the ruler be a ruler, minister be a minister, father be a father, son be a son." This explains what happens in the hierarchical political and social conception of Confucius-in the government administration, the ruler, the superior, should treat the minister, the inferior, with the rules of propriety; while the minister should serve the ruler with loyalty. Within the smaller unit of family, the father, the superior, should behave with affection with his son, the inferior; while the son should serve his father based on filial piety. In these ideal hierarchies of power between ruler and subject, parent and child, it would be easier to understand why family is the all-important unit in consolidating this system and filial piety (xiao) acts as the paramount example of harmonious social order, where reverence $\left(j i n g^{102}\right)$ is the key quality. Together with other moral values that Confucius advocated, namely loyalty (zhong), the rules of 
proper conduct $(I i)$, benevolence $\left(r e n^{103}\right)$, righteousness $\left(y i^{104}\right)$, trustworthiness $\left(x n^{105}\right)$, etc, these were the practical ethics that help to give coherence to the society.

Socrates asserted that the highest good for any human being is happiness. Sowerby $(2009,146)$ argues that the doctrine which seems to have been the ground of Socrates' actual beliefs is expressed in the proposition that virtue (arete, excellence) is knowledge. Whatever action a man chooses is motivated by his desire for happiness. The wise man who knows what is good and what conduces to human happiness will do what is good and conduces to human happiness. Wrong actions are a result of a faulty perception of what conduces to true human good. Hence it is possible to say that no one willingly does wrong, since man chooses an action according to what he thinks will bring him the greatest happiness. Therefore the more a man knows, the greater his ability to reason out the correct choice and to choose those actions which truly bring happiness to him. His ethical concern did not of course lead Socrates to prescribe rules for good conduct, but was directed towards the increase of self-awareness as a prerequisite to the health and well-being of the psyche (spirit or soul, including the mind). Socrates showed more concern on the individual's need and the health of one's own soul.

In comparison, Confucius called for a personal cultivation that involves achieving inner equanimity and outer integrity and responsibility to society. The moral values Confucius advocated came from the need of social hierarchy and his idea of social rules of conduct. He offered new social patterns and the 
ways in which human beings may live together in harmony and good order. For Confucius, only through the virtues of the community did the individual become a man. Therefore, Confucius' moral education focused more on social rather than individual dimension.

\section{The Teaching/Education Process}

\section{SIMILARITIES:}

1. Both Socrates and Confucius were similar in the selection of students/audiences-their talks were open to everyone, although women were excluded in both cases. In his life, Socrates was willing to converse openly with everyone. His disciples learned from him and extended his ways, but regrettably none of the later philosophical schools inherited this tendency to openly associate with the regular citizens.

Popular Education has the detailed description in Confucius, who provided education to virtually all those who wanted to learn with no discrimination of class or type:

The Master said, "In teaching there should be no distinction of classes." (The Analects, Bk. XV, Ch. XXXIX.)

(子曰: “有教无类。”《论语 卫灵公第十五・ 三十九》)

Confucius has been supposed to be the first or at least the greatest advocator of his time in China of education opportunity for all. He was willing to teach anyone, whatever their social standings, as long as they were eager to learn. In education there should be no class distinction, he said. None had ever come to him without receiving instruction, from the very poorest upwards-and 
stupid people as well as clever ones. He never refused to teach anyone who came to him for learning, even if they had but a very small amount for fees:

The Master said, "From the man bringing his bundle of dried meat for my teaching upwards, I have never refused instruction to anyone." (The Analects, Bk. VII, Ch. VII.) 七》)

(子曰: “自行束修以上, 吾未尝无诲焉。”《论语 述而第七·

The children, too, who came from disreputable villages and were looked down upon by his disciples, were warmly received by the Master:

It was difficult to talk (profitably and reputably) with the people of Hu Xiang, and a lad of that place having had an interview with the Master, the disciples doubted. The Master said, "I admit people's approach to me without committing myself as to what they may do when they have retired. Why must one be so severe? If a man purifies himself to wait upon me, I receive him so purified, without guaranteeing his past conduct." (The Analects, Bk. VII, Ch. XXIX.)

(互乡难与言, 童子见, 门人惑。子曰: “与其进也, 不与其 退也, 唯何甚! 人洁己以进, 与其洁也, 不保其往也。”《论语 述 而第七・二十九》)

The wide range of audience reflected the open mind and the insight of both Socrates and Confucius in education. It was rare both in the West and East in the ancient time.

\section{Both philosophers adopted different methods in teaching different students}

Socrates did not approach everyone, that is, every type of person, in the same way (Memorabilia/Xenophon $x x i$ ). Socrates possessed the capacity to speak differently to different audiences. Likewise, Confucius offered different answers to the same question that were raised from different students. Here is an example recorded in the Analects: 
Zi Lu ${ }^{106}$ asked whether he should immediately carry into practice what he heard. The Master said, "There are your father and elder brothers to be consulted -why should you act on that principle of immediately carrying into practice what you hear?" Ran You ${ }^{107}$ asked the same, whether he should immediately carry into practice what he heard, and the Master answered, "Immediately carry into practice what you hear." Gong Xi Hua ${ }^{108}$ said, "You [Zi Lu] asked whether he should carry immediately into practice what he heard, and you, the Master said, 'There are your father and elder brothers to be consulted.' Qiu [Ran You] asked whether he should immediately carry into practice what he heard, and you said, 'Carry it immediately into practice.' I, Chi [Gong Xi Hua], am perplexed, and venture to ask you for an explanation." The Master said, "Qiu [Ran You] is retiring and slow; therefore I urged him forward. You [Zi Lu] has more than his own share of energy; therefore I kept him back." (The Analects, Bk. XI, Ch. XXII.)

(子路问: “闻斯行诸？”子曰: “有父兄在，如之何其闻斯行 之? ”苒有问: “闻斯行诸? ”子曰: “闻斯行之。”公西华曰: “由也 问闻斯行诸，子曰'有父兄在”; 求也问闻斯行诸，子曰’闻斯行之'。 赤也惑, 敢问。”子曰: “求也退, 故进之; 由也兼人, 故退之。” 《论语 先进第十一: 二十二》)

As drawn above, different ways in education were employed when both philosophers spoke to different audience, although the emphasis was not the same: Socrates would use a variety of ways to question, while Confucius emphasized more on different answers.

\section{DIFFERENCES:}

\section{Not to teach vs. to teach}

The two philosophers differed greatly in their education process.

First of all, Socrates never claimed to teach. In Plato's Apology of Socrates, the Greek philosopher argued that "I have never been anyone's teacher" (86). The same period saw the growth of a new kind of professional teacher throughout Greece. These men were called sophists, a name derived from the

\footnotetext{
106 子路

107 由有

108 公西华
} 
word for wisdom or skill, sophia. They moved from city to city, giving lessons in such things as mathematics, politics and the art of public speaking, designed to be useful for the rising political classes (Sowerby, 2009, 46). In Plato's description, Socrates deliberately made distinction between himself and the sophists who were interested in giving their pupils techniques, especially in the art of speaking.

In contrast, Confucius openly admitted what he did was "to teach":

The Master, by orderly method, skillfully leads men on. He enlarged my mind with learning, and taught me the restraints of propriety $^{109}$. (The Analects, Bk. IX, Ch. XI.)

(夫子循循然善诱人, 博我以文, 约我以礼《论语 子罕第九 -十一》)

... [Confucius] teach others without weariness. (The Analects, Bk. VII, Ch. II \& XXXIV.)

(......诲人不倦《论语 述而第七·二》, 《论语 述而第七· 三十四》）

Socrates adamantly insisted he was not a teacher and refused all his life to take money for what he did. In their introduction to Plato's Symposium, Howatson \& Sheffield $(2008,86)$ remarked: "He [Socrates] exerted considerable influence on the rich young men, future politicians, with whom he associated, although he never claimed to teach, nor did he accept fees." In another work by Plato, Apology of Socrates, the philosopher claimed before his death: "I do not converse only when I receive money, and not when I do not receive it" (86). The reason for Socrates in refraining from charging money could be found in Xenophon's Memorabilia, where Socrates explained he was attending to his freedom; "and he called those who take pay for their association enslavers of themselves, because of its being necessary that

\footnotetext{
${ }^{109}$ It was from Yan Hui's comments on his master, Confucius.
} 
they converse with those from whom they took their pay" (4). Sowerby $(2009,147)$ held this refusal of the tuition was also due to the divine mission of Socrates: "Certainly there is a gulf between the practical aim of worldly success expressed by Protagoras and the divine mission of Socrates. In method they differed too. The sophists gave lectures in schools for a fee; Socrates did not give lectures nor did he set up a school or take fees".

In contrast, as a true teacher, Confucius accepted the tuition fee, although it could be as little as a bundle of dried meat:

The Master said, "From the man bringing his bundle of dried meat for my teaching upwards, I have never refused instruction to anyone." (The Analects, Bk. VII, Ch. VII.)

(子曰: “自行束修以上, 吾未尝无诲焉。”《论语 述而第七. 七》)

Confucius accepted fees and he also comprehensive teaching system. His teaching was comprehensive and systematic. First, Confucius provided the text-books by selecting ancient texts, documents, songs, oracles, codes of manners and customs, and reworking them with a view to truth and effectiveness. He believed that the most important lessons for gaining such a moral education were to be found in the canonical Book of Songs, where poems were both beautiful and good. Thus Confucius placed the text first in his curriculum and frequently quoted and explained its lines of verse. For this reason, the Analects is also an important source for Confucius' understanding of the role poetry and art generally play in the moral education of gentlemen and in the reformation of society. Besides, Confucius also taught ritual, music, archery, chariot-riding, calligraphy, and computation to his students. 
methods to the various needs and capacities of his students. He knew each of his students very well:

Ji Kang ${ }^{110}$ asked about Zhong You ${ }^{111}$, one of Confucius' disciples, whether he (Zhong You) was fit to be employed as an officer of government. The Master said, "You [Zhong You] is a man of decision; what difficulty would he find in being an officer of government?" Kang asked, "Is $\mathrm{Ci}^{112}$ [another disciple] fit to be employed as an officer of government?" and was answered, "Ci is a man of intelligence; what difficulty would he find in being an officer of government?" And to the same question about Qiu ${ }^{113}$ [another disciple] the Master gave the same reply, saying, "Qiu is a man of various abilities." (The Analects, Bk. VI, Ch. VIII.)

(季康子问: “仲由可使从政也与？”子曰: “由也果，于从政 乎何有？”曰: “赐也, 可使从政也与？”曰: “赐也达, 于从政乎 何有?”曰: “求也, 可使从政也与? ”曰: “求也艺, 于从政乎何 有?”《论语 雍也第六・八》)

Confucius recognized the principle of individual differences and adjusted

his teaching methods to the needs, conditions, and capacities of his students.

$\mathrm{Zi} \mathrm{Lu}$ asked whether he should immediately carry into practice what he heard. The Master said, "There are your father and elder brothers to be consulted -why should you act on that principle of immediately carrying into practice what you hear?" Ran You asked the same, whether he should immediately carry into practice what he heard, and the Master answered, "Immediately carry into practice what you hear." Gong Xi Hua said, "You [Zi Lu] asked whether he should carry immediately into practice what he heard, and you, the Master said, 'There are your father and elder brothers to be consulted.' Qu [Ran You] asked whether he should immediately carry into practice what he heard, and you said, 'Carry it immediately into practice.' I, Chi [Gong Xi Hua], am perplexed, and venture to ask you for an explanation." The Master said, "Qiu [Ran You] is retiring and slow; therefore I urged him forward. You [Zi Lu] has more than his own share of energy; therefore I kept him back." (The Analects, Bk. XI, Ch. XXII.)

(子路问: “闻斯行诸？” 子曰: “有父兄在，如之何其闻斯行 之? ”囘有问：“闻斯行诸？”子曰: “闻斯行之。”公西华曰: “由也 问闻斯行诸, 子曰”有父兄在”; 求也问闻斯行诸, 子曰”闻斯行之'。 
赤也惑, 敢问。”子曰: “求也退, 故进之; 由也兼人, 故退之。”

《论语 先进第十一: 二十二》)

Confucius employed various teaching methods. He was good in relating of new ideas to familiar ideas, or of the unknown to the known (c.f. Chen, 1990, 385). Confucius recognized this principle in his teaching: he drew extensively upon the previous knowledge of his students by frequent reference to the well-known historical events of the past, such as those connected with $\mathrm{Yao}^{114}$, Shun ${ }^{115}, \mathrm{Yu}^{116}$, the emperor of Shang Tang ${ }^{117}$, Zhou Wen ${ }^{118}$, Zhou Wu ${ }^{119}$, etc; and to the famous books that existed in his days like The Book of History, The Book of Poetry, and The Book of Rites. He made effective use of the similes, the metaphors, the analogies, and the parables. The following are some examples:

When he (Confucius) was standing by a stream with his disciples, he taught them the lesson of "change" by comparing it with the ever-changing and yet ever-the-same stream of water which was passing by them, "never ceasing day or night."

The Master standing by a stream, said, "It passes on just like this, not ceasing day or night!" (The Analects, Bk. IX, Ch. $\mathrm{XVII.)}$ 第九・十七》)

(子在川上, 曰: “逝者如斯夫! 不舍昼夜。”《论语 子罕

One night when he saw the bright north solar star shine like a prince among the constellations, he said to his disciples, "He who exercises 
government by means of virtue may be compared to the north polar star, which keeps its place and all the stars turn towards it."

The Master said, "He who exercises government by means of his virtue may be compared to the north polar star, which keeps its place and all the stars turn towards it." (The Analects, Bk. II, Ch. I.)

子曰: “为政以德，譬如北辰，居其所而众星共之。” 《论语 为政第二:一》)

He also analogized the influence of the character of the superior to the inferior with the wind to the grass. "The relation between superiors and inferiors", he said, "is like that between the wind and the grass. The grass must bend, when the wind blows across it."

Ji Kang asked Confucius about government, saying, "What do you say to kill the unprincipled for the good of the principled?" Confucius replied, "Sir, in carrying on your government, why should you use killing at all? Let your evinced desires be for what is good, and the people will be good. The relation between superiors and inferiors is like that between the wind and the grass. The grass must bend, when the wind blows across it." (The Analects, Bk. XII, Ch. XIX.)

季康子问政于孔子曰: “如杀无道, 以就有道, 何如? ”孔子 对曰: “子为政，焉用杀？子欲善，而民善矣。君子之德风，小人 之德草。草上之风, 必偃。”《论语 颜渊第十二: 十九》)

Confucius was fond of using concrete everyday incidents for his teaching, and he was skilful in drawing lessons from the concrete to the abstract, from know to unknown, and from near to the more remote. Other common objects like the plants, the flowers, the hills etc, were all taken as his object-lessons:

The Master said, "There are cases in which the blade springs, but the plant does not go on to flower! There are cases where it flowers but no fruit is subsequently produced! " (The Analects, Bk. IX, Ch. XXII.)

(子曰; “苗而不秀者有矣夫! 秀而不实者有矣夫! ”《论语 子 罕第九・二十二》)

The Master said, "The prosecution of learning may be compared to what may happen in raising a mound. If there want but one basket of earth to complete the work, and I stop, the stopping is my own work. It may be compared to throwing down the earth on the level ground. Though but one basketful is 
thrown at a time, the advancing with it is my own going

forward. " (The Analects, Bk. IX, Ch. XIX.)

(子曰: “譬如为山, 未成一箩, 止, 吾止也; 譬如平地, 虽

覆一簤, 进, 吾往也。”《论语 子罕第九・十九》)

As an excellent teacher, Confucius knew his students, the texts and teaching methods very well. To his students, he never discoursed at length on a subject. Instead, he posed questions, cited passages from the classics, or used apt analogies, and waited for his students to arrive at the right answers. "Only one who bursts with eagerness do I instruct: only one who bubbles with excitement, do I enlighten. If I hold up one corner and a man cannot come back to me with the other there, I do not continue the lesson" (c.f. the Analects, Bk. VII, Ch. VIII.).

The Master said, "I do not open up the truth to one who is not eager to get knowledge, nor help out any one who is not anxious to explain himself. When I have presented one corner of a subject to any one, and he cannot from it learn the other three, I do not repeat my lesson." (The Analects, Bk. VII, Ch. VIII.)

(子曰: “不愤不启, 不悱不发, 举一隅不以三隅反, 则不复 也。”《论语 述而第七・八》)

Another principle Confucius often used in teaching was to teach by example (apprenticeship). Confucius held that example was better than law (Jaspers, 1957, 47). For him, the best way to teach was by example. In his philosophy, junzi $i^{120}$, the superior man or the exemplary person was the exemplar of social value; and his behavior prompted emulation. If the ruler of a state was a good man, if he and his ministers lived in righteousness, then all the people would follow this good example and the state would enjoy harmony. More than that, if there was harmony and good order in one state, 
neighbouring states would want the same felicity and so civilization would spread even beyond the borders of China.

Study, for Confucius, means finding a good teacher and imitating his words and deeds. In his idea, when a person meets an evil man, he should examine himself to make sure he does not have the faults of the evil one; however, when a person meets a good man, he hopes to follow this example:

The Master said, "When we see men of worth, we should think of equaling them; when we see men of a contrary character, we should turn inwards and examine ourselves." (The Analects, Bk. IV, Ch. XVII.) 四: 十七 )

(子曰: “见贤思齐焉, 见不贤而内自省也。”《论语 里仁第

The Master said, "When I walk along with two others, they may serve me as my teachers. I will select their good qualities and follow them, their bad qualities and avoid them." (The Analects, Bk. VII, Ch. XXII.)

(子曰: “三人行, 必有我师焉。择其善者而从之, 其不善者 而改之。”《论语 述而第七・二十二》)

He also demonstrated how he himself learned by following exemplar.

The following is an example of Confucius' own learning experience:

When the Master was in company with a person who was singing, if he sang well, he [the Master] would make him [the singer] repeat the song, while he [the Master] accompanied it with his own voice. (The Analects, Bk. VII, Ch. XXXII.) 十二》)

(子与人歌而善, 必使反之, 而后和之。《论语 述而第七・ 三

The person who sings well serves as a model for others to imitate. For Confucius, learning from the good representative is the right way in studies.

In summary, the teaching methods of Confucius were flexible and diversified. He educated students according to their abilities. He taught new ideas by relating them to the familiar ideas and images. He did not pour the 
knowledge to his disciples; rather, he would cite passages from the classics and use heuristic teaching, making good use of the questions, the similes, the metaphors, the analogies, and the parables. Furthermore, he preferred teaching and learning by example.

In contrast, Socrates did not claim to be teaching, nor did he adopt various teaching methods. For this Greek philosopher, what he did, as he advocated, was educating or philosophizing. First, the places that Socrates met his students were informal. The city of Athens became the classroom of Socrates. He met students in private rooms, or in various public places, such as in the streets or in the market place. Participants could come and go as they pleased, respond or not respond to Socrates' probing questions.

Moreover, his conversation might be found perplexing or even ridiculous at first, although it was proved to be illuminating later. In Plato's Symposium, Alcibiades accounted for this extraordinary quality of Socratic talk:

I forgot to say at the beginning that his talk too is extremely like the Silenus-figures which take apart. Anyone who sets out to listen to Socrates talking will probably find his conversation utterly ridiculous at first; it is clothed in such curious words and phrases, the hide, so to speak, of a hectoring Satyr. He will talk of pack-asses and blacksmiths, cobblers and tanners, and appear to express the same ideas in the same language over and over again so that any inexperienced or foolish person is bound to laugh at his way of speaking. But if a man penetrates within and sees the content of Socrates' talk exposed, he will find that his talk is almost the talk of a god, and enshrines countless representations of ideal excellence and is of the widest possible application.

(221-222)

Socrates was known for confusing, and embarrassing his conversation partners into the unpleasant experience of realizing their own ignorance. Socrates himself did not have many teaching methods. He stuck to the main 
method (if not the only one), his dialectic questioning. He went about asking questions of authorities and of the man in the street in order to arrive at political and ethical truths. He was filled with an awareness of his vocation, of a divine mission, which was to "question unrelentingly, to expose every hiding place" (Jaspers, 1957, 6). He conversed with others about issues related to politics, pleasure and knowledge etc., questioned them and discovered the contradiction within their presumed conventions. He questioned groups of his students as a means of instruction, and forced them to think a problem through to a logical conclusion. Socrates professed his ignorance of the topic under discussion in order to elicit engaged dialogue with students. His dialectic method, or method of investigating problems through dialogue discussions, came to be known as the Socratic Method. This Socratic approach to teaching is based on the practice of such disciplined and strongly thoughtful dialogues.

The Socratic questioning had its own historical and social background. Around 4-5 B.C.E. conversation was the free Athenians' form of life. It also served as the instrument of Socratic philosophizing. In examining himself and others, conversations aroused, disturbed, compelled men's innermost souls. Jaspers $(1957,6)$ also pointed out the important role that free conversations played at that time: "Conversations and dialogues became necessary for the truth itself, which by the very nature opened up to an individual only in dialogue with another individual". In free talks, Socrates was particularly successful at drawing out people and revealing to them their particular internal contradictions or weaknesses.

In a famous analogy, Socrates compared his mission and his method to that of his mother, who was a midwife: 
But I have this feature in common with midwives-I myself am barren of wisdom. The criticism that's often made of me-that it's lack of wisdom that makes me ask questions, but say nothing positive myself-is perfectly true. Why do I behave like this? Because the god compels me to attend to the labours of others but prohibits me from having any offspring myself. I myself therefore am quite devoid of wisdom; my mind has never produced any idea that could be called clever. But as for those who associate with me-well, although at first some of them give the impression of being pretty stupid, yet later, as the association continues, all of those to whom the god vouchsafes it improve marvellously, as is evident to themselves as well as to others. And they make this progress, clearly, not because they ever learn anything from me; the many fine ideas and offspring they produce come from within themselves. But the god and I are responsible for the delivery.... When I ask a question, set about answering it to the best of your ability. And if, on examination, I find that some thought of yours is illusory and untrue, and if I then draw it out of you and discard it, don't rant and rave at me, as a first-time mother might if her baby were involved. ... I do what I do because it is my moral duty not to connive at falsehood and cover up truth. (Theaetetus, $150 \mathrm{c}-151 \mathrm{~b})$

For Socrates, he could only act as the midwife to truth. Therefore, he refused to be the transmitter of information that others were passively to receive, and he never accepted the comparison to teachers. Instead, he helped others recognize on their own what was real, true, and good. This was his own approach to education.

\section{On learning strategies}

Teaching and learning always go hand by hand. Socrates did not seem to make an effort in developing teaching methods, nor did he attach much importance to the learning strategies. If, there was one, his advice for the followers would be "self-examination". Socrates emphasized on examination and self-examination so as to avoid pretended self-knowledge or ignorance.

For Socrates, education was to "know thyself." The Delphic injunction "know yourself" was not addressed solely to Athens, but Socrates of Athens 
seemed to be the first to expect all people to adhere to it (also c.f. Kateb, 2009, 284). Socrates searched for wisdom and claimed never to find it. He was aware of his ignorance, unlike all those who let their practical expertise in a line of work inflated the estimate they made of their own wisdom about human things. Indeed, it was not clear that Socrates expected everyone to commit to the practice of self-examination. According to Kateb $(2009,284)$, it might be that he was alone or almost alone in subjecting himself to his own perpetual self-interrogation, to live by a silent internal dialogue about life. But he did suggest that if one could put up with being examined by someone else, especially a self-examining one like Socrates or some other (if there were others), then one could be disabused of pretended self-knowledge, because when ignorance about the most important issue is mistaken for wisdom, self-hurt and harm to others must follow.

In contrast, Confucian Analects contains many learning strategies. As a teacher, Confucius really cared about how his students should learn; hence, he gave earnest advice in this regard. If we sum them up, the suggested learning strategies cover (but do not limit to) the following aspects: the importance of love in learning, reviewing and reflection, and applying the knowledge in practice after it is gained-all these need great efforts and persistence.

\section{(1) Love of learning}

The Master said, "They who know the truth are not equal to those who love it, and they who love it are not equal to those who delight in it." (The Analects, Bk. VI, Ch. XX.)

(子曰: “知之者不如好之者, 好之者不如乐之者。” 《论语 雍 也第六・二十》) 
The Master said, "Learn as if you could not reach your object, and were always fearing also lest you should lose it." (The Analects, Bk. VIII, Ch. XVII.)

(子曰: “学如不及, 犹恐失之。”《论语 泰伯第八・十七》)

Confucius explained to Zi Lu that fondness in learning is close to wisdom because it can remove the six obstacles to and deficiencies in virtuous conduct:

The Master said, "You (Zi Lu), have you heard the six words to which are attached six becloudings?" You replied, "I have not." "Sit down, and I will tell them to you. There is the love of being benevolent without the love of learning - the beclouding here leads to a foolish simplicity. There is the love of knowing without the love of learning - the beclouding here leads to dissipation of mind. There is the love of being sincere without the love of learning - the beclouding here leads to an injurious disregard of consequences. There is the love of straightforwardness without the love of learning-the beclouding here leads to rudeness. There is the love of boldness without the love of learning - the beclouding here leads to insubordination. There is the love of firmness without the love of learning - the beclouding here leads to extravagant conduct." (The Analects, Bk. XVII, Ch. VIII.)

(子曰: “由也, 女闻六言六蔽矣乎？”对曰: “未也。”居！吾 语女。好仁不好学, 其蔽也愚; 好知不好学, 其蔽也荡; 好信不 好学, 其蔽也贼; 好直不好学, 其蔽也绞; 好勇不好学, 其蔽也 乱; 好刚不好学, 其蔽也狂。” 《论语 阳货第十七·八》)

In view of Zi Lu (a disciple of Confucius)'s courage in doing what was right, Confucius was disturbed that he might acted hastily and thus, opened the door to evil consequences and mistakes. So he enumerated the virtues of benevolence, wisdom, faithfulness, straightforwardness, courage and firmness, and explained that their cultivation depended on learning. Confucius explained, without learning, all other virtues were obscured as though by a fog and degenerate: without learning, frankness became vulgarity; bravery, disobedience; firmness, eccentricity; humanity, stupidity; wisdom, flightiness; sincerity, a plague. Important as virtuous nature is, one must constantly 
inquire and study to determine the rules of conduct. Only then can all things

be near to wisdom. This is why everyone should be fond of learning.

Confucius confessed that he himself never felt satiated with learning all his life. He decided to devote himself to learning at age 15:

The Master said, "At fifteen, I had my mind bent on learning. At thirty, I stood firm. At forty, I had no doubts. At fifty, I knew the decrees of Heaven. At sixty, my ear was an obedient organ for the reception of truth. At seventy, I could follow what my heart desired, without transgressing what was right." (The Analects, Bk. II, Ch. IV.)

(子曰: “吾十有五而志于学, 三十而立, 四十而不惑, 五十 而知天命, 六十而耳顺, 七十而从心所欲, 不逾矩。”《论语 为 政第二・四》)

Confucius was a very humble scholar, but when he spoke of the fondness for learning, he did not hesitate to say that in a village of ten families there might be a man as faithful and sincere as he was, but no one so fond of learning. His object here was to encourage among his students a fondness for learning:

The Master said, "In a hamlet of ten families, there may be found one faithful and sincere as I am, but not so fond of learning." (The Analects, Bk. V, Ch. X XVIII.)

(子曰: “十室之邑, 必有忠信如丘者焉, 不如丘之好学也。” 《论语 公冶长第五:二十八》)

In his old age, Confucius did not give up his learning efforts:

The Duke of She asked Zi Lu about Confucius, and Zi Lu did not answer him. The Master said, "Why did you not say to him, 'He is simply a man, who in his eager pursuit of knowledge forgets his food, who in the joy of its attainment forgets his sorrows, and who does not perceive that old age is coming on?" (The Analects, Bk. VII, Ch. X IX.)

(叶公问孔子于子路, 子路不对。子曰: “女奚不曰, 其为人 也, 发愤忘食, 乐以忘忧, 不知老之将至云尔。”《论语 述而第 七・十九》) 
Here, Confucius meant that learning is a lifelong pursuit. He became so fond of it himself that he was never tired of it. This development involved the above distinct stages: recognizing the importance of learning, acquiring a fondness for it and enjoying it. This expression about the passion for learning also correspond well with the Chinese culture's emphasis on learning assuming a central importance in one's life; therefore, one must be devoted to the accumulation of knowledge, and put his heart and mind wanting to learning.

\section{(2)Reviewing and reflection}

Confucius, who was fond of antiquity, sought diligently to obtain new judgments by studying old learning. Thus, he advised his students to acquire new knowledge from the study of the old:

The Master said, "If a man keeps cherishing his old knowledge, so as continually to be acquiring new, he may be a teacher of others." (The Analects, Bk. II, Ch. XI.)

(子曰: “温故而知新, 可以为师矣。”《论语 为政第二-十一》)

For Confucius, reviewing the knowledge learned and keeping the habits of reviewing and reflecting served as the path to new and true knowledge.

\section{(3)Practice}

Practice assumed such important position in Confucian education that it was placed before all other doctrines in the Analects:

The Master said, "To learn and unceasingly practice, does that not give satisfaction?" (The Analects, Bk. I, Ch. I.)

(子曰: “学而时习之, 不亦说乎?”《论语 学而第一一》) 
For Confucius, to learn with a constant perseverance and application is the right way in studies. He encouraged his students to practice the knowledge learnt, and moreover, to put all one learnt in helping administering the state-this might be the reason why he wanted his students to obtain offices in the government, and to apply his ideals in reality.

In the Analects, Confucius also discussed the relationship between thinking and learning in Analects. In his view, independent thought, springing from the nothingness of mere reason, was futile:

The Master said, "I have been the whole day without eating, and the whole night without sleeping; occupied with thinking. It was of no use. The better plan is to learn. " (The Analects, Bk. XV, Ch. XXXI.)

(子曰: “吾尝终日不食, 终夜不寝, 以思, 无益, 不如学也。” 《论语 卫灵公第十五: 三十一》)

One could not do without learning, or thinking. One demands the other-to learn without thinking is also vain:

The Master said, "Learning without thought is labour lost; thought without learning is perilous." (The Analects, Bk. II, Ch. $\mathrm{XV}$.)

(子曰: “学而不思则罔, 思而不学则殆。”《论语 为政第二. 十五》)

To summarize, apart from self-examination, Socrates did not advocate many learning strategies. In contrast, by "studying extensively, pondering thoroughly, sifting clearly, and practicing earnestly," Confucius carefully and systematically built up his learning framework.

\section{Source of knowledge}

In regarding the source of knowledge, Socrates held that knowledge or truth lay in the SELF. As analyzed in the previous sections, for Socrates, 
education was to "know thyself." Truth could not be prescribed by authority figures and was not socially negotiated, but was found within the self. This process demanded thought, questioning, testing so as to refer man to his own self. He emphasized individuals and valued self-generated knowledge. Knowledge was within the SELF. That was why Socrates emphasized on the dictum of 'know thyself', which includes self-knowledge and self-examination. It also explained why Socrates compared his mission of drawing out the truth within oneself to the midwife's art (c.f. Theaetetus). If one had trouble in finding out the right answer, Socrates would describe it as the "labour pains," and the whole process of finding truth within oneself was called 'delivery.' Theaetetus knew no answer and thought himself incapable of finding one. "You have labour pains," says Socrates, "because you are not empty but ready to bring forth." And Socrates went on to describe his way of speaking with the young men. Like a midwife he ascertained whether there was pregnancy or not; his methods enabled him to provoke pains and to appease them; he knew how to distinguish true birth from the birth of a vain shadow, a counterfeit. At first those who conversed with him simply seemed to become more ignorant, but only because they were freed from pseudo knowledge. Then "if the god is gracious to them, they all make astonishing progress ... yet it is quite clear that they never learned anything from me.... But to me and the god they owe their delivery." (Jaspers, 1957, 8) Truth is found within oneself, therefore, the more a man knows about himself, the greater his ability to reason out the correct choice and to choose those actions which truly bring happiness to him. For Socrates, no improvement was 
possible unless the individual was educated by educating himself, unless his hidden being was awakened to reality through an insight which was at the same time inner action.

For Confucius, the source of knowledge was from outside, or from OTHERS. Only through learning could one attain truth.

The Master said, "I have been the whole day without eating, and the whole night without sleeping; occupied with thinking. It was of no use. The better plan is to learn. " (The Analects, Bk. XV, Ch. XXXI.)

(子曰: “吾尝终日不食, 终夜不寝, 以思, 无益, 不如学也。” 《论语 卫灵公第十五: 三十一》)

The Master said, "When I walk along with two others, they may serve me as my teachers. I will select their good qualities and follow them, their bad qualities and avoid them." (The Analects, Bk. VII, Ch. XXII.)

(子曰: “三人行, 必有我师焉。择其善者而从之, 其不善者 而改之。”《论语 述而第七・二十二》)

The Master said, "If a man in the morning hears the right way, he may die in the evening without regret." (The Analects, Bk. IV, Ch. VIII.)

(朝闻道, 夕死可矣。《论语 里仁第四・八》)

When one regards the knowledge is from outside, there is the necessity to impart and transmit knowledge; and the way is to learn by following good examples instead of "giving birth" to knowledge by oneself.

\section{Preferred ways of learning}

For Socrates, asking and thinking may help one attain true knowledge. Socrates did not think that truth was easy to come by. In the Meno this is shown by a parable: a certain slave was confident at first that he knew the answer to a mathematical question; then he got into difficulties and recognized his ignorance, until at length, through further questions, he 
arrived at the correct solution. This example shows that truth comes to us in dialogue. Leading, questioning, giving information, and forcing his listeners to see the errors in their thinking-all these constitute the Socratic Method, a process of a continuous quest and an endless enquiry into oneself.

Socrates likened this activity of education to the midwife's art. At first those who conversed with him simply seemed to become more ignorant, but only because they were freed from pseudo knowledge. Then "if the god is gracious to them, they all make astonishing progress . . . yet it is quite clear that they never learned anything from me... But to me and the god they owe their delivery." (Jaspers, 1957, 8) This process demanded careful thought and questioning. Only the man who took such thinking seriously, not by vain thinking in words, but by the meaningful thinking that springs from the source, could arrive at the knowledge of the true and the good.

But for Confucius, learning is not through asking, but through listening and reading. If someone desires knowledge, he must listen in every quarter-man can get truth by hearing from others:

Hearing much and selecting what is good and following it; seeing much and keeping it in memory. (The Analects, Bk. VII, Ch. XXVIII.)

(多闻择其善者而从之, 多见而识之 《论语 述而第七・二 十八》)

The Master said, "If a man in the morning hears the right way/truth, he may die in the evening without regret/ die content." (The Analects, Bk. IV, Ch. VIII.)

(“朝闻道, 夕死可矣。”《论语 里仁第四・八》) 
Confucius described himself as "a transmitter and not a maker, believing in and loving ancient studies" ${ }^{121}$. This is the Confucian view of knowledge- knowledge begins with the empirical accumulation of masses of particulars. For Socrates, by contrast, knowledge was achieved through reasoning and the perception of eternal abstract forms, through a rigorous process of logic. While Socrates thought it essential to rise above the chaos of ordinary human experience, and only through questioning and thinking could one attain the true knowledge, Confucius did not attempt to rise from the chaos of the world of particulars to a world of eternal forms, since, in his view, the truth remains indissolubly linked to the empirical world and the right way to knowledge is to listen to and to read what is good.

\section{Attitudes towards the past}

Socrates challenged the past. Socrates relentlessly refused to accept answers untested in conversation and debate and refused to defer to opinions for which no reasoned account could be given. It did not matter whether those opinions were grounded in venerable tradition, poetic inspiration, or sincere personal convictions about one's own concept of existence. Socrates' standard was the truth about right and wrong.

In contrast, Confucius showed great admiration to the past. Confucius called himself a traditionalist and a lover of the old. He had an insatiable thirst for knowledge of the antiquity.

\footnotetext{
${ }^{121}$ The Analects, Bk. VII, Ch. I. The Master said, "A transmitter and not a maker, believing in and loving the ancients, I venture to compare myself with our old Peng.” (子曰: “述而不作，信而好古， 窃比于我老彭。” 《论语 述而第七・ 一》)
} 
The Master said, "Great indeed was $\mathrm{Yao}^{122}$ as a sovereign! How majestic was he! It is only Heaven that is grand, and only Yao corresponded to it. How vast was his virtue! The people could find no name for it. How majestic was he in the works which he accomplished! How glorious in the elegant regulations which he instituted!" (The Analects, Bk. VIII, Ch. XIX.)

(子曰: “大哉, 尧之为君也! 巍巍乎! 唯天为大, 唯尧则之。 荡荡乎! 民无能名焉。巍巍乎！其有成功也; 焕乎, 其有文章! ” 《论语 泰伯第八・十九》)

Confucian attitude had its own historical and cultural roots. At the very beginning of the Chinese history, it was said that there were three ideal figures who were the founders of society and government, manners and customs: Yao, Shun ${ }^{123}$, Yü ${ }^{124}$. They were regarded as the archetypes of good kings. Contemporary historians (c.f. Chen, 1990, 45; He \& Peng, 2009, 113; and Yao, 2000, 78 etc.) believe they may represent leader-chiefs of allied tribes who established a unified and hierarchical system of government in a transition period to the patriarchal feudal society. For these men Confucius had the highest praise: "Only heaven is great; only Yao was equal to it." The Record of Rites has a refined picture of the ideal society at that time. It was said that the state existed for the good of the people then. Virtuous and capable men were chosen as rulers, who cultivated sincerity of speech and kindliness in their relations with all. The people, in extending their loving devotion to their own families, were not forgetful of the interests of others. Maintenance was provided for the aged to the end of their lives, employment for the able-bodied, care for the young. Tender care was given to the widowed, the orphaned, the childless and the sick. The right of men to the work that suited them, and of women

\footnotetext{
122 尧, a legendary Chinese ruler, often extolled as a morally perfect and smart sage-king. 
to good homes, was recognised. Production was so regulated that nothing was wasted, while useless accumulations for private use were regarded with disapproval. Labour was so regulated that energy was stimulated while activity for merely selfish reasons was discouraged. Thus there was no room for the development of egoism. Robberies were unknown; hence there was no shutting of outer gates. Such was the age of the Great Commonwealth in the Confucian thought (Martin and Shui, 1972, 8).

Disappointment in the society in his own time was another reason that Confucius clung to the good old days. In the time of Yao, Shun and Yü, the great rulers chose the best of men as their successors. But evil was said to begin with the $\mathrm{Xia}^{125}$ dynasty when the principle of heredity set in. Inevitably the rulers declined in stature. In the end a tyrant, because he was not a ruler, was overthrown, by a revolution which once again appointed a true ruler, Tang ${ }^{126}$, founder of the Shang (Yin) ${ }^{127}$ dynasty. But since the throne remained hereditary, the same thing happened all over again. The last of the dynasty, again a ruthless tyrant, was overthrown in the twelfth century by the Zhou ${ }^{128}$ dynasty, which once more renewed the age-old Chinese world. But in Confucius' lifetime the new dynasty had become enfeebled in its turn and the Empire had crumbled into innumerable states. As what has been discussed in Chapter III, during the political and social chaos in the $5^{\text {th }}-6^{\text {th }}$ centuries B.C.E. China, life became difficult for the shi group from which Confucius himself arose. Their knowledge of aristocratic traditions, however, 
helped them remain valuable to competing kings, who wished to learn how to regain the unity imposed by the Zhou and who sought to emulate the Zhou by patterning court rituals and other institutions after those of the fallen dynasty. Confucius represented his teachings as knowledge transmitted from antiquity. He claimed that he was "a transmitter and not a maker" and that all he did reflected his "reliance on and love for the ancients."

The Master said, "A transmitter and not a maker, believing in and loving the ancients, I venture to compare myself with our old Peng ${ }^{129}$." (The Analects, Bk. VII, Ch. I.)

(子曰: “述而不作, 信而好古, 窃比于我老彭。”《论语 述 而第七: 一》)

The Master said, "I am not one who was born in the possession of knowledge; I am one who is fond of antiquity, and earnest in seeking it there." (The Analects, Bk. VII, Ch. XX.)

(子曰: “我非生而知之者, 好古, 敏以求之者也。”《论语 述 而第七: 二十》)

The Chinese people have traditionally taken a long-term perspective of life throughout history. They have emphasized tradition in order to secure a peaceful and reliable environment. For them, tradition is the measure of propriety to ensure that persons and things are in their proper places. In this view, Confucius sometimes idealized the good old times and borrowed the authority of the ancient ideal rulers in order to make his teaching more authoritative and effective. He might not have done that purposely, because there were enough traditional materials and popular beliefs for him to work out many of his own theories as having a basis in the teaching of the ancient ideal rulers, traditionally believed and recorded.

\footnotetext{
${ }^{129}$ There is a great deal of commentarial controversy concerning the meaning of the reference to "old Peng"- even if one or two people are being referred to. One possible explanation is that old Peng might be a great worthy of the Yin Dynasty who was fond of transmitting ancient tales by Bao Xian (Jiang 18). He was said to have been a historian and writer, noted for his profound scholarship.
} 
Kang Youwei ${ }^{130}$, the well-known Chinese politician and scholar in the early twentieth century, confirmed this idea in his work 'A Study of Confucius' Effort to Revolutionize the System of Chou by Attributing His System to the Ancient System". Chen Jingpan in his book Confucius as a Teacher (1990) also supports this point: "Indeed, in the long run, people would never believe in him [Confucius] so firmly if there were entirely no ground for him to attribute a certain part, at least, of his system to the ancient system" $(1990,192)$. Chen also observes that this way of borrowing the authority of ancient ideal rulers to illustrate one's own viewpoints was widely practised by the Chinese philosophers of the succeeding periods, such as Mo Zi ${ }^{131}$, Mencius (Mengzi ${ }^{132}$ ), and Xunzi ${ }^{133}(1990,192)$.

In addition to the praise and idealization of the past, Confucius also held a critical view about history. In his view, the way in which we assimilated the old did not bar our way, rather, it spurred us forward. In examining the past, Confucius distinguished between the good and the bad. He selected facts that were worth remembering as models to be emulated or examples to be avoided. Jaspers in his book The Great Philosophers (1957) claimed what Confucius advocated was not imitation of the past but repetition of the eternally true. The eternal ideas were merely more clearly discernible in antiquity. "Now, in his own dark times, he wished to restore them to their old radiance by fulfilling himself through them" (1957, 43-44). In doing this, he did not only carried on earlier traditions, but opened

\footnotetext{
130 康有为

131 墨子

132 孟子

133 荀子
} 
up new roads to knowledge. He organized and clarified the material he studied, developing his own theories from these sources. In examining Confucius' attitude towards the past, the present writer of the paper agrees with Jaspers' analysis, i.e. this way of looking at the old is in itself something new. Past realities are transformed by present reflection. The translation of tradition into conscious principles gives rise to a new philosophy which identifies itself with the old. Sometimes the philosophers do not advance their ideas as their own. The Jewish Prophets proclaimed God's revelation, Confucius the voice of antiquity. He who submits to the old is saved from the presumption of basing great demands on his own infinitesimal self. He improves his chances of being believed and followed by those who still live in the substance of their origins (c.f. Jaspers, 1957, 43). Confucius wished to work for a renewal. The philosophy of Confucius, the new one, expressed itself in the form of the old so that the source of eternal truth has become the substance of our existence.

\section{Attitudes towards customary notions and authorities}

As for the attitude toward the customary notions or conventions, still Socrates questioned them. In his apology to the jury, he confessed that he had propensity to question at the customary notions of gentlemanliness and education for gentlemanliness (Xenophon 27). He relentlessly refused to accept answers untested in conversation and debate. Kateb $(2009,284)$ even argues that Socrates has enriched the democratic battle against imposed definitions of the self by emphasizing self-examination $(2009,284)$. The Greek philosopher examined both himself and others, encouraging people to 
discover truth by themselves and to have their own individualistic judgment. He affirmed the primacy of reasonable judgment of what is right against any merely willful or arbitrary authority.

In contrast, Confucius emphasized on adherence to time-honored rituals and traditions, stressed conformity to customs and customary notions, showed respect and followed the great men and sages.

Confucius said, "There are three things of which the superior man stands in awe. He stands in awe of the ordinances of Heaven. He stands in awe of great men. He stands in awe of the words of sages. The mean man does not know the ordinances of Heaven, and consequently does not stand in awe of them. He is disrespectful to great men. He makes sport of the words of sages." (The Analects, Bk. XIV, Ch. VIII.)

(孔子曰: “君子有三畏: 畏天命, 畏大人, 畏圣人之言。小 人不知天命而不畏也, 狎大人, 侮圣人之言。”《论语 季氏第十 六・八》)

On one hand, Confucian respect of traditions and customary practice stemmed from his attitude towards the past, as discussed in the previous section; on the other hand, his loyalty and obedience to great men and sages also resulted from the social hierarchical structure of the ancient Chinese society. In that circumstance, Confucius thought loyalty and obedience were the right way for the good officials in serving the ruler, the common people to the authority, which was part of his very important concept, li.

Let the ruler be a ruler, minister be a minister, father be a father, son be a son. (The Analects, Bk. XII, Ch. XI.)

(君君, 臣臣, 父父, 子子.《论语 颜洲第十二.十一》)

If the relationship between young and old cannot be abandoned, how can the relationship between ruler and minister be abandoned? (The Analects, Bk. XVIII, Ch. VII.)

(长幼之节, 不可废也; 君臣之义, 如之何其废之? 《论语 微 子第十八・七》) 
To summarize, in this part we can see in the education process Socrates and Confucius shared similarities in the wide range of audience and the employment of diversified methods. However, great differences could be found in their conceptualization of the process. The Greek philosopher never claimed to teach, nor did he accept fees. In doing so, he was attending to his freedom. Socrates acted the midwife to truth. Confucius was quite the opposite: what he did was to teach and to transfer knowledge. He accepted tuition and set up a comprehensive and refined teaching system.

Confucius promoted such learning strategies as the love of learning, reviewing and practice, because in the Confucian view, knowledge began with the empirical accumulation of masses of particulars. By contrast, for Socrates, knowledge was achieved through reasoning and the perception of eternal abstract forms through a rigorous process of logic; therefore, "self-examination" was the only effective way to the real truth.

Questioning and thinking reflected the rationalistic trait of Socratic education, whereas for Confucius, the right way to knowledge was to listen to and to read what was good, as in his view the truth remained indissolubly linked to the empirical world.

In their attitudes towards the past and customary notions, Socrates refused to defer to opinions untested not matter whether they were grounded in venerable tradition, poetic inspiration, or any merely willful or arbitrary authorities. Socrates' standard was the truth about right and wrong. The Greek philosopher examined both himself and others, encouraging people to discover truth by themselves and have their own individualistic judgment. In contrast, Confucius idealized the good old times and borrowed the authority 
of the ancient ideal rulers in order to make his teaching more authoritative and effective. The different preferences marked with the distinct individualistic and collective trends were the result of the respective historical, social and cultural backgrounds of the two philosophers.

\section{The Nature of Education}

\section{SIMILARITIES:}

Both philosophers were dedicated in their pursuit of knowledge and believed that truth was available to humans. Socrates was not really a skeptic. He did think it necessary to shake people out of their commonplace presuppositions by questioning them and showing them that what they already believed did not stand up to criticism. But it was only the beginning of questioning - this setting the person free from what he previously took for granted without question. After that the person could seek the knowledge of virtue that Socrates thought was at least partly available to humans. Truth might be unknown to both participants in dialogue, but it was there. In the process of searching, he wished men to be confident of finding the truth. Both Socrates and the man he conversed with actually circled around it and were guided by it. Confucius had the same belief in the existence and availability of truth. Therefore, he advocated that through hearing and learning, could man obtain the true knowledge.

The Master said, "If a man in the morning hears the right way/truth, he may die in the evening without regret." (The Analects, Bk. IV, Ch. VIII.)

(“朝闻道, 夕死可矣。”《论语 里仁第四・八》) 
Hence both Socrates and Confucius had the confidence in the existence of truth and had the trust that men can finally arrive at the truth. Thus, their questioning, disproving, and studying process were sustained by the confidence that the truth would disclose itself if one persevered, and that through a candid awareness of what one did not know, one would arrive not at nothingness but at the knowledge that is crucial for life.

\section{DIFFERENCES:}

\section{What they were doing: to philosophize vs. to instruct}

As what has been discussed in the previous section, what Socrates did was not teaching. For Socrates, his task was to educate, or to 'philosophize'. In Plato's Apology of Socrates, the philosopher argued, "I shall obey the God rather than you, and while I have life and strength I shall never cease from the practice of philosophy, exhorting anyone whom I meet and saying to him after my manner: You, my friend ... are you not ashamed ... to care so little about wisdom and truth and the greatest improvement of the soul, which you never regard or heed at all?" (82) He stressed the distinctiveness of individuals, and argued that knowledge should not be accepted without question from 'authoritative' sources; rather, each person had to find their own truth within themselves. For him, this was the genuine education. Truth was not prescribed by authority figures and was not socially negotiated, but was found within the self.

The modern German philosopher, Karl Jaspers, also noted in his account of Socrates that what the philosopher meant by education was not some casual operation that the knower performed on the unknowing, but the 
element in which men, communicating with each other, came to themselves, in which the truth opened up to them $(1957,6)$. To achieve clarity Socrates needed men, and he was convinced that they needed him: above all, the young men. The young men helped him when he wanted to help them. Socrates "taught them to discover the difficulties in the seemingly self-evident; he confused them, forced them to think, to search, to inquire over and over again, and not to sidestep the answer, and this they could bear because they were convinced that truth is what joins men together" (Jaspers, 1957, 6). For Socrates, the purpose of education was to find truth within oneself. Socrates did not hand down wisdom but made the other find it. The other thought he knew, but Socrates made him aware of his ignorance, so leading him to find authentic knowledge in himself. From miraculous depths this man raised up what he already knew, but without knowing that he had known it. This meant that each man must find knowledge in himself. Knowledge was not a commodity that could be passed from hand to hand, but could only be awakened. When it came to light, it was like a recollection of something known long ago. And that was why, Socrates claimed that in the pursuit of philosophy, he could search without knowing. A Sophist had said: I can search only for what I know; if I know it, I no longer have to search for it; if I do not know it, I cannot search for it. In the Socratic view, however, to philosophize was to search for what men already knew. But they knew it unconsciously, as though in a dim, ancient memory, and now they wished to know it in the bright light of their present consciousness (Jaspers, 1957, 8). 
In contrast, what Confucius did was to teach, or to 'instruct'. The Chinese

philosopher was engaged in transmitting the cultural heritage.

The Master said, "From the man bringing his bundle of dried flesh for my teaching upwards, I have never refused instruction to anyone." (The Analects, Bk. VII, Ch. VII.)

(自行束修以上, 吾未尝无诲焉。《论语 述而第七·七》)

The Master said, "The sage and the man of perfect virtue-how dare I rank myself with them? It may simply be said of me, that I strive to become such without satiety, and teach others without weariness." (The Analects, Bk. VII, Ch. XXXIV.)

(抑为之不厌, 诲人不倦, 则可谓云尔已矣。《论语 述而第 七· 三十四》)

The Master said, "The silent treasuring up of knowledge; learning without satiety; and instructing others without being wearied - which one of these things belongs to me?" ${ }^{134}$ (The Analects, Bk. VII, Ch. II.)

(默而识之, 学而不厌, 海人不倦, 何有于我哉? 《论语 述 而第七·二》）

The Master said, "In teaching there should be no distinction of classes." (The Analects, Bk. XV, Ch. XXXIX.)

(有教无类《论语 卫灵公第十五: 三十九》)

Yan Yuan ${ }^{135}$, in admiration of the Master's doctrines, sighed and said, "...The Master, by orderly method, skillfully leads men on. He enlarged my mind with learning, and taught me the restraints of propriety..." (The Analects, Bk. IX, Ch. XI.)

(颜渊喟然叹曰: “...... 夫子循循然善诱人, 博我以文, 约我 以礼.......《论语 子罕第九・十一》)

While Socrates concerned himself with how to construct knowledge,

Confucius was devoted in transmitting knowledge. In the Analects, Confucius identified himself as "a transmitter and not a maker." 136 In practice, he taught his students morality, proper speech, government, and the refined arts. He

\footnotetext{
${ }^{134}$ Confucius was a very humble teacher in saying so.

${ }^{135}$ As mentioned earlier, Yan Yuan (颜波) was one of the favourite disciples of Confucius.

${ }^{136}$ The Analects, Bk. VII, Ch. I. The Master said, "A transmitter and not a maker, believing in and loving the ancients, I venture to compare myself with our old Peng.” (子曰: “述而不作，信而好古， 窃比于我老彭。”《论语 述而第七·一》)
} 
emphasized the "Six Arts" (liuyi $\left.{ }^{137}\right)$, which included ritual $\left(l i^{138}\right)$, music $\left(y u e^{139}\right)$, archery $\left(s h e^{140}\right)$, chariot-riding $\left(y u^{141}\right)$, calligraphy $\left(s h u^{142}\right)$, and computation $\left(s h u^{143}\right)$. Above all, it is clear that Confucius regards morality the most important subject in teaching his students. For him, the practice of right living is the highest of all arts. He believed what he was doing was transmitting the Way $\left(\mathrm{Dao}^{144}\right)$ of the sages of Zhou antiquity.

\section{Rationality vs. faith}

Socrates attempted to establish an ethical system based upon human reason rather than upon theological directives. He believed in the primacy of knowledge and the importance of definitions. For Socrates, finding out truth was an intellectual activity through his procedure of question and answer which has come to be known as the 'elenchus'. The purpose of the dialogue was to clarify people's ideas, or to 'rid their minds of error', as he called it. He believed that too many people accepted ideas at second-hand without ever questioning them. Once they had acquired them, they applied them automatically, without any real understanding of them, and in some cases gained an unjustified reputation for wisdom. Socrates, on the other hand, said that he himself was the wisest man in the world because he did not pretend to know what he did not know. His wisdom consisted of recognizing his own

\footnotetext{
137 六艺, also known as the "Six Classics". They were they were single out by Chinese scholars as the "Six Arts" in the Rituals of Zhou (Zhou Li, 周礼) in the Han dynasty (202B.C.E.-220 C.E.).

138 礼

139 乐

140 射

141 御

142 书

143 数

144 道
} 
limitations and his ability in reasoning. Socrates also attached importance on the skills in thinking. In his idea, each man must develop his skill in critically appraising propositions through the reasoning process. Since man's self resides solely in the knowledge of the true and the good, only the man who takes such thinking seriously, who is determined to be guided by the truth, is truly himself. By asking questions, a critical thinking strategy, he attempted to rid his own mind and the minds of other people of preconceived ideas, which were often a barrier to understanding.

In this perspective, Confucius is quite different from Socrates, who demanded no faith in anything or in himself, but to demand thought, questioning, testing, and so refer man to his own self. First, Confucius claimed that he enjoyed a special and privileged relationship with Heaven $\left(\operatorname{tian}^{145}\right)$. He argued that by the age of fifty, he had come to understand what Heaven had mandated for him and for mankind.

Confucius said, "There are three things of which the superior man stands in awe. He stands in awe of the ordinances of Heaven. He stands in awe of great men. He stands in awe of the words of sages. The mean man does not know the ordinances of Heaven, and consequently does not stand in awe of them. He is disrespectful to great men. He makes sport of the words of sages." (The Analects, Bk. XIV, Ch. VIII.)

(孔子曰: “君子有三畏: 畏天命, 畏大人, 畏圣人之言。小 人不知天命而不畏也, 狎大人, 侮圣人之言。”《论语 季氏第十 六・八》)

The Master said, "At fifteen, I had my mind bent on learning. At thirty, I stood firm. At forty, I had no doubts. At fifty, I knew the decrees of Heaven. At sixty, my ear was an obedient organ for the reception of truth. At seventy, I could follow what my heart desired, without transgressing what was right. " (The Analects, Bk. II, Ch. IV.) 
(子曰: “吾十有五而志于学, 三十而立, 四十而不惑, 五十 而知天命, 六十而耳顺, 七十而从心所欲, 不逾矩。”《论语 为 政第二·四》)

Confucius not only stood in awe of the ordinances of Heaven, he was also careful to instruct his followers that they should never neglect the offerings due Heaven.

Wang Sun Jia asked, saying, "What is the meaning of the saying, 'It is better to pay court to the furnace than to the southwest corner?"' The Master said, "Not so. He who offends against Heaven has none to whom he can pray. " (The Analects, Bk. III, Ch. IIIX.)

(王孙贾问曰: “与其媚于奥, 宁媚于䆹，何谓也？”子曰: “不 然，获罪于天，无所祷也。”《论语 八佾第三・十三》)

Richey argues in his online Encyclopedia of Philosophy that the dependence of Tian (Heaven) upon human agents to put its will into practice helps account for Confucius' insistence on moral, political, social, and even religious activism. This claim has some reason in itself. In the history, Zhou apologists regarded their deity, $\operatorname{Tian}^{146}$ (Heaven), as the deity of the deposed Shang kings, and described the decline of Shang and the rise of Zhou as the consequence of a change in Tianming ${ }^{147}$ ("the ordinances of Heaven"). Thus, theistic justifications for conquest and ruler-ship could be observed very early in Chinese history. In the time of Confucius, the concept of Tian changed slightly. For one thing, the ritual complex of Zhou diviners, which served to assert the will of Tian for the benefit of the king, had collapsed with Zhou dynasty itself. At the same time, the network of religious obligations to manifold divinities, local spirits, and ancestors did not seem to cease with the fall of the 
Zhou rule. In this circumstance, Confucius maintained and supported sacrifices to "gods and ghosts" as he argued to transmit the noble tradition.

While Socrates questioned the definition of virtue, Confucius had belief in the learning of virtues, and he used an intuitive approach when he tried to get his students to see and recognize the value of the truths. For Confucius, the fundamental moral truths were directly apprehended as true by a special faculty of moral knowledge-he prized moral inclination rather than cause-effect deliberation. His belief in the "contagious" nature of moral force $\left(\mathrm{de}^{148}\right)$ led to his favourite way of teaching, which was by example. Junzi ${ }^{149}$ (the exemplary person) was the very model for emulation: as a moral parent would raise a moral child, a moral ruler or an exemplary model would diffuse morality to those under his sway. These approaches are primarily ethical, rather than analytical-logical or metaphysical in nature. No wonder in this sense Richey remarked that "there is no or very little analytical-logical tradition in China." 150 It may sound a bit extreme, but it reflects the intuitive trend in the Chinese traditional culture.

Furthermore, Confucius preferred poems and poetic devices in his instruction. He believed that the most important lessons for obtaining such moral education were to be found in the canonical Book of Poetry, in which many of its poems were both beautiful and good. Thus Confucius placed the text first in his curriculum and frequently quoted and explained its lines of verse. For this reason, the Analects is also an important source for Confucius'

\footnotetext{
148 德

149 君子

${ }^{150}$ Quoted from the Online Encyclopaedia of Philosophy. Refer to the website: www.iep.utm.edu/confuciu/
} 
understanding of the role poetry and art play in the moral education of

gentlemen as well as in the reformation of society.

The Master said, "My children, why do you not study the Book of Poetry? The Odes serve to stimulate the mind. They may be used for purposes of self-contemplation. They teach the art of sociability. They show how to regulate feelings of resentment. From them you learn the more immediate duty of serving one's father, and the remoter one of serving one's prince. From them we become largely acquainted with the names of birds, beasts, and plants." (The Analects, Bk. XVII, Ch. IX.)

(子曰: “小子! 何莫学夫诗? 诗, 可以兴, 可以观, 可以群, 可以怨。迩之事父, 远之事君。多识于鸟兽草木之名。”《论语阳 货第十七·九》)

The Master said, "In the Book of Poetry are three hundred pieces, but the design of them all may be embraced in one sentence-'Having no depraved thoughts."' (The Analects, Bk. II, Ch. II.)

(子曰: “诗三百, 一言以蔽之, 曰'思无邪”。”《论语 为政 第二:二》)

Zi Gong ${ }^{151}$ said, "What do you pronounce concerning the poor man who yet does not flatter, and the rich man who is not proud?" The Master replied, "They will do; but they are not equal to him, who, though poor, is yet cheerful, and to him, who, though rich, loves the rules of propriety." $\mathrm{Zi}$ Gong replied, "It is said in the Book of Poetry, 'As you cut and then file, as you carve and then polish ${ }^{152}$.' - The meaning is the same, I apprehend, as that which you have just expressed." The Master said, "With one like Ci (Zi Gong), I can begin to talk about the odes. I told him one point, and he knew its proper sequence. " (The Analects, Bk. I, Ch. XV.)

(子贡曰: “贫而无谄，富而无骄，何如？”子曰: “可也。未 若贫而乐, 富而好礼者也。”子贡曰: “《诗》云: '如切如磋, 如 琢如磨。'其斯之谓与? ”子曰: “赐也, 始可与言诗已矣！告诸往 而知来者。”《论语 学而第一 十五》)

$\mathrm{Zi} \mathrm{Xia}{ }^{153}$ asked, saying, "What is the meaning of the passage - 'The pretty dimples of her artful smile! The well-defined black and white of her eye! The plain ground for the colours?' " The Master said, "The business of laying on the colours follows (the preparation of) the plain ground."

"Ceremonies then are a subsequent thing?" The Master said, "It is Shang (Zi Xia) who can bring out my meaning. Now I can

151 子贡, a student of Confucius.

${ }^{152}$ Like "cutting and grinding" stones, one can constantly improve and refine himself.

153 子夏, a student of Confucius. 
begin to talk about the odes with him. " (The Analects, Bk. III, Ch. VIII.)

(子夏问曰: “巧笑倩兮, 美目盼兮, 素以为绚兮。'何谓也？” 子曰: “绘事后素。”曰: “礼后乎? ”子曰: “起予者商也! 始可与言 诗已矣。” 《论语 八佮第三・八》)

Recent archaeological discoveries in China of previously lost ancient manuscripts have revealed other aspects of Confucius' reverence for the Book of Poetry and its importance in moral education. These manuscripts show that Confucius had found in the canonical text valuable lessons on how to cultivate moral qualities in oneself as well as how to comport oneself humanely and responsibly in public. Of course, lines in these poems are known for their vagueness and allow multiple interpretations.

Besides odes and poems, Confucius also regarded music and manners fundamental. In his idea, a man is awakened by the Odes (the Book of Poetry, Shijing $\left.{ }^{154}\right)$, strengthened by the li, perfected by music.

The Master said, "It is by the Odes that the mind is aroused. It is by the Rules of Propriety that the character is established. It is from Music that the finish is received." (The Analects, Bk. VIII, Ch. VIII.)

(子曰: “兴于诗, 立于礼。成于乐。” 《论语 泰伯第八-八》)

In his view, the appropriate use of a quotation from the Book of Poetry (Shijing), the perfect execution of guest-host etiquette, and the correct performance of court ritual all serve a common end: they regulate and maintain order. Unlike Socrates, the rational fighter against conventions, Confucius seemed more like an erudite guardian of tradition who instructed his disciples to emulate the sages of the past in order to restore the moral integrity of the state. 


\section{Free will vs. commitment}

Socrates valued free spirit. He did not limit his teaching to a select coterie; rather, he conversed with people in the streets and market place, in full public view. In doing so, he did not charge anything for tuition fee. According to Xenophon's Memorabilia, in refraining from charging money, Socrates was attending to his freedom: "If we want to find out the underlying reason, it was because of the precious freedom that Socrates pursued all his life." In his final defence, the philosopher himself sighed: "And do you know any human being who is more free than I-who accept from no one either gifts or wages?" $(1994,13)$ Moreover, he called those who took pay for their association enslavers of themselves, because of its being necessary that they conversed with those from whom they took their pay $(1994,14)$.

In Plato's Apology of Socrates, the philosopher confessed: "But neither did I then suppose that I should do anything unsuitable to a free man because of the danger, nor do I now regret that I made my defense speech like this: I much prefer to die having made my defense speech in this way than to live in that way." $(1979,93)$ Although there is hardly any surviving Greek literature that contains formal articulation of the modern concept of individual uniqueness, Kateb indicates that intimations can certainly be found in the Stoic doctrine of inner freedom, according to which "the self can rise above slavish passivity by correct interpretation or mental rearrangement of experience"(2009, 277). Socrates stressed the inner freedom and distinctiveness of individuals. He argued that knowledge should not be accepted without questioning from 'authoritative' sources; rather, each person 
had to find their own truth within themselves. For Socrates, this was the genuine education. Only when one got to know his own ignorance, and therefore was freed from the pseudo knowledge, could he truly embark on the journey of thought.

Quite different from Socrates, the pursuit of individual freedom was not the goal for Confucius, who attached great importance on social responsibility and commitment. Unlike the Socratic view, education for Confucius focused more on social rather than individual dimensions. In a sense, much of his teaching is directed toward the maintenance of the social and moral order. As for the human person, Confucius called for a lifelong pursuit of love or humanheartedness (ren), a personal cultivation that involves achieving inner equanimity and outer integrity and responsibility to society.

As for the whole society, the virtues of loyalty (zhong) and rules of proper conduct (li) led ultimately to harmony and order, which were Confucius' goals. In the Analects, there are numerous related passages, among which are:

"...the art of governing is to keep its affairs before the mind without weariness, and to practice them with undeviating consistency." (The Analects, Bk. XII, Ch. XIV.)

(“......居之无倦, 行之以忠。”《论语 颜渊第十二.十四》)

The duke Ding asked how a prince should employ his ministers, and how ministers should serve their prince. Confucius replied, "A prince should employ his minister according to the rules of propriety; ministers should serve their prince with faithfulness." (The Analects, Bk. III, Ch. XIX.)

(定公问: “君使臣, 臣事君, 如之何? ”孔子对曰: “君使臣 以礼, 臣事君以忠。”《论语 八佾第三・十九》)

The Master said, "A youth, when at home, should be filial, and, abroad, respectful to his elders. He should be earnest and truthful. He should overflow in love to all, and cultivate the friendship of the good. When he has time and opportunity, after the performance of these things, he should employ them in polite studies." (The Analects, Bk. I, Ch. IV.) 
(子曰: “弟子入则孝, 出则弟, 谨而信, 泛爱众, 而亲仁。 行有馀力, 则以学文。” 《论语 学而第一: 六》)

The Chinese philosopher Confucius found himself in an age in which values were out of joint. "Rulers do not rule and subjects do not serve," as he observed (The Analects, Bk. XII, Ch. $\mathrm{XI}^{155}$ ). Moral education was important to Confucius because it was the means by which one could rectify this situation and restore values and orders to society. In his view, the solution was to build up the proper relationship in the family and in the country. One must deal well with the relationship with one's parents and others around him. Only after these things were taken care of, was it proper to go off and employ oneself in other things. His philosophy consisted of a sense of order, commitment in vertical and horizontal relations and obligations, and the responsibility for government and society, with an aim for harmony and cooperation in the group. This philosophy has great impact on the forming of the essential philosophical and cultural basis in Chinese society.

\section{Destructor vs. constructor}

In his life, Socrates was known for confusing, stinging and stunning his conversation partners into the unpleasant experience. For those who conversed with him, the unpleasant experience of realizing their own ignorance sometimes might take place of their genuine intellectual curiosity. Here is an example in Plato's dialogue. While discussing virtue (arete) with Socrates, Meno was driven into a corner by Socrates' questions. "Even before

\footnotetext{
${ }^{155}$ Duke Jing of Qi asked Confucius about government. Confucius replied: "Let the ruler be a ruler, minister be a minister, father be a father, son be a son.” (The Analects, Bk. XII, Ch. XI.) (齐景公问政于孔子。孔子对曰: “君君，臣臣，父父，子子。”《论语 颜渊第十二·十一》)
} 
I met you," said Meno, "they told me that in plain truth you are a perplexed man yourself and reduce others to perplexity. At this moment I feel you are exerting magic and witchcraft upon me and positively laying me under your spell until I am just a mass of helplessness. If I may be flippant... you are exactly like the flat sting ray that one meets in the sea. Whenever anyone comes into contact with it, it numbs him..." (Jaspers, 1957, 7-8). Socrates did not develop any systematic knowledge; instead, he acted as the 'flat sting ray' or the 'gadfly' of the state. Even in the trial of the Greek philosopher, his defense turned into an attack on the judges. "For if you kill me," Socrates declared, "you will not easily find another like me, who, if I may use such a ludicrous figure of speech, am a sort of gadfly, given to the city by God . . . always fastening upon you, arousing and persuading and reproaching you. ... [But] you may feel out of temper like a person suddenly awakened from sleep and might suddenly strike me dead . . . and then sleep on for the remainder of your lives." $(1957,112)$.

Socratic individualism consists in taking oneself seriously as an object of existential and moral inquiry. In fact, the Socratic Method is a negative method of hypothesis elimination, in which better hypotheses can only be found by steadily identifying and eliminating those which lead to contradictions. It was designed to force one to examine one's own beliefs and the validity of such beliefs. Although what Socrates strove to do was to actualize the substance of thought itself and awaken it to inner action within people he conversed with, yet the experience of being stung could not fully understood and appreciated by everyone in the ancient Greece. Alcibiades confessed that it was Socrates who compelled him to realise that 
he was still a mass of imperfections and yet persistently neglected his own true interests by engaging in public life. "So against my real inclination I stop up my ears and take refuge in flight, as Odysseus did from the Sirens" (216a). In the similar state of mind Theaetetus said that he felt dizzy; and Socrates induced him into a feeling of shame (Sowerby, 2009, 149). Sometimes the feeling of pain went even beyond the feeling of shame. People soon found that once they began to ask questions they were frequently forced to abandon many preconceptions, often those which they held most dear. By asking questions and examining himself and others, Socrates poised a big challenge to the most authoritative opinions, and attacked on their paternal and political authority. He attacked people's most deeply cherished convictions about the meaning and conduct of human life, the beliefs on which the family and the city depended which constituted their very reason for being. He striped people's belief without giving them anything in replace.

Furthermore, in doing Greek youth the good of education, Socrates did not make them more loyal and effective rulers or citizens or family members. Instead, the youth followed and imitated him, and they made their elders look foolish by showing up their ignorance. Therefore, the philosopher did not benefit the people in Athens in the eyes of the city or with a view to the common good. Many people hated him. In the end, Socrates was accused and judged, and finally sentenced to death. He died by drinking poison hemlock. In contrast, Confucius was more like a constructor. First, the teaching process of Confucius is positive. Confucius made education available to students from all classes. He organized and clarified the material he studied, developing his own theories from these sources. In teaching, he knew his 
students and employed different teaching methods, including heuristic teaching and teaching by example. He also made good use of poems, parables and various rhetorical devices in the teaching process. Confucius devoted himself in knowledge transmission and systematically built up a complete ethical and learning framework. This great educator not only carried on earlier traditions, but opened up new roads to knowledge.

Apart from education, Confucius also acted in a positive way in social life. In his life, Confucius safeguarded the paternal social system, and reinforced convictions and customary notions. In the Analects, Confucius was a guardian of tradition who challenged his disciples to emulate the sages of the past and to restore the moral integrity of the state. The main idea of Confucius was to administer the country with morals. The ethics of Confucius not only informed the traditional curriculum, they were also a powerful mechanism for implementing the ethical and social norms of Chinese society. In discussing the emperor-minister relationship, Confucius argued the importance of the rules of propriety and loyalty. Regarding personal relationships he advocated virtues of benevolence and trustworthiness. Within family, he thought benignity and filial piety were the rules. Such moral forces helped to realize Confucius' vision of an ideal society: a well-ordered family, a well-ordered state, and a well-ordered world. Men actively shape their life together and, transcending all instinct, build it on their human obligation.

In Confucian sayings and dialogues, prohibitions were far less frequent than advice instructing the young people how to get on the world. Confucius taught them how to be good family members, how to be faithful citizens, loyal officials, or effective rulers. All these met the requirements of 
political and social life at that time. Such teachings of Confucius consolidated the social system. His values and behaviours helped to achieve the goal of promoting social harmony; and under his influence, the conforming behaviour is encouraged over exploration and deviation from the established norms.

To summarize, as for the nature of education, both philosophers believed in the availability of truth, but they differed in their views about ways to truth. Socrates held knowledge could only be awakened by rational inquiry, while Confucius preferred to transmit and impart knowledge. Rational trait was distinct when Socrates chose to employ human reason rather than theological directives. In contrast, Confucius preferred to resort to "the decrees of Heaven"; odes, poetry and music lent more intuitive characteristics to the Confucian teaching. In education, Socrates chose the more individualistic way by stressing the inner freedom and distinctiveness of individuals, whereas Confucius showed more collective trend by attaching great importance on social responsibility and commitment.

\section{E. Summary}

In this chapter similarities and differences have been found in Socratic and Confucian education philosophy respectively in the aim of education, the content of education, the teaching process and the nature of education.

First, the goals of education for both Socrates and Confucius were to help themselves and others in self-improvement. For Socrates, the purpose of education was to find truth within oneself. Due to special historical contexts 
and personal reasons, Confucius aimed more on helping his students become future statesmen and thus realizing his own political ideals. He hoped that by cultivating ideal ways of life and full development of the personality, rulers could bring about an ideal social order and put things right from chaos. Compared with the individualist views of Socrates, such aims of Confucius had more social dimension, which were also inherent in the content, style and nature of education.

In the content of education, both Socrates and Confucius showed great interest in moral truth, or the practice of right living and they had long discussions on ethics and virtues. Both of them embodied the virtues they advocated. They shared similar views in some virtues such as frugality and self-knowledge. While Socrates showed more concern on the individual's need and the health of one's own soul, the Chinese philosopher Confucius showed more interest in concepts like loyalty, filial piety, and rules of proper conduct, which were absent in the Socratic conversations. Confucius called for a personal cultivation that involved achieving inner equanimity and outer integrity and responsibility to society. He led more efforts in the studies on the inter-personal relationships which helped to give order and harmony to the society.

In the process of education, both of them shared similar views on the wide selection of their students/audiences-in their practice, education was opened up to almost everyone; and both educators possessed the capacity to speak differently to different audiences. The Greek philosopher differed himself from the sophists who were interested in giving their pupils techniques of speaking and refused to take money for what he did in the pursuit of 
freedom; while as a real teacher, Confucius accepted the tuition fee, and built up a comprehensive and refined teaching system. He selected and edited ancient texts as his teaching materials. He knew his students very well, and his teaching methods were flexible and diversified. In effectively using similes, metaphors, analogies, and parables, Confucius connected new and abstract ideas with the familiar and known images. Confucius also argued the importance of learning by following exemplar, and put forward many effective learning strategies such as the love of learning, reviewing and reflection and applying the knowledge in practice. In comparison, Socrates did not claim to be teaching, nor did he adopt various teaching methods. For this Greek philosopher, what he did, as he advocated, was philosophizing. His main method, if there was one, was his dialectic questioning, which was to help, or even force people to discover the contradiction within their presumed conventions. He was referred to as the midwife to truth. In addition, as for the source of knowledge, Socrates held that knowledge or truth lay in the SELF, while Confucius maintained that one could only learn knowledge from OTHERS, or from outside. The preferred ways of learning for Socrates were to ask and think, because for him knowledge was achieved through reasoning and the perception of eternal abstract forms, through a rigorous process of logic. But for Confucius, knowledge began with the empirical accumulation of masses of particulars, so he preferred to learn through listening and reading what is good. Due to different cultural backgrounds, the two philosophers also differed in their attitudes towards the past, customs and authorities: Socrates relentlessly questioned customary notions and encouraged people to have their own individualistic judgment. In contrast, 
Confucius showed great admiration to the past, stressed conformity to the time-honored rituals and traditions and the importance of following the great men and sages.

Both philosophers were devoted in their pursuit of knowledge and had belief in the existence and availability of truth. But they differed in their views in the nature of education. For Socrates, to educate means to "philosophize", to help people know themselves; yet in Confucian view the same concept refers to teach, or to 'instruct', or to transmit and impart knowledge. Socrates believed in rationality and attempted to establish the ethical system based upon human reason and placed importance on the primacy of knowledge. In contrast, Confucius claimed faith in Heaven and relied on an intuitive approach in recognizing the value of the truths. His belief in the "contagious" nature of moral force $\left(d e^{156}\right)$ led to his favourite way of teaching, which was by example. Unlike Socrates, who fought against conventions in safeguarding his own free will, Confucius seemed more like an erudite guardian of tradition instructing his disciples to emulate the sages of the past with strong sense of social responsibility and commitment. While Socrates employed a negative method of hypothesis elimination, and striped people's belief in his inquiries, the teaching process of Confucius was positive, which brought about order and harmony to the society and helped to consolidate the political system.

As analysed above, it could be found that the epistemological differences of the two philosophers were interwoven with their respective cultural values. Individualistic and rationalist traits were embedded in Socrates' education, while Confucius' teaching was distinctively marked with collective and intuitive 
characteristics. Their thoughts were the products of their own culture, and at the same time, the thoughts of philosophers also left great impacts on the development of each culture. 


\section{CHAPTER V. THE IMPLICATIONS}

Both Socrates and Confucius have left immeasurable impacts on the cultures in the West and East. They greatly influenced their disciples and followers. Moreover, the Socratic and Confucian philosophy of education also deeply impacts the Western and Chinese teaching and learning practice.

\section{A. Influence on Their Disciples}

\section{Socratic Impacts}

Socrates has been regarded as the embodiment of the spirit of his age (Richmond, 1954, 7). The fact that our knowledge of him is fragmentary and second-hand in no way lessens his significance. He has a lasting impact in Greek philosophy-a movement that last until today.

\section{Plato}

Among the group of followers of Socrates, including Apollodorus, Aristodemus, and Xenophon etc., Plato was better placed than others to understand Socrates' teaching. Although Plato earlier showed an interest in politics, Socrates' death sentence and disillusionment with the behaviour of the oligarchy of the Thirty Tyrants that assumed power in 404 B.C.E. seemed to have caused Plato to turn to a life of philosophical reflection and writing. Almost all of Plato's writings dated from after Socrates' trial and execution. 
As one of the favourite students of Socrates, Plato, whose lifetime was prolonged for over fifty years after Socrates' execution, transmitted the main stream of Socratic thoughts. In his Apology of Socrates, Plato made it clear that he was a devoted young follower of Socrates. His reverence for Socrates served as the inspiration and starting-point of his own reflections. Plato was passionately concerned with the questions which also had once excited Socrates-whether law and morals were natural or conventional in origin, whether 'virtue' could be taught, whether intelligence or inanimate nature was prior, whether all values were relative, the nature and standing of rhetoric, the relation between being and seeming, knowledge and opinion, language and its objects, etc. Like Socrates, Plato argued that people are born with innate patterns of thought, and that we are born with all the knowledge that we will ever have. "That is, knowledge is present in the human mind at birth. It is not so much that we 'learn' things in our daily experiences, but we 'recollect' them" (West and West, 1998, 56). For Plato, learning is the process of recollection; and we just bringing into full consciousness of knowledge that was latent in the mind already (Guthrie, 1971, 17). Plato also showed how a pretense of wisdom, even if only about one's proposed course of study or action, can lead to unjust, impious deeds, in the example of Euthyphro and Meletus (Scott, $2000,39)$.

Plato's writings have been generally divided into three broad groups: the "Socratic" dialogues (written from 399 to 387), the "Middle" dialogues (written from 387 to 361, after the establishment of his Academy in Athens), and the "Later" dialogues (written in the period between 361 and his death in 347) (Cooper, 2005, 970; and Curren, 2007, 8). Other than Aristophanes, the comic 
playwright, or Xenophon, who merely recorded the externals, Plato is frequently viewed as the most informative source about Socrates' life and philosophy. Meanwhile, however, many scholars (Howatson \& Sheffield 2008; Guthrie, 1971; and Santas, 1979, etc.) believe that in some works, Plato, being a literary artist, pushed his new version of "Socrates" far beyond anything the historical Socrates was likely to have done or said. In Howatson \& Sheffield's view, Plato's writings are typically in the form of dialogues in which Socrates' discusses philosophical questions with other characters of his day. Most of these are based on known historical figures, but "the dialogues are not factual accounts; they are fictional, and often richly dramatic, products of Plato's philosophical imagination" (2008, vii). Guthrie $(1971,35)$ also holds that in Plato's dialogues, it is not easy to distinguish what goes back to Socrates himself. For Strauss, it seems that in the dialogues of Plato "he has so blended his own spirit with that of Socrates that they can never again be separated" (1964, 50-51).

Certainly, Plato had reasons for doing so. The personal impact of Socrates had been for Plato such an unforgettable experience of his most impressionable years that he could see nothing improper in putting in Socrates' mouth some of the discoveries which in his eyes provided the final justification of Socrates' life and death and the answers to the questions that he had asked. In his book of Socrates, Guthrie also provides justifications for Plato: "Piety itself demanded that Plato should defend the outlook of Socrates against criticisms inherent in the development of philosophy after his death, and how could this be done without adding fresh arguments to what the living Socrates actually said?" $(1971,30)$ 
Thanks to his range, depth, and openness to development, philosophy in Plato's hands was bound to progress. When Socrates was occupied with ethical questions to the complete neglect of nature as a whole, and was seeking in them for the universal and directing the mind for the first time to definitions, Plato, accepting his teaching, came to the conclusion that it applied to something other than the sensible world: the common definition, he reasoned, could not apply to any of the sensibles, since they were always changing (Guthrie, 1971, 98). For Plato, ideas-the forms-had a genuine reality and the world could be understood through logical approaches to their meaning, without reference to the world of the senses. If the senses seemed to contradict conclusions reached from first principles and logic, it was the senses that had to be ignored. Thus, knowledge is achieved through mathematical reasoning and the perception of eternal abstract forms, something achieved by philosopher kings through a rigorous process of deductive logic (Hayhoe, 2006, 19). In his life, Plato founded the Academy in Athens so that people at that time could think about deeper meanings. It became the center of Greek learning, and it was also the first institution of higher learning in the Western world, which was later regarded as the first university.

\section{Aristotle}

Aristotle, student of Plato, was not born until 384, and he did not have the benefit of personal acquaintance with Socrates. He had, however, the inestimable advantage of having worked for twenty years in the academy under Plato's headship. 
Aristotle wrote dozens of works on many scientific disciplines. In grasping the historical significance of the Socratic Method, Aristotle has shown considerable insight. Socrates was recognized by Aristotle for introducing the study of ethics in addition to the use of inductive logic and universal (Beck, 2006, 12). Socrates' chief contribution to scientific thought was consistently regarded by Aristotle as his demand for definitions. In the Socratic search for the universal, Aristotle saw the germ of a logical method. Keenly interested in logic for its own sake, he gave Socrates (as distinct from Plato) credit for this in his own language by saying that we may fairly ascribe two things to Socrates: inductive argument and general definition (Metaph. 1978b:27).

In philosophy, Aristotle made steps further in setting rules of logic and he argued that the syllogism was its heart. Though Aristotle did not grant reality to the forms, he thought of attributes as having a reality distinct from their concrete embodiments in objects. For him it was meaningful to speak not just of a solid object, but of attributes in the abstract—solidity, whiteness, etc.-and to have theories about these abstractions. The central, basic, sine qua non properties of an object constituted its "essence," which was unchanging by definition, since if the essence of an object changed it was no longer the object but something else. The properties of an object that could change without changing the object's essence were "accidental" properties. Moreover, the Aristotelian definition of man is a "rational animal." If "man," then "rational animal"; if "rational animal," then "man" (Copleston, 1962, 125).

Apart from Plato and Aristotle, Xenophon also kept records of Socrates' life and thoughts. Other Socratic Schools known to us are: the Megarians 
(Euclid), who developed logic and eristics, and pointed out important logical fallacies; Diodorus Cronus, one of the Megarians, who discovered the anomalies inherent in the idea of possibility; the Elian School (Phaedo), who carried out dialectical investigations; the Cynics (Antisthenes), who chose the path of self-sufficiency and inner independence, while denied the importance of education and culture, and from them descended Diogenes of Sinope (Jaspers, 1957, 17).

\section{Confucian Impacts}

As a culturally symbolic figure, Confucius has left a far-reaching impact on the Chinese people, especially on the intellectuals. One cannot begin to talk about Chinese culture and education without discussing Confucius and his philosophy (c.f. Qian, 2002; Huang and Kathleen Brown, 2009). His thoughts exert great influence on the culture and history of China and some other East Asian countries like Japan and Korea.

\section{$M{ }^{157} i^{157}$ and $X u n z i^{158}$}

The two best known early interpreters of Confucius' thought — besides the compilers of the Analects themselves, who worked gradually from the time of Confucius' death until sometime during the former Han ${ }^{159}$ dynasty-are the Warring States philosophers "Mengzi" (or spelt as Meng-tzu, 372-289 B.C.E.) and Xunzi (or spelt as Hsun-tzu, 310-220 B.C.E.). Both philosophers carried on the Confucian thoughts and developed it into an effective scholastic 
tradition. Mengzi, disciple of Confucius who was also known in the West as Mencius, was often regarded as the next great figure in the Confucian tradition. Mengzi illustrated a pattern typical of Confucius' interpreters in that he claimed to be doing nothing more than "transmitting" Confucius' thought while introducing new ideas of his own. His thoughts are known best through his book, The Mencius, which presents him in conversation with the King Hui of Liang $^{160}$, covering a large range of topics relating to good governance, and meeting the needs of the people. Mengzi elaborated on the Confucian ideal by highlighting ethical attributes $\operatorname{ren}^{161}$ (benevolence, humaneness) and $\mid i^{162}$ (observance of rites). Furthermore, he added the concept of $\left.y\right|^{163}$ which means "righteousness," or "duty." Like Confucius, Mengzi regarded the transformative power of a cultivated person as the ideal basis for government. He also emphasised the ruler's duty to look after the well being of his subjects. In addition, he spelled out more explicitly the idea that the order in society depends on proper attitudes within the family, which in turn depends on cultivating oneself.

In his philosophy, Mengzi stressed the goodness of human nature. Mengzi is known for his strong faith in the inherent goodness of humankind, and the tendency of the human heart to feel sympathy for all those who may be suffering or in need. He believed that the achievement of a good society depends wholly on the inherent moral intentionality of good men (Hayhoe, 2006, 17; Schwartz, 1985, 262). Mengzi came to be regarded as

\footnotetext{
60 梁惠王

161 仁

162 礼

163 义
} 
the greatest Confucian thinker after Confucius himself, and his teachings have been very influential on the development of Confucian thought in Chinese history.

Unlike Mengzi, the later philosopher Xunzi believed human nature tended to be evil and must be restrained. Although Xunzi condemns Mengzi' arguments, Confucian traits can be also easily observed on Xunzi's thoughts; and he, too, shares the assumption that human beings can be transformed by participation in traditional aesthetic, moral, and social disciplines.

\section{Dong Zhongshu ${ }^{164}$}

After the persecution of Confucians during the short-lived Qin dynasty ${ }^{165}$ (221-202 B.C.E.), the succeeding Han emperors and their ministers grasped Confucius as a tool to legitimate their rule and the social control of their subjects. Dong Zhongshu (179-104 B.C.E.), who was the leading scholar in the time of Emperor Wu of the Western Han Dynasty ${ }^{166}$ (206-24 B.C.E.), left a giant mark on Chinese culture in that he was the first Chinese imperial scholar who put forward the propose of canonizing Confucian learning into the state ethic in the Han Dynasty. His suggestion was granted, thereby the supremacy of Confucian learning was established in China and East Asia in the next two millennia. In Dong's opinion, Heavenly rule and human rule are identical: human rule is derived from and modelled on Heaven. This correlation between human practices and heavenly behaviour gave the human practices a more transcendental authority. 
Dong Zhongshu was also a key figure in establishing the Confucian classics as the basis of public instruction. The "Five Classics" - five ancient texts associated with Confucius - were laid out at this time and were established as the basis for the imperial civil service examinations in 136 B.C.E., making memorization of these texts and their orthodox Confucian interpretations mandatory for all who wished to obtain official positions in the Han government. According to Richey in his account of Confucius of the "Internet Encyclopedia of Philosophy", this brought into being "the class of scribes who distinguished themselves not by personality but by formal learning and maintained their prestige by a system of examinations" (http://www.iep.utm.edu/confuciu/).

Confucius' high status in the country carried on to the end of the Han in 220 C.E., after which Confucius fell out of official favour as a series of warring factions struggled for control of China during the "Period of Disunity" (220-589 A.D) and foreign and indigenous religious traditions such as Buddhism and Daoism rivalled Confucianism for the attentions of the elite.

\section{Zhu $X i^{167}$}

After the restoration of unified imperial government with the Tang dynasty $^{168}$ (618-907 C.E.), the prospect of Confucius as a symbol of the Chinese cultural and political establishment became increasingly secure. State-sponsored sacrifices to him formed part of the official religious complex 
of temple rituals. In the Song dynasty ${ }^{169}$ (969-1279 C.E.), the scholar Zhu Xi (also known as Chu Hsi, 1130-1200 C.E.) inherited Confucian thoughts and argued that learning should be both individual and social; ideas were developed through participating in social discussion and not simply through memorising received thinking (Jin \& Cortazzi, 2006, 13). He also institutionalized the study of the Analects as one of "Four Books" required for the redesigned imperial civil service examinations until the early twentieth century.

\section{B. Socratic \& Confucian Influence on the Education}

Both philosophers left a measurable and lasting effect on the cultures of teaching and learning; and overall, each cultural learning orientation (despite diversity within each) has some of its origins in its own culture.

\section{Socratic Legacy}

\section{a. In Teaching}

\section{The role of a teacher: facilitator}

The roles of the teacher are defined and interpreted differently in two cultures. Socrates does not think teaching is a matter of conferring facts upon others or showering them with speeches, in large part because he does not subscribe to the "additive" view of the learning process. His mission was not to impart any body positive doctrine, but to bring home to men their intellectual 
need, and then invite them to join with him in the search for truth by the dialectical method of question and answer. He refuses to conceive of education as a knowledge transfer (cf. Symp. 175d-e and 217a). His educational approach is not designed to instil in others something that was entirely absent before, as the "additive" or "knowledge-transfer" model of pedagogy presumes to do. In his role as teacher, this philosopher knows that he can only nourish seeds that are already within his students. He is depicted in the dialogues as teaching primarily by guiding and questioning, leading others to pay attention to, to recollect, what is in some prephilophic way already within them. His teaching is designed to evoke something unique and quite personal within his interlocutors rather than to implant his own ideas in them. As long as it is understood in this way, then the term teaching may, I think, still be aptly used as a generic description of what Socrates does with many characters. " (Scott, 2000, 46)

In this view of education, which attempts to be faithful to the concept of Socratic ignorance, knowledge and ignorance are mysteriously commingled in the teacher and the students. What the teacher says can be understood only by students who are ready to "recollect" its meaning, that is, whose who are able to find its purport in themselves. Hence what the teacher endeavours to keep in memory and express in any teaching, is something the student knows also but has forgotten (Scott, 2000, 47). Socrates puts it in the Symposium, "What we call studying exists because knowledge is leaving us, because forgetting is the departure of knowledge, while studying puts back a fresh memory in place of what went away" (208a, Nehamas and Woodruff trans.). Socrates himself founded no party, made no propaganda, justified nothing, 
established no school or institution. What he did all his life was just a midwife in bringing about truth.

Socratic education is based on the principle that both the teacher and the student harbor knowledge as well as ignorance within themselves. Knowledge never exists without ignorance; therefore, even the teacher must qualify any claim to authoritative knowledge. Yet in conversation, the teacher can appeal to the knowledge buried within the student, striking a chord in him and causing a bond to be forged between them. Such resonance arises from within the student. Thus teacher and student respond to one another now as two dancers and now as two wrestlers do: the student's process of recollection guides the teacher, and the teacher's prodding and questioning leads the student further along the path of learning. The teacher learns both from self-scrutiny and from the contribution of the student, and it is important that neither controls the process, even if one leads the other. (Scott, 2000, 47)

Under the Socratic influence, Western teachers usually regard themselves as students' facilitators of learning instead of their authorities of knowledge. The Western classrooms are usually informal. Students can argue with the teachers in class. Teachers may admit their ignorance on a topic; and generally, they do not easily become angered by students' challenging questions as Chinese teachers would. They give students freedom in expressing their different ideas. They do not directly give the answer to a particular question. What they stress is students' thinking and discussion. So they encourage students to be active in classroom discussions and praise critical and daring ideas (Upton, 1989, 14; Huang \& Kathleen Brown, 2009, 649). In the Western classrooms there is an equal relationship between 
teachers and students (Huang, 2005, 558; Upton, 1989, 14; Huang \& Kathleen Brown, 2009, 648).

\section{Socratic method: question and answer}

The educational method that Socrates used is also special. Rather than teaching by means of an exposition that aims to persuade or demonstrate, the philosopher uses his style of argument to hypothesize or place in question the matters to be considered. Gerasimos Xenophon Santas observes this educational style in his Socrates: Philosophy in Plato's Early Dialogues:

"Nothing is more characteristic of Socrates than talking, and nothing is more characteristic of his talks than asking questions. Socrates is asking questions all the time. He greets people with questions, he teaches and refutes them with questions, he leaves them with questions-he actually talks to them with questions. " $(1979, x i)$

Such conversational practice, through the question-and-answer method, results both in greater self-knowledge and greater knowledge of the other. Scott describes the activity that Socrates and his interlocutor are engaged in as the most closely wrestling or a dance_- "an activity in which each participant modulates certain aspects of herself or himself in relation to the other, each comes to know the other, and at the same time greater definition is given to her or his own character through this cooperative probing and yielding" $(2000,48)$.

In this time-honoured technique of questioning and answer, the Socratic Method consists essentially in raising certain kinds of questions in seeking definitions as the first step in the quest for knowledge, and in constructing arguments by which definitions and other answers are tested (Santas,1979, xi). In using the method of questions and answers, the Socratic approach 
demonstrates that, even when the teacher knows the answer, it is sound educational method not to tell it to the students at once but to lead them to discover it step by step through the successive destruction of answers.

This question-and-answer method has several important advantages over lectures or speeches both in the educational process and philosophical inquiry, as evidenced by Plato's choice of the dialogue form for the presentation of his philosophy. First, in the Socratic Method, the same person can act as both speaker and listener in the joint deliberation or inquiry. In dialogue, one listens and speaks in the same activity; every remark contains within it the solicitation of a response (Scott, 2000, 44). Second, the question-and-answer method is easier for students to follow than long speeches. Meanwhile, the opportunity to interrupt and ask questions in order to gain further clarification is always available along the way. Third, in the Socratic Method, each participant is more thoroughly persuaded as a result of giving voice to a position herself or himself than she or he would be by merely hearing someone else assert it. Fourth, through questions and answers, the other's assent can be obtained step by step, building upon previous understanding to minimize confusion and identify clearly the points of disagreement or uncertainty between the parties. New ideas can be appropriated and tested on the spot. Finally, this mode of shared inquiry or deliberation has the intrinsic benefit of exercising the analytic, argumentative skills of both conversation partners, allowing them to give further shape to their own respective positions in and through the process of talking something through in dialogue (Scott, 2000, 44). 
In the teaching practice, the Socratic approach is based on the practice of disciplined, rigorously thoughtful dialogue. The instructor professes ignorance of the topic under discussion in order to elicit engaged dialogue with students. Since education is not a one-size-fits-all affair, the instructor can establish the background and level of his interlocutor so that he may tailor a customized approach to him. Thus, the instructor can emphasize different aspects of the same topic as he or she tailors an approach specific to different interlocutors in particular contexts.

This enquiring method of Socrates is seen as one of the first fruits of the great intellectual change that manifested itself throughout the Greek-speaking world in the second half of the fifth century, sometimes known as the Greek enlightenment. The Socratic approach values the process of generating knowledge over knowledge accepted from others, even authoritative sources. Nowadays it manifests itself in the emphasis on developing critical-thinking and problem-solving skills as the highest priority educational outcome. Socratic questioning can also be used in the training of critical thinking, which is at the heart of the Socratic tradition. Socrates refused to make his peace with the unwritten conventions of the community. He affirmed the primacy of reasonable judgment of what is right against any merely willful or arbitrary authority. In this line, people can use this way of questioning to reflect on, access and judge the assumptions underlying their ideas and actions. As it manifests itself in the emphasis on developing problem-solving skills and critical-thinking as the highest priority educational outcome, this method has influenced many other philosophers and educators in the West. 


\section{b. In Learning}

Similar mental structures have been found for the Western and Chinese conceptions of learning based on the Roschian model (Rosch, 1978). However, despite this similarity, there are big differences in the actual conceptions of learning between these two cultures.

In his education, Socrates does not typically summarize the conclusions at the end of the dialogues, nor does he often assert his own views, except in response to what various specific interlocutors say. This reticence may be partly a pedagogical device, designed to encourage the interlocutor to formulate his or her own ideas or to state without reservation whatever opinion or belief she or he might hold on the topic. But more importantly, Socrates' approach forces his conversation partner to think and express his own thoughts prior to hearing what the much more thoughtful and experienced philosopher has to say on the subject. In this way, Socratic questioning promotes what is today called active learning.

Aoki $(2006,38), \mathrm{Li}(2004,595)$ and Greenholtz $(2003,125)$ note that Western children show a heightened awareness of the mind/task attributes of the learner, that is, ability, task attempting, and strategy use. Learning is viewed as a process of acquiring the accumulated knowledge about the world and ideally using it to inquire into the unknown and to invent the new. Success is based on individual competence. At the heart of this tradition is the role of the mind along with its development and function (Gardner, 1983; Perkins, 1981; Sternberg, 1985; Tweed \& Lehman, 2002). Teachers and students place positive associations on innovative and new ideas. Students are more likely to 
speak up in a large group; conflict in learning is seen as a way of advancing ideas and knowledge; and notions of face are weak (Holmes, 2006, 23).

\section{c. Socratic Legacy \& the Individualistic-Analytical Tradition}

In the time when Socrates lived, Greeks were independent and often engaged in verbal contentions and debates in an effort to discover what people took to be the truth. They thought of themselves as individuals with distinctive properties, as units separate from others within the society, and in control of their own destinies. The traces of individualism could be found in ancient Greek literature as in Homer's epics and the chorus in the drama of Antigone, which announces the ambiguous dignity of man by delineating his distinctiveness. Similarly, Greek philosophy started from the individual object - the person, the atom, the house - as the unit of analysis and it dealt with properties of the object. For the Greek philosophers, world was in principle and knowable (Cooper, 2005, 968; Quinton, 2005, 702; Teichman and Evans, 1991, 1).

Socrates can be conceived of as both an antecedent and consequence of individualism. The salient features, which exhibit the individual uniqueness in Socrates, lie in his ordained roles as gadfly and midwife. The Greek philosopher compares himself as a gadfly, an irritating pest, who bites the horse which is Athens, serving it ceaseless by waking it up from its lethargic slumber (Plato's Apology of Socrates. West, 1979, 20). His testimony in the Apology confirms that the philosopher is interested in provoking people to move from carelessness to caring about how best to live, from being absorbed exclusively in worldly concerns to being concerned primarily with the best 
possible state of the psuchē (Scott, 2000, 169). Genuine learning begins with an examination and challenge to what one thinks one knows prior to learning. The gadfly's sting and the mental midwifery are only designed to turn people around, to reorder their concerns, and to introduce them to a regimen of self-care which might best enable them to live good and happy lives. Where the influence of Socrates is felt, men convince themselves in freedom; they do not subscribe to articles of faith. For Socrates, such vital education in citizenship and virtue defines the paideia of a free person —-the leading value he would attempt to confer.

In addition, Socrates has been viewed by Thomas G. West $(1979,11)$ as the first in a long Western tradition of philosophic rationalists. In Aristotle's account, he was the first who recognized the importance of inductive arguments and systematically used it to get general definitions ${ }^{170}$. Socrates looked to reason as a guide to life. He relentlessly refused to accept answers untested in conversation and debate and accepted "revelation" not on divine authority and not because it was supported by the laws but only insofar as it passed the test reason.

On the shifting ground of Athenian democracy, Socrates stood out, and stood firm, serenely asserting by his unshakable rationality against the troubled historical and social background. He could not accept any conventions or ready-made answers which he found incoherent himself. And he knew that he himself did not possess adequate knowledge about those most important things. Socratic skepticism challenged civic dogmatism. In order to

\footnotetext{
${ }^{170}$ The inductive arguments referred to are not scientific inductions but arguments from analogy such as we often find Socrates using in the Memorabilia and in Plato's 'Socratic' dialogues (Ross, Metaph. I. xliii and 2.422.)
} 
find out truth, Socrates, in most rounds of conversation with various interlocutors, raised questions, obtained definitions or theses from the interlocutors, and he constructed arguments by which he tested the definitions. In light of Socrates' lifelong search for knowledge about the highest questions, city's supposed certitudes come to sight as obstacles standing in the way of genuine education. Convictions that citizens hold to be final are merely beginning points for Socratic inquiry. Thus Socrates' thought is characterized by an uncompromising dedication to reason and the real knowledge. Furthermore, Thomas G. West also observes in his introduction to Plato's Euthyphro a remarkable moderation that stems from Socrates' awareness of his own ignorance--Socrates' achievement, which deserves our careful studies, was to "combine rigor with scepticism without giving in to the temptation of absolutism on the one extreme or relativism on the other "(1979, 12).

Socratic traits of individualism and rationality have an important influence on the development of philosophy, as well as the society as a whole. Clear unbroken lines of influence lead from ancient Greek and Hellenistic philosophers, to medieval Muslim philosophers and Islamic scientists, to the European Renaissance and Enlightenment, to the modern day society, particularly in the education sector. In the most of the Western countries today, personal uniqueness is widely accepted; and creativity, autonomy, self-reliance and individual responsibility have been regarded as key values in education (Triandis et al, 1990, 1008; Zhu et al, 2008, 121). Children are raised to be self-reliant and independent (Deci \& Ryan, 1985; lyengar \& Lepper, 1999; Lepper \& Malone, 1987; Markus \& Kitayama, 1991); while in school, "competition" is a major motivating factor for Western students (Zhu et 
al, 2008, 121). Western students value education as a means to improve their personal economic worth (Holmes, 2006, 23). In Western societies, receiving education and learning is treated as a highly individualistic, ego-enhancing concept. It is characterized by individual competition where the need for success overcomes the fear of failure where winning is its own reward (Watkins, 2000, 167). Meanwhile, as learning is seen mainly as a process of developing and using the mind so as to explore the world and have new inventions, Western teachers and parents attach more attention to freedom and they encourage creativity in education. That is why most Western classroom usually strikes the Chinese people as being flexible and creative (Wan, 2001, 41).

\section{Confucian Heritage}

Confucius is regarded as one of the fifty major thinkers on education (Shen, 2001, 1). The Confucian philosophy on education still has a strong impact on the current Chinese educational system. Confucius and his followers attached great importance on education and learning ${ }^{171}$, a tradition which can still be felt in China and many other neighbouring nations today.

\section{a. In Teaching}

The role of a teacher: authority

\footnotetext{
171 It has been recorded in the Analects (Bk. XIII, Ch. IX.) that when Confucius went to Wei, Ran You acted as driver of his carriage. The Master (Confucius) observed, "How numerous are the people!" You said, "Since they are thus numerous, what more shall be done for them?" "Enrich them," was the reply. "And when they have been enriched, what more shall be done?" The Master said, “Teach them.” (The Analects, Bk. XIII, Ch. IX.) (子适卫, 再有仆。子曰: “庶矣哉! ”舟有曰: “既庶矣。又何加焉? ”曰: “富之。”曰: “既富矣, 又何加焉? ”曰: “教 之。”《论语 子路第十三. 九》)
} 
Contrary to the "facilitator" image of a teacher in the West, the authoritative position of teachers has been widely acknowledged in the countries influenced by the Confucian heritage (e.g. Cummings, 1996, 292; Wing On, 1996, 30). In China, teachers are regarded as someone superior that should be respected. Confucius himself was taken respectfully as a teachers' model for all generations. In China, many Confucian temples have been built; and the imperial courts came to honour Confucius from age to age. It has been even held that the teachers, together with heaven, earth, the emperor, and parents, are the most respected authorities in traditional China (Feng, 1983, 80; He and Peng, 2009, 103; Lee, 1996, 36).

Under this influence, unlike the equality in the Western classrooms, the education in the Confucian tradition has been characterized as a hierarchical, teacher-centred system (Natascha, 2007, 42). Normally, Chinese teachers are seen not only as authorities in their field of study but also as students' moral mentors (Huang \& Kathleen Brown, 2009, 648). They are models both of knowledge and morality. They are supposed to be friendly and warm-hearted, a perception linked to the Confucian concept of 'ren' ${ }^{172}$, which translates to something like human-heartedness or love. (Jin \& Cortazzi 1998, 740; Watkins, 2000, 168). Moreover, in line with the Confucian thoughts, one's teacher is on a par with one's father in terms of the loyalty and deference that is one expected to show. In accordance with this cultural trait, teachers in the Confucian tradition find their students to be extremely deferential (Flowerdew \& Miller, 1995, 357). Students are supposed to display unquestioning acceptance of the words of the teacher. Murphy $(1987,43)$, Pierson $(1996,51)$, 
Clark and Gieve $(2005,59)$ and McGuire $(1997,11)$ observe that in such circumstances, such qualities as docility, passivity and conformity were formed in students. Coupled with this is an emphasis on strictness of discipline and proper behaviour, rather than an expression of opinion, independence, self-mastery, creativity and all round personal development (Murphy, 1987, 43; Clark and Gieve, 2005, 59).

\section{b. In Learning}

The Confucian tradition defines practical approaches to learning as careful study of a canon of texts combined with the practice of moral self-cultivation. Compared to the emphasis on the mind and abilities, Chinese students tend to perceive more the learner's dispositional qualities of diligence, persistence, and concentration, which are closely related to a perspective on Confucian heritages of learning. The need of knowledge and seeking of it require that Chinese cultivate the desire to learn adopt the action plan of diligence, endurance of hardship, perseverance, and concentration, engage in lifelong learning, and remain humble (Li, 2003, 264). Chinese learning-related values, such as effortful learning and respect for the classics, are associated with the enduring influence of Confucian teaching along with the ideas of important figures such as Mengzi and Zhu Xi, and these values still play a very important role in Chinese people' $s$ life.

Confucius stresses the importance of hard work. He believes that one's success mainly comes from his efforts. There are nearly a dozen pieces of sayings on the importance of efforts, and a typical one is recorded in Bk. VII, Ch. X IX of the Analects. When the Duke of She asked Zi Lu about Confucius, 
and Zi Lu did not answer him. The Master said, "Why did you not say to him, 'He is simply a man, who in his eager pursuit of knowledge forgets his food, who in the joy of its attainment forgets his sorrows, and who does not perceive that old age is coming on?"' (The Analects, Bk. VII, Ch. X IX.) (叶公问孔子于子 路, 子路不对。子曰: “女奚不曰, 其为人也, 发愤忘食, 乐以忘忧, 不知老之 将至云尔。”《论语 述而第七・ 十九》). Another piece of evidence is in Bk. VII, Ch. II., where Confucius proclaims, "A sage is what I cannot rise to. I learn without satiety and teach without being tired" (The Analects, Bk. VII, Ch. II.) （.....学而不厌, 诲人不倦, 何有于我哉? 《论语 述而第七.二》). These indicate the aspect of Chinese cultures of learning of making a disciplined effort.

The cultural emphasis on learning and intensifying socialisation practice for a highly competitively educational system make the attribute of efforts even more important for nowadays Chinese students. In the Chinese society, everyone is assumed to be capable of learning and achieving as long as they put in the time and effort (Pratt et al. 1999, 250). Watkins $(2000,165)$ also observes that the Chinese students normally thought of understanding as a long process that required considerable mental effort whereas the Western students saw the process as usually the one of sudden insight.

One attributing factor lies in the social and moral implications of learning in the Chinese society. Zhu et al. $(2008,121)$ reports that Chinese students reflect a strong sense of duty in learning and see learning as personal fulfillment. One is supposed to become a socially responsible and better person. If someone is perceived as refusing to learn, he or she may be regarded as socially irresponsible (for parents and family) and, worse yet, 
immoral (not wanting to strive to be good). This cultural phenomenon has also been discussed by D.Y.H. Wu and Tseng (1985), Cheng (1996) and Li (2004, 126), with similar conclusions. This helps to explain why Chinese learners have demonstrated perseverance and willingness to learn.

In addition, Confucian emphasis on self-perfection may lead Chinese to view their own personal agency for seeking knowledge more important than external conditions. Apart from the moral obligation in which one must be devoted to the accumulation of knowledge, and review what he has already learned as a path to new knowledge, one must also be assiduous at all times and must, if necessary, sacrifice food and sleep for the sake of study ${ }^{173}$. This is what is called in Chinese haoxue ${ }^{174}$, meaning putting one's heart and mind for wanting to learn. This love and passion for learning is also something special and unique in the Chinese culture of learning.

The fondness of learning also leads to a lifelong dedication. In his seventies, Confucius forgot his food and sorrows in his eager pursuit of knowledge, and did not perceive that old age was coming on. Confucius himself envisioned human perfection as the highest purpose of life and believed that it is possible for everyone who seeks it. However, such seeking necessitates a lifelong dedication and effortful learning on the part of the individual, a process called "self-perfection" (W.O. Lee, 1996; Li, 2003; Tu, 1979; Yu, 1996). Nonetheless, this pursuit still holds a strong appeal to Chinese intellectuals today.

\footnotetext{
${ }^{173}$ It has now become the Chinese idiom, 废寝忘食, which literally means “sacrifice food and sleep for the sake of study."

174 好学
} 


\section{c. Confucian Heritage \& the Collective-Intuitive Tradition}

First, the collective trait displays itself in the motivation of education. Compared to the ego-oriented motivation of learning in the West, the Chinese achievement motivation is more social. Zhu et. $(2008,121)$ and Triandis et al. $(1990,1008)$ discover that in East Asian societies influenced by the Confucian heritage, the notion of success needs to be reinterpreted in a collectivist framework which may involve significant others, the family, peers, or even society as a whole. First, as discussed above, learning in the Confucian tradition is primarily viewed not as a task but first and foremost as a process of self-perfection through which the learner cultivates himself or herself socially and morally (Lee, 1996, 36). Knowledge, accordingly, includes not only the externally existing body but also social and moral knowing, which is also expressed in the concepts of ren ${ }^{175}$ and $j u n z i^{176}$ in Confucian thought, that is, becoming the most sincere, genuine, and humane person one can become ( $\mathrm{Li}, 2004,595)$. Apart from the self-development, the individual is also supposed to work for the entire family. Education is valued as the key to an improved (and more affluent) future. In China today, people still believe that only college graduates can possess a high status in society. A good education can bring honour to the family and even the community. Parents feel honoured if their children can go to colleges and universities. If their child's education is prestigious and/or successful, parents may gain status among their peers (Holmes, 2006, 23). The pressure to succeed academically is there for all 
children irrespective of the parent's educational level and is very much a matter of "family face" (Watkins, 2000, 167).

Furthermore, in Confucius thought, education is a way for one to ultimately become a useful person to the state. Confucian principle that "those who excel in office should learn; those who excel in learning should take office" (The Analects, Bk. IXX, Ch. XIII.) (“仕而优则学, 学而优则仕。”《论语 子张第 十九・十三》) has guided Chinese education. This principle provided justifications for the imperial examinations over a thousand years in China (Huang \& Kathleen Brown, 2009, 645). In the Confucian tradition, a promising young man was expected to study for the government examinations with the hope of becoming a magistrate. If he did, his whole family benefited economically from his position. Moreover, education also means responsibility for government and society. The purpose of receiving education is also to give back one's knowledge to society in the end; and serving the community is part and parcel of one's learning. This concept of contribution to society reveals the idea of social consciousness.

Thus, gaining social respect and status for oneself, the family and contributing to society constitute the social dimension in the motivation of learning in the Confucian tradition. Regarding one as a sociocultural being, learning, therefore, aims at the unity of knowing and morality, and contribution to society in addition to mastery of academic subjects and utilitarian purposes (Lee, 1996, 36; Li 2003, 264).

The Confucian notion of hierarchy has also framed the Chinese culture. In Confucius' teaching, the concepts of filial piety, loyalty, and rules of proper conduct assume essential importance. These are the values and principles 
upon which traditional Chinese culture built, indicating a linear hierarchy characterized by various dominance-obedience relationships: men dominating women, old dominating young, and the emperor dominating everyone else. Within the Chinese family, the parents normally have authority over their children and the children are supposed to respect their parents. In the Confucian value of filial piety, children are expected to fulfill the wishes of their parents where choice of study is concerned. The hierarchical order (father and son, husband and wife, old and young family members) governs the interaction in the family. In the society it is the Chinese moral standard that the children should always show respect for the older people; and persons of lower social status should be loyal to the authorities. Such collectivist values as conformity, obedience, duty, and sacrifice for the ingroup are emphasized. In such a society of complexity and interrelation, it is not freedom but harmony that is the watchword-the harmony of humans with other humans for the Confucians. According to Confucius, harmony is delightful and enduring (The Analects, Bk. I, Ch. XII); and it remains to be a catchword in the contemporary Chinese society.

The learning cultures are usually embedded in social dimensions. Confucius attached much importance to self-examination and proper behavior (ref. the Analects, Bk. 9 Chap. IV.). The Chinese philosopher himself is a modest man. No doubt, in his time, Confucius could compete with others in learning, but he recognized that he had not attained the level of the superior man who can transform his knowledge into action. "Of myself I can only say 
that I have striven insatiably to become so, and that I teach others untiringly ${ }^{177 "}$ (The Analects, Bk. VII, Ch. II \& XXXIV); and proclaimed that he was only "a transmitter and not a maker, believing in and loving ancient studies ${ }^{178 " \text { (The }}$ Analects, Bk. VII, Ch. I). Under this influence, whereas Western students value more on self-expression, Chinese students tend to emphasize self-control. The literature in Moneta $(2004,187)$ and Triandis et al. $(1990,1007)$ also confirm that Chinese students learn more behavioural rules than Westerners do, and they tend to consider them all before reacting to a stimulus. In addition, as we have discussed above, the teachers are regarded as the authorities in the schools. Confucius held one should honour and respect authorities (The Analects, Bk. XIV, Ch. X; Bk. II, Ch. XX and Bk. XIII, Ch. IXX). In this view, the students should always respect the teachers. This also explains why in Chinese culture, the teachers are always regarded as a model of knowledge and virtue for the students (Huang \& Kathleen Brown, 2009, 645). Besides, Chinese children were expected to show a greater sensitivity to social assistance, particularly adult advice, because moral/virtue guidance is widely available and integrated in children's learning activities (Li, 2004, 596). In this case, teachers do not only teach the students knowledge but also help students in their personal life, and even in choosing their future careers. As a Chinese saying goes "One day's teacher, a lifetime master," which means students should always respect the teacher no matter how long he teaches them, teachers can be very influential in Chinese students' lives.

177 学而不厌, 诲人不倦 
Whereas Socrates promoted reason and rationality, and followed "the one, and truth itself," the Confucian view of knowledge developed in the way very differently. For Confucius, knowledge begins with "the empirical cumulative knowledge of masses of particulars and then includes the ability to link these particulars first to one's own experiences and then ultimately with the underlying 'unity' that binds this thought together" (Schwartz, 1985, 89). The Chinese philosopher emphasized on harmony, holism, and the mutual influence of everything on almost everything else-knowledge as a process of absorbing and interacting with experience, and human development as a way of harmonizing the self with heaven, human society and the world of nature. The Confucian thoughts are very much in line with the Chinese culture, in which the most concrete sense impressions are favoured in understanding and describing the world. A typical example in case lies in the Chinese language, where there is no suffix equivalent to "ness" in Chinese. So there is no "whiteness" - only the white of the swan and the white of the snow. Instead of precisely defined terms or categories, expressive, metaphoric language is preferred in the Chinese language and culture.

One important concept raised by Confucius is ren ${ }^{179}$, usually translated as human-heartedness. Prof. Liang Souming, a distinguished philosopher in modern China, in his masterpiece Eastern and Western Civilizations and Their Philosophies (1922, not translated into English) defines ren as "intuition". In spite of the obscure, and perhaps misleading nature of the term "intuition," his definition is significantly illuminating because it suggests "the immediacy, directness, and spontaneity of ren" (Guthrie, 1971, 168). Ren 
as intuition is a kind of moral insight that results from an ethical education and a life experience that provides a reliable evaluation of the scene of life. It is not an inborn intuition but one cultivated through the practice of li, the attainment of knowledge.

\section{Summary}

In the Apology (West, 1979, 39), Socrates utters a prophecy: if the Athenians think that by silencing him they will escape future censure, they are wrong. Others will speak, of whom as yet they know nothing because his authority has restrained them, and being young they will speak all the more harshly. Socrates' prediction was confirmed. His friends would leave the Athenians no peace. Plato (still in his twenties when Socrates died), Aeschines, Antisthenes, Xenophon and others, poured out so many writings to his memory. Although the Greek philosopher himself had left no work, no doctrine, much less system, he gave impetus to the mightiest movement in Greek philosophy, a movement that has endured down to today.

Plato, the favourite student of the philosopher, transmitted the main stream of Socratic thoughts. Out of his love and admiration for his teacher, Plato was thought of merging his own spirits and thoughts when portraying his teacher in the "Socratic conversations" in the eyes of many literary critics. Yet Plato is a more sophisticated philosopher and marks a new development in the history of thought. He holds that knowledge is achieved through mathematical reasoning and the perception of eternal abstract forms, something achieved by philosopher kings through a rigorous process of deductive logic. He was also the founder of the Academy in Athens, antecedent of the modern 
university. Aristotle, another distinguished philosopher and student of Plato, recognized Socrates for his contribution in inductive argument and general definition. As a philosopher whose interest was purely abstract and philosophical, he made steps further in setting rules of logic and he argued that the syllogism was its heart. Socrates and his students, Plato, Aristotle and other philosophers, helped to lay the foundations of Western philosophy and science.

Confucius and his followers have largely influenced Chinese society in general and education in particular. The two best known early interpreters of Confucius' thought are Mengzi and Xunzi. Neither knew Confucius personally, but they were deeply influenced by the Confucian thoughts and teachings. Mengzi developed on Confucian ethical values of ren and $I i$; and added in the concept of yi. Later in the Han Dynasty, Confucian philosophy became important as Dong Zhongshu canonized it into the state ethic in order to legitimate the emperors' rule and the social control of the subjects. In the later Song dynasty, another well-known Confucian scholar Zhu Xi inherited the Confucian principles and argued that learning should be both individual and social. He also institutionalized the study of the Analects as one of "Four Books" required for the redesigned imperial civil service examinations until the early twentieth century.

Both philosophers have an immeasurable and lasting effect on the educational practices in their different traditions. First, the roles of a teacher are defined and interpreted differently in two cultures. In his role as teacher, Socrates knows that he can only nourish seeds that are already within his students. So he primarily educates people by guiding and questioning. Under 
the Socratic influence, Western teachers usually regard themselves as students' facilitators of learning instead of their authorities of knowledge. In the Western classrooms there is an equal relationship between teachers and students. In addition, in terms of teaching method, the Socratic Method consists essentially in raising certain kinds of questions in seeking definitions as the first step in the quest for knowledge, and in constructing arguments by which definitions and other answers are tested. This question-and-answer method came into written form in the philosophical dialogues of Plato, in which both teacher and student become co-seekers after truths. Nowadays it manifests itself in the emphasis on developing critical-thinking and problem-solving skills as the highest priority educational outcome. Socratic questioning can also be used in the training of critical thinking, which is at the heart of the Socratic tradition. In this tradition, the Socratic Method promotes what is today called active learning. Western children show a heightened awareness of the mind/task attributes of the learner, that is, ability, task attempting, and strategy use. For them, success is based on individual competence.

Confucius and his followers have largely influenced Chinese society in general and education in particular. Contrary to the "facilitator" image of a teacher in the West, the authoritative position of teachers has been widely acknowledged in the countries influenced by the Confucian heritage. In China, teachers are regarded as someone superior that should be respected. Under this influence, unlike the equality in the Western classrooms, the education in the Confucian tradition has been characterized as a hierarchical, teacher-centred system. Coupled with this is an emphasis on strictness of 
discipline and proper behaviour, rather than an expression of opinion, independence, self-mastery, creativity and all round personal development. Values and conforming behaviours are encouraged over exploration and deviation from the established norms. Compared to the emphasis on the mind and abilities, Chinese students tend to perceive more the learner's dispositional qualities of diligence, persistence, and concentration, which are closely related to a perspective on Confucian heritages of learning. Chinese students were much more likely to attribute academic success primarily to efforts rather than to ability, like Western students. The need of knowledge and seeking of it require that Chinese cultivate the desire to learn adopt the action plan of diligence, endurance of hardship, perseverance, and concentration, engage in lifelong learning, and remain humble. There is a general believing that learning is a moral duty and studying hard is a responsibility to the family and society. The fondness of learning leads to a lifelong dedication, which still holds a strong appeal to Chinese intellectuals today.

Socratic traits of individualism and rationality have been embedded in the Western educational practice. The salient features, which exhibit the individual uniqueness in Socrates, lie in his ordained roles as gadfly and midwife. Socratic individualism consists in taking oneself seriously as an object of existential and moral inquiry. Ancient Greek philosophers focused on the role of reason and inquiry, and so did Socrates. Socrates used a reasoning approach. In the refutation and dialectical methods Socrates surpassed Confucius in his ability to reason. In this line, in the most of the Western countries today, personal uniqueness is widely accepted; and creativity, 
autonomy, self-reliance and individual responsibility have been regarded as key values in education. In Western societies, receiving education and learning is treated as a highly individualistic, ego-enhancing concept. It is characterized by individual competition. Western teachers and parents attach more attention to freedom and they encourage creativity in education.

The Confucian heritage and the collective-intuitive tradition have also greatly shaped the Chinese educational tradition. The collective-intuitive tradition displays itself in the motivation of learning. Compared to the ego-oriented motivation of learning in the West, the Chinese achievement motivation is more social. If knowing the world and individual improvement are the ultimate purposes for most Western students, then, Chinese students must study for "social approval" and responsibilities to their families and society as a whole. The Confucian notion of hierarchy has also framed the Chinese culture. Students are taught to respect and obey authorities; and proper behaviour is emphasized. With regard to values, collectivistic cultures such as the Chinese, put forward the cardinal values of conformity, obedience, duty, sacrifice, interdependence and harmony, compared to creativity, bravery, self-reliance and individual responsibility stressed by individualistic cultures. The Chinese intuitive tradition also left impacts on education. The role of an exemplar and citing from poems are still more effective education methods than reasoning. Nowadays tremendous impacts of the influence of the Confucian heritage still can be seen in the education sector.

While the practice of education is 'value-laden' and a contested concept: different individuals and groups conceptualise it in different ways (Scott, 1996, 155), it is problematic for educational researchers who are themselves 
products of an educational tradition to take a value-neutral or value-free

position when looking into culturally embedded educational practices. Usher's

(1996) notion of double hermeneutic offers a useful explanation:

Research involves interpreting the actions of those who are themselves interpreters: it involves interpretations of interpretations - the double hermeneutic at work. Understanding an object (other people) is always 'prejudiced' in the sense that it can only be approaches through an initial projection of meaning. This initial projection is from the subject's (the researcher's) situatedness, from the subject's standpoint in history, society and culture. (Usher, 1996, 20-21) 


\section{CHAPTER VI. CONCLUSION}

\section{A. Summary of the Dissertation}

Socrates and Confucius were the philosophers lived around the fifth and fourth centuries B.C.E. They are the paradigmatic individuals who have exerted far-reaching influence on the Western and Eastern civilizations; and they represent very different cultural values and learning traditions.

Despite the availability of volumes of works about these two philosophers, the comparative study of their educational philosophy itself has received little attention. Rare are references in the literature about the two philosophers from cultural perspectives. Due to limited existing literature and studies on Confucius in the Western academia, partial knowledge or even some misunderstandings may arise about this ancient Chinese philosopher. The lack of knowledge of the eastern historical and cultural background may also give rise to the stereotypes of Asian students which may even bring conflict in the form of racism and prejudice.

One important objective of the dissertation is to capture the essence of the ancient philosophers and introduce them to readers who do not know much about their thoughts. Secondly, this study takes a cross-cultural perspective. An understanding of the two philosophers' thoughts in the cultural contexts may help us recognize both differences and common ideas in the tradition of education in the West and East. It is hoped that understanding of 
both the West and Chinese academic circles about each other's tradition of thoughts will be enhanced.

The method employed in the study is hermeneutics, or interpretation of the literary texts. At the same time, the study is also cross-cultural in nature. We try to put the two philosophers' thoughts in their own cultural contexts, and attempt to understand their roots in the socio-cultural climate. Such a perspective is chosen to analyze and interpret the data collected in this study because it is hoped that looking at the phenomena from both sides will generate deeper understanding.

As for the source materials used in this study, for Socrates, the writings of Xenophon Memorabilia, Apology, Symposium and early dialogues of Plato Euthyphro, Apology, Crito are selected as the source material in this study. For Confucius, the primary source used in this study is Lun $Y u$, or the Analects, which records the words and deeds of Confucius and his disciples in the form of quotation and dialogues.

In Chapter II, the author first identifies the definition of philosophy, and philosophy of education. The definition of the basic concepts is followed with an overview of the life and an outline of Socratic and Confucian philosophy and their educational thoughts. Socrates used the question-and-answer technique in his search for true knowledge; and the Socratic Method, has been regarded as perhaps one of the earliest teaching strategies ever described in education history. In Confucian philosophy, he called for a lifelong pursuit of love or humanheartedness; and he also taught the importance of courtesy and moderation in all things. These ultimately led to harmony and order, which were Confucius' goals. In education, Confucius attached high importance on 
efforts and the love of learning. For the Chinese philosopher, education is taken in terms of cultural transmission, service to society, and moral transformation. Then, the strength and weakness of the previous studies on Socrates and Confucius' educational philosophy and pedagogical methods are discussed. At the end of this chapter, the author presents an overview of the related terminologies, i.e. the concepts of teaching and learning, and the working definition of the West and the East, the definition of culture and cultures of teaching and learning.

In the following core chapters of III, IV, and V, the dissertation tries to answer the following questions:

- What was the social and cultural context that formed Socratic and Confucian philosophy of education?

- What were the philosophies of education for Socrates and Confucius? How were they different?

- What are the impacts of their educational philosophy on the Western and Chinese education?

In Chapter III, the respective historical, social and cultural contexts in Ancient Greece and ancient China are presented, so as to put the philosophers into the settings in their own historical background. In the Ancient Greece, the fragmentary nature in geography led to regionalism and the increased frequency of regional conflicts. Athenian society in the sixth century B.C.E. developed increasingly open and democratic institutions resulting, by the fifth century, in the most radically democratic government the world has seen. At the preliminary stage of civilization, most Greeks were dependent upon the benevolence of nature and needed the religious power in their life; 
the most influential oracle at that time was at Delphi. The fragmentary geographical nature and the democratic government contributed to the unique cultural traits; and certain values such as achievement, competition and self knowledge were emphasized in the society. The individualistic strain led the Greeks to high levels of creative thinking in a number of fields such as literature, science, and architecture. The epics of Homer, the plays of Aeschylus, Sophocles, Euripides and Aristophanes, the mathematical discoveries of Pythagoras, Euclid, and Archimedes, and achievements in architecture are the works created of lasting significance. At the same time, the Greek's fascination with rational inquiry began with the pre-Socratic philosophers (Thales, Heraclitus, and Pythagoras, etc.), who preferred reason and logic above observation and experience. All these exerted great influence on the shaping and development of Socratic philosophy.

Unlike the fragmentary ancient Greece, the Chinese kingdoms ruled over large territories. Like Socrates, the age in which Confucius lived was characterized by great socio-political unrest. By this period, the mighty Zhou dynasty had degenerated into a system of loosely-bound feudal states that were engaged in continuous and interminable warfare. Meanwhile, the increase of production, cities, wealth, and travelling facilities gave rise to the number and importance of the middle class people in society. During the Zhou period many people in the shi class studied in order to occupy positions of rank and hence they could advise kings and rulers on the right way to behave. Among them, the most important one was Confucius. Besides the political, economical and social background, the ancient Chinese view of the world was also introduced. For them, the universe was created not by divinities but 
self-generated from the interplay of nature's basic duality: yin and yang. This system was recorded and elaborated in the I Ching, or The Book of Changes, which greatly influenced the ancient Chinese philosopher Laozi and his work Taode Jing in the sixth century B.C.E. In the great intellectual upheaval beginning from the Spring and Autumn period (c. 770 B.C.E.), there were other various writings produced during this period; and they were generally grouped under six headings, known as the Liu Yi, or "Six Disciplinary of Arts", namely, Poetry, Documents, Rites, Music, Changes, and Annals, which formed the basic literature at the time of Confucius. The Chinese traditionally viewed society as being the source for the circumscribing characteristics of the individual. In this agricultural culture, collectivism and conformity have been the core values. By way of paradox, analogy, and appropriation of ancient sayings, the Chinese early philosophical trend resorted more to intuition than reason, as shown in I Ching, or The Book of Changes, Laozi's Taode Jing and other early Chinese literary writings. All these social and cultural elements were woven in the Confucian thoughts.

Chapter IV discusses similarities and differences in Socratic and Confucian education philosophy respectively in the aim of education, the content of education, the teaching process and the nature of education. First, the goals of education for both Socrates and Confucius were to help themselves and others in self-improvement. For Socrates, the purpose of education was to find truth within oneself. Due to special historical contexts and personal reasons, Confucius aimed more on helping his students become future statesmen and thus realizing his own political ideals. Compared with the 
individualist views of Socrates, such aims of Confucius had more social dimension.

In the content of education, both Socrates and Confucius showed great interest in moral truth, or the practice of right living and they had long discussions on ethics and virtues. While Socrates showed more concern on the individual's need and the health of one's own soul, the Chinese philosopher Confucius showed more interest in concepts like loyalty, filial piety, and rules of proper conduct. Confucius called for a personal cultivation that involved achieving inner equanimity and outer integrity and responsibility to society. He stressed the importance of order and harmony in the society.

In the process of education, both of them shared similar views on the wide selection of their students/audiences; and both educators possessed the capacity to speak differently to different audiences. Socrates did not claim to teach, so he did not charge any tuition fees; while as a real teacher, Confucius accepted the tuition fee, and built up a comprehensive and refined teaching system. In effectively using similes, metaphors, analogies, and parables, Confucius adopted "heuristic education" and his teaching methods were flexible and diversified. Confucius also argued the importance of learning by following exemplar, and put forward many effective learning strategies such as the love of learning, reviewing and reflection and applying the knowledge in practice. In comparison, Socrates did not claim to be teaching, nor did he adopt various teaching methods. His main method was his dialectic questioning, which was a dialectic process of question and answer to elicit truth. 
In addition, as for the source of knowledge, Socrates held that knowledge or truth lay in the SELF, while Confucius maintained that one could only learn knowledge from OTHERS, or from outside. The preferred ways of learning for Socrates were to ask and think, because for him knowledge was achieved through reasoning and the perception of eternal abstract forms, through a rigorous process of logic. But for Confucius, knowledge began with the empirical accumulation of masses of particulars, so he preferred to learn through listening and reading what is good. Due to different cultural backgrounds, the two philosophers also differed in their attitudes towards the past, customs and authorities: Socrates relentlessly questioned customary notions and encouraged people to have their own individualistic judgment. In contrast, Confucius showed great admiration to the past, stressed conformity to the time-honored rituals and traditions and the importance of following the great men and sages.

Both philosophers also differed in their views in the nature of education. For Socrates, to educate meant to "philosophize", and to help people know themselves. Socrates had no ready-made system of ethics to impart. Rather, he was portrayed as the uncompromising searcher after truth. The profoundest interpretation of Socrates, his irony and nonknowledge, and of his philosophizing, served not as a communication of truth, but as a goad to look for the truth. In the process of a continuous quest, his ordained roles as gadfly and midwife also stimulated other men searching. In contrast, to Confucius, the same concept of education referred to teach, or to 'instruct', or to transmit and impart knowledge. The Chinese philosopher regarded himself as "a transmitter and not a maker, believing in and loving ancient studies." He 
provided students with books by selecting ancient texts, documents, songs, oracles, codes of manners and customs, and reworking them with a view to truth and effectiveness. He had a well built-up and refined system of teaching. Moreover, Socrates believed in rationality and attempted to establish the ethical system based upon human reason and placed importance on the primacy of knowledge. In contrast, Confucius claimed faith in Heaven and relied on an intuitive approach in recognizing the value of the truths. While Socrates questioned the definition of virtue, Confucius had belief in the learning of virtues. The best way to teach, for Confucius, was by example. Furthermore, Socrates emphasized individuals and valued self-generated knowledge. Socrates stressed the distinctiveness of individuals, and argued that knowledge should not be accepted without question from 'authoritative' sources; rather, each person had to find their own truth within themselves. For him, this was the genuine education. Unlike Socrates, who fought against conventions in safeguarding his own free will, Confucius seemed more like an erudite guardian of tradition instructing his disciples to emulate the sages of the past with strong sense of social responsibility and commitment. Finally, while Socrates employed a negative method of hypothesis elimination, and striped people's belief in his inquiries, the teaching process of Confucius was positive, which brought about order and harmony to the society and helped to consolidate the political and social system.

It is concluded that individualistic and rationalist traits were embedded in Socrates' education, while Confucius' teaching was distinctively marked with collective and intuitive characteristics. Their thoughts were the products of 
their own culture, and at the same time, the thoughts of philosophers also left great impacts on the development of each culture.

In Chapter V. the implications of their education philosophy are examined. Both philosophers not only had great influence on their disciples, their philosophy of education also had deep impacts the Western and Chinese educational practice as a whole.

Disciples of Socrates, Plato, Aeschines, Antisthenes, Xenophon and others, recorded in their writings deeds and speeches of the Greek philosopher. Among them, Plato, the favourite student of the philosopher, transmitted the main stream of Socratic thoughts. He was also thought of merging his own spirits and thoughts when portraying his teacher and had his own remarkable achievement in developing philosophy. Aristotle, another distinguished philosopher and student of Plato, recognized Socrates for his contribution in inductive argument and general definition. As a philosopher whose interest was purely abstract and philosophical, he made steps further in setting rules of logic and he argued that the syllogism was its heart. Socrates and his students, Plato, Aristotle and other philosophers, helped to lay the foundations of Western philosophy and science.

Two best known early followers of Confucius were Mengzi and Xunzi. Mengzi developed on Confucian ethical values of ren and $l i$; and added in the concept of yi ("righteousness," or "duty"). Mengzi and Xunzi are usually cast as being opposed to one another because of their disagreement over human nature. Later in the Han Dynasty, Dong Zhongshu canonized the Confucian philosophy into the state ethic in order to legitimate the emperors' rule and the social control of the subjects. In the Song dynasty, another well-known 
Confucian scholar Zhu Xi inherited the Confucian principles and argued that learning should be both individual and social.

Both philosophers also have an immeasurable and lasting effect on the educational practices in their different traditions. Socratic teaching was designed to evoke something unique and quite personal within his interlocutors. Under his influence, Western teachers usually regard themselves as students' facilitators of learning instead of their authorities of knowledge. In the Western classrooms there is an equal relationship between teachers and students. In terms of teaching method, the Socratic Method has several important advantages over lectures or speeches. In the teaching practice, this approach is based on the practice of disciplined, rigorously thoughtful dialogue. Nowadays it manifests itself in the emphasis on developing critical-thinking and problem-solving skills as the highest priority educational outcome. In this tradition, Western students show a heightened awareness of the mind/task attributes of the learner, that is, ability, task attempting, and strategy use. For them, success is based on individual competence.

Confucius and his followers have largely influenced Chinese society in general and education in particular. Contrary to the "facilitator" image of a teacher in the West, the authoritative position of teachers has been widely acknowledged in the countries influenced by the Confucian heritage. In China, teachers are regarded as someone superior that should be respected. Under this influence, unlike the equality in the Western classrooms, the education in the Confucian tradition has been characterized as a hierarchical, teacher-centred system. Values and conforming behaviours are encouraged 
over exploration and deviation from the established norms. Compared to the emphasis on the mind and abilities, Chinese students tend to perceive more the learner's dispositional qualities of diligence, persistence, and concentration. The need of knowledge and seeking of it require that Chinese cultivate the desire to learn adopt the action plan of diligence, endurance of hardship, perseverance, and concentration, engage in lifelong learning, and remain humble.

Socratic traits of individualism and rationality have been embedded in the Western educational practice. The salient features, which exhibit the individual uniqueness in Socrates, lie in his ordained roles as gadfly and midwife. Socratic individualism consists in taking oneself seriously as an object of existential and moral inquiry. Ancient Greek philosophers focused on the role of reason and inquiry, and so did Socrates. Socrates used a reasoning approach. In the refutation and dialectical methods Socrates surpassed Confucius in his ability to reason. In this line, the key values of creativity, autonomy, self-reliance and individual responsibility have been stressed in education in most of the Western countries today. In Western societies, receiving education and learning is treated as a highly individualistic, ego-enhancing concept. It is characterized by high individual competition. Western teachers and parents attach more attention to freedom and they encourage creativity in the classroom.

The Confucian heritage and the collective-intuitive tradition have also greatly shaped the Chinese education. The collective trait display itself in the motivation of learning. Compared to the ego-oriented motivation of learning in the West, the Chinese achievement motivation is more social. There is a 
general believing that learning is a moral duty and studying hard is a responsibility to the family and society. In East Asian societies influenced by the Confucian heritage, the notion of success needs to be reinterpreted in a collectivist framework which may involve significant others, the family, peers, or even society as a whole. The Confucian notion of hierarchy has also framed the Chinese culture. Students are taught to respect and obey authorities; and proper behaviour is emphasized. The role of an exemplar and citing from poems are still more effective education methods than reasoning. Nowadays tremendous impacts of the influence of the Confucian heritage still can be seen in the education sector.

\section{B. Contributions/ Significance of the Study}

Socrates and Confucius respectively constitute roots of Western and eastern civilization. To supplement the existing body of studies of the two philosophers, a comparison of their educational philosophy has been undertaken from the cultural perspective. It is hoped that through the study of cultural contexts, the educational philosophy of two philosophers and the implications on the current educational practice, it can help readers achieve a much better understanding of the two philosophers themselves.

This paper helps introduce Socrates and his thoughts to the Chinese readers. At the same time, the research is especially significant in bringing the Chinese philosopher Confucius to the West. Biggs $(1996,45)$ and Cheng $(2000,435)$ while drawing on Confucian heritage discourse, argue that the West may not have fully grasped the significance of Confucius and his thoughts. The Confucian thoughts are regarded especially important when 
people rethink of the enlightenment heritage, with progress, reason and individualism being developed into self-interest, expansionism, domination, manipulation and control (Hayhoe, 2006, 3). The dialogue of civilizations opens up the opportunities for a global appreciation of Eastern thought. The status and people's reception of Confucius have gone through ups and downs in the history. Today, with the substantial development of Chinese economy and the growth of the country's influence in the world, Confucius, as a cultural symbol of Chinese culture, has attracted increasing attention; and the studies of this Chinese philosopher have special importance.

The knowledge about the philosophers and their respective cultural contexts will certainly support an ability to decentre and understand otherness and self. Besides the philosophers and their ideas on education, this paper is also significant in introducing different educational traditions, which have great impacts in shaping the current world of education. In an ever increasing multicultural classroom, often students are from various cultures, and Chinese students constitute a growing percentage of the whole student population. Chinese students, whether from Singapore, Hong Kong, China, or anywhere else in the world, share the same Confucian cultural heritage which influenced their attitudes to and methods of learning. We do not, of course, claim all Chinese students are the same, but we do believe based on the evidence from literature (e.g. Watkins \& Biggs, 1996, 171) that many Chinese students, because of their cultural heritage, approach education in a different way from most Western students.

Thus, a teaching or learning approach that is taken for granted and regarded as universal and common sense by people from one culture may be 
seen as idiosyncratic and ineffective in the eyes of people from a different culture. It is always important for teachers to be aware of the interplay between Western conceptions of education and students from other educational traditions for successful intercultural communication to take place. If differences in learning cultures are not acknowledged, international students may suffer stress from cross-cultural misunderstanding and finding their needs unmet. They may feel disenfranchised from the host culture. Therefore, teachers should be conscious of the potential misunderstandings that may arise from different interpretations of events due to cultural differences. It is crucial for educators to adopt a reflexive approach to students and be sensitive to issues in educational and cultural contexts of their own and of students from different cultural background. It will be more significant if educators can assist these students by becoming aware of their home culture, different learning styles, frustrations in adjusting to school life and in overcoming cultural shocks.

Educational practice must be understood from multiple perspectives. This research indicates that culture serves as an important source of variation in human learning processes and achievement. This study takes a cultural perspective and produces findings that shed some new light on the meanings students construct about learning as they develop in their respective cultures. It is suggested that cultural contexts should always be taken into consideration when studying a particular teaching or learning style.

Both Socrates and Confucius constitute the global heritage. This paper undertakes to communicate aspects of their heritage within a comparative perspective. In this period of dialogue among civilizations, such a comparative study is significant in that they provide an opportunity for critical self-reflection 
and self-awareness, and help to rationalize our own cultural, historical, or philosophical biases, just as Reagan observes:

... given their [non-Western educational traditions] differences from the Western tradition, it is essential that we all learn to invite and to listen to the 'multiple voices' and perspectives that can enlighten our understanding of these traditions, just as we must learn to recognise that different groups may, as a consequence of their sociocultural contexts and backgrounds, possess 'ways of knowing' that, although different from our own, may be every bit as valuable and worthwhile as those to which we are accustomed. (Reagan, 2000, 2)

\section{The Possible Limitation and Final Remarks from the Author}

The present study is affected by possible limitation. That is, because of the antiquity of Confucius and Socrates, the historical difficulties are immense. We must rely on the written documents of other ancient writers, and the historical accuracy of those available is questionable and controversial. First, there is the "Socratic problem" - the difficulty of distinguishing the historical Socrates from the Socrateses of the authors of the texts in which he appears. This is inevitable, since Socrates himself wrote nothing, and all that we know about him and his thoughts comes from the writings of men of the most varied character, from philosophers to comic poets, some of whom were passionately devoted to him while other thought his influence pernicious. Each age, each intellectual turn, produces a Socrates of its own. This diversity in the Socratic tradition began with his death and has never ceased; and it explains why there is still disagreement about the reality of Socrates. The same problem exists with the Chinese philosopher too. It also seems impossible to arrive at a reliable picture of the historical Confucius through the layers of tradition that

obscure it (Jaspers, 1957, 41). This ambiguity and lack of reliability may serve 
as the modern basis of criticism. The problem of the historic philosophers is, I believe, insoluble, but the quest to find the meaning of their ideas for ourselves is perennial. If every one must have his or her own personal Socrates and Confucius, I can do no more than present mine. It has been based on the fairest assessment of the evidence and texts of which I am capable. The conclusion also comes from the examination of the historical and cultural contexts in which they lived. The copious texts which shared in common must have a core of truth.

Moreover, we should point out at, although we use it as our starting point, culture is not the only determinant of teaching and learning preferences and experiences. One must guard against over-reliance on such cultural information, and avoid the trap of simplification of the complex and dynamic phenomenon of teaching and learning. Many dimensions of this dynamic process remain essentially unexamined. As a matter of fact, Chinese and Western teachers and students do not form homogeneous groups. Specific groups, for example Chinese-Americans, may have their own traits and characteristics. Even within one society there are inconsistencies: individual differences such as gender, age, geographical identity (e.g. rural/urban, and north/south), the family backgrounds and goals, specific motivation for learning, and the nature of the relationship between teachers and learners, are also influential. Thus, King $(1962,16)$ suggests that in every country there are problems of "divided culture", and that learning behaviours are more likely to be context-bound or individually based than defined by nationality and ethnic groups. These concerns require further and prolonged investigation that is 
context-specific, and that also accounts for the idiosyncratic and the individual in the pluricultural learning environment.

Finally, we should be aware of the fact that all analytical frameworks are by nature simplifications of reality. The readers should be alert to the fact that in this paper, we are not trying to evaluate any culture, nor should we fall in the trap of oversimplification in the analysis. The author is fully aware of the dangers of bicultural comparisons. Sometimes the two philosophies of education are presented in the form of dichotomies in order to present a clearer demonstration and easier comparison, but this does not necessarily mean that the Socratic and Confucian approaches to learning are always opposing, or bipolar. As a matter of fact, their philosophies of education can complement and supplement each other; and it is especially true in today's multicultural world. 


\section{REFERENCES}

Abbs, Peter. Socratic Education. Ed. Alan McClelland. London: UHP, 1993.

Aoki, Kumiko. "Confucius vs. Socrates: The Impact of Educational Traditions of East and West in a Global Age.” The International Journal of Learning 14.11 (2006): $35-40$.

Barbieri-Low, Anthony J. Artisans in Early Imperial China. Seattle \& London: University of Washington Press, 2007.

Bartlett, Robert C. Shorter Socratic Writings: Apology of Socrates to the Jury, Oeconomicus, and Symposium by Xenophon. New York: Cornell UP, 1996.

Barrow, Robin \& Geoffery Milburn. A Critical Dictionary of Educational Concepts: An Appraisal of Selected Ideas and Issues in Educational Theory and Practice. $2^{\text {nd }}$ Ed. Ed. Robin Barrow and Geoffery Milburn. New York: Harvester Wheatsheaf, 1990.

Beck, Sanderson. "Confucius and Socrates Compared." Confucius and Socrates : Teaching Wisdom. New York: World Peace Communications, 2006.

Biggs, J. "Western Misperceptions of the Confucian-Heritage Learning Culture.” In D. Watkins and J. Biggs (eds.) The Chinese Learner: Cultural, Psychological, and Contextual Influences. Hong Kong: The University of Hong Kong, 1996.

Bonnette, Amy L. Memorabilia of Xenophon. New York: Cornell UP, 1994.

Bostock, D. Plato’s Theaetetus. Oxford: Oxford UP, 1988. 
Brislin, R. W., Bochner, S., \& Lonner, W. J. Cross-Cultural Perspectives on Learning. Beverley Hills, CA: Sage Publications, 1975.

Bruner, J. The Culture of Education. Cambridge, MA: Harvard University Press, 1996.

Burbules, Nicholas C. "Philosophy of Education." Routledge International Companion to Education. Ed. Bob Moon, Miriam Ben-Peretz and Sally Brown. London: Routledge, 2000.

Carr, David. "Exploring Theory and Practice in Moral Education." Routledge International Companion to Education. Ed. Bob Moon, Miriam Ben-Peretz and Sally Brown. London: Routledge, 2000.

Chambliss, J. J. "History of Philosophy of Education." Philosophy of Education: An Encyclopaedia. Ed. J. J. Chambliss. New York: Garland Publishing, Inc., 1996.

Channing, Viv \& Karl Aubrey. "Learning." A Dictionary of Education. Ed. Susan Wallace. Oxford: OUP, 2008.

Chen, Jingpan. Confucius as a Teacher. Beijing: Foreign Languages Press, 1990.

Cheng, K. M. The Quality of Primary Education: A Case Study of Zhejiang Province, China. Paris: International Institute for Educational Planning, 1996.

Cheng, X. “Asian Students’ Reticence Revisited.” System 28 (2000): 435-446.

“Confucianism.” Encyclopcedia Britannica. Encyclopædia Britannica Online. 28 Nov.

$<$ http://www.britannica.com/EBchecked/topic/132104/Confucianism>.

Cooper, John M. “Socrates.” The Shorter Routledge Encyclopedia of Philosophy. Ed. Edward Craig. London: Routledge, 2005.

Copleston, Frederick. A History of Philosophy. New York: Doubleday \& Company, 1962. 
Crook, David. "Teaching/Teaching Methods." The Routledge International Encyclopaedia of Education. Ed. Gary McCulloch and David Crook. London: Routledge, 2008.

Cortazzi, M. and Jin, L. "Cultures of learning: Language classrooms in China.” In J.Coleman (ed.) Society and the Language Classroom. (pp. 169-206).

Cambridge: Cambridge University Press, 1996.

Cortazzi, M. and Jin, L. "Cultures of learning: The social construction of educational identities.” In D.C.S. Li (ed.) Discourses in Search of Members: In Honor of Ron Scollon. New York: American Universities Press, 2002.

Cummings, W. “Asian Values, Education and Development." Compare 26.3(1996): $287-304$.

Curren, Randall. Philosophy of Education: An Anthology. Malden \& Oxford: Blackwell Publishing Ltd., 2007.

Deci, E. L. \& Ryan, R. M. Intrinsic Motivation and Self-Determination in Human Behavior. New York: Academic Press, 1985.

Desforges, Charles. "Learning." Routledge International Companion to Education. Ed.Bob Moon, Miriam Ben-Peretz and Sally Brown. London: Routledge, 2000. Feng, Yulan. History of Chinese Philosophy. Trans. Derk Bodde. Princeton: Princeton UP, 1983.

Forrester, Gillian, Motteram, Gary and Liu Bangxiang. "Transforming Chinese teachers' thinking, learning and understanding via e-learning." Journal of Education for Teaching 32.2 (2006):197-212.

Gao, Simon S. and Morrison Handley Schachler. "The Influence of Confucianism, Feng Shui and Buddhism in Chinese Accounting History." Accounting, 
Business \& Financial History, Volume 13. 1 (2004):11-19. Web. 3 June 2008. www.taylorandfrancis.metapress.com/index/0L0UJH89A2LYRMBQ.pdf

Gernet, Jacques. Daily Life in China on the Eve of the Mongol Invasion, 1250-1276.

Translated by H.M. Wright. Stanford: Stanford University Press, 1962.

Gieve, Simon \&.Clark, Rose. "The Chinese approach to learning: Cultural trait or situated response? The case of a self-directed learning programme." System, Vol. 33 Issue 2, Jun (2005): 261-276.

Gill, Mary Louise \&. Pierre Pellegrin. A Companion to Ancient Philosophy. Hong Kong: John Wiley \& Sons, 2009.

Grayling, A.C. Philosophy 1: A Guide through the Subject. Hong Kong: Oxford University Press, 1998.

Greenfield, P. M. "Culture as process: Empirical methods for cultural psychology." In J. W. Berry, Y. H. Poortinga, \& J. Pandey (Eds.), Handbook of cross-cultural psychology: Volume 1: Theory and Method (2nd ed.). Boston, MA: Allyn and Bacon, 1997.

Greenholtz, Joe. "Socratic Teachers and Confucian Learners: Examining the Benefits and Pitfalls of a Year Abroad.” Language and Intercultural Communication 3.2 (2003):122-130. Web. 15 Nov. 2009.

Gurung, Regan A.R. "Comparing Cultural and Individual Learning Tendencies." American Psychologist 58.2 (2003), p145-146.

Gutek, Gerald L. New Perspectives on Philosophy and Education. New Jersey: Pearson Education, Inc. 2009.

Guthrie, W. K. C. Socrates. Cambridge: CUP, 1971. 
Hall, David and Roger Ames, Anticipating China: Thinking Through the Narratives of Chinese and Western Culture. Albany: State University of New York Press, 1995.

Hayhoe, Ruth. Portraits of Influential Chinese Educators. The University of Hong Kong: Hong Kong UP, 2006.

He, H. W. Chinese students' approach to learning English: Psycholinguistic and sociolinguistic perspectives. Unpublished master's thesis, Biola University, La Mirada, CA, 1996.

He, Zhaowu \& Peng Gang. A Critical History of Classical Chinese Philosophy. Beijing: New World Press, 2009.

Holmes, Prue. "Problematising Intercultural Communication Competence in the Pluricultural Classroom: Chinese Students in a New Zealand University." Language \& Intercultural Communication, Vol. 6 Issue 1(2006): 18-34.

Howatson, M. C. and Frisbee C. C. Sheffield. Plato's Symposium. Trans. M. C. Howatson. Cambridge: CUP, 2008.

Huang, C. The Analects of Confucius (Lun Yu): A literal Translation with an Introduction and Notes. Oxford: OUP, 1997.

Huang, J. "Challenges of Academic Listening in English: Reports by Chinese Students.” College Student Journal, 59.3(2005): 553-569.

Huang, Jinyan \&. Brown, Kathleen. "Cultural Factors Affecting Chinese ESL Students’ Academic Learning.” Education, Vol. 129 Issue 4, summer (2009): 643-653.

Hynson, Colin. Ancient Greece. Milwaukee: World Almanac Library, 2006. 
Iyengar, S. S., \& Lepper, M. R. "Rethinking the value of choice: A cultural perspective on intrinsic motivation." Journal of Personality and Social Psychology, 76 (1999): 349-366.

Jaspers, Karl. Socrates, Buddha, Confucius, Jesus-the Paradigmatic Individuals. From The Great Philosophers, Vol. I. Ed. Hannah Arndt. Trans. Ralph Manheim. New York: Harcourt, Brace \&World, Inc., 1957.

Jiang, Hongqing. "On the Academic Achievement of Annotations on the Analects by Bao Xian. ” Journal of Yangzhou University (Humanities and Social Sciences Edition) 14.2 (2010):11-19. Web. 12 July 2010.

Jin, Lixian \&.Cortazzi, Martin. "Changing Practices in Chinese Cultures of Learning.” Language, Culture \& Curriculum, Vol. 19 Issue 1, (2006): 5-20. Joint Association of Classical Teachers' Greek Course. The World of Athens: An Introduction to Classical Athenian Culture. Cambridge: Cambridge UP, 1984.

Kateb, George. "Democratic Individualism and Its Critics." Annual Review of Political Science 6.1 (2003): 275-305. Web. 26 Nov. 2009.

King, Edmund J. Education in World Perspective. London: Methuen, 1962.

Lau, D. C. \& Roger T. Ames. “Confucius.” The Shorter Routledge Encyclopedia of Philosophy. Ed. Edward Craig. London: Routledge, 2005.

Lee, W.O. "The Cultural Context for Chinese Learners: Conceptions of Learning in the Confucian Tradition.” In D.Watkins and J. Biggs (eds) The Chinese Learner: Cultural, Psychological and Contextual Influences. Hong Kong: Comparative Education Research Centre, 1996: 25-41.

Lepper, M. R. \& Malone, T. W. “Intrinsic Motivation and Instructional Effectiveness in Computer-Based Education.” In R. E. Snow \& M. J. Farr (Eds.), Aptitude, 
Learning, And Instruction: Vol. 3. Cognitive and Affective Process Analysis.

Hillsdale, NJ: Erlbaum, 1987.

Li, Fuchen. The Confucian Way. Trans. Shih Shun Liu. London: Routledge, 1986.

Li, Jin. "Learning models in different cultures." New Directions for Child \& Adolescent Development, Vol. 2002 Issue 96, Summer (2002): 45-64.

Li, Jin. "The Core of Confucian Learning." American Psychologist, 58.2 (2003): $146-147$.

Li, Jin. "Learning as a Task or a Virtue: U.S. and Chinese Preschoolers Explain Learning.” Developmental Psychology, vol. 40 Issue 4 (2004): 595-605.

Li, Jin. “'I learn and I grow big': Chinese preschoolers' purposes for learning." International Journal of Behavioral Development, Vol. 28 Issue 2, Mar (2004): $116-128$

Li, Jin. \& Cortazzi M. "Dimensions of dialogue, large classes in China.” International Journal of Educational Research, 29 (1998): 739-761.

Liu, JeeLoo. An Introduction to Chinese Philosophy: From Ancient Philosophy to Chinese Buddhism. Oxford: Blackwell Publishing, 2006.

Lillard, A. "Ethnopsychologies: Cultural variations in theories of mind." Psychological Bulletin 12:3(1998): 3-32.

Luo, Jing. Over A Cup Of Tea: An Introduction to Chinese Life And Culture. Washington, D.C: University Press of America, 2004.

Markus, H. J., \& Kitayama, S. "Culture and the Self: Implications for Cognition, Emotion and Motivation.” Psychological Review, 98(1991): 224-253.

Martin, Bernard and Shui Chien-Tung. "Confucius: The Man who moulded China." Makers of China: Confucius to Mao. Oxford: Basil Blackwell, 1972. 
Miller, Darcy. "Learning Strategies." Encyclopaedia of Educational Psychology. Ed. Neil J. Salkind and Kristin Rasmussen. Vol. 2, London: Sage Publications, 2008.

Moneta, Giovanni B. “The Flow Model of Intrinsic Motivation in Chinese: Cultural and Personal Moderators." Journal of Happiness Studies, Vol. 5 Issue 2, June (2004): 181-217.

Ng, A.K. Why Asians are Less Creative than Westerners. Singapore: Prentice Hall, 2001.

Noddings, Nel. Philosophy of Education. $2^{\text {nd }}$ ed. Colorado: Westview Press, 2007.

“Online Etymology Dictionary.” http://www.etymonline.com. Retrieved 2009-01-06.

Plato. “Meno.” Trans. Benjamin Jowett. 2011. Web. 9 June 2011. http://classics.mit.edu/Plato/meno.html

Pratt, D. D., Kelly, M.and Wong, W. S. S. "Chinese conceptions of 'effective teaching' in Hong Kong: towards culturally sensitive evaluation of teaching." International Journal of Lifelong Education, Vol. 18 Issue 4, July (1999): 241-258.

Pusch, M. D. (Ed.) Multicultural Education. NY: Intercultural Press, Inc., 1979.

Qian, J. Chinese Graduate Students’ Experiences in Writing Literature Review. Unpublished master's thesis. Queen's University, Kingston, Ontario, 2002.

Quinton, Rt. "Philosophy." The Oxford Companion to Philosophy. $2^{\text {nd }}$ Ed. Ed. Ted Honderich. Oxford: OUP, 2005.

Radclyffe-Thomas, Natascha. "Intercultural chameleons or the Chinese way? Chinese students in Western art and design education." Art, Design \& Communication in Higher Education, Vol. 6 Issue 1 (2007): 41-55. 
Reagan, T. Non-Western Educational Traditions - Alternative Approaches to

Educational Thought and Practice (2nd ed.). Mahwah, NJ: Lawrence Erlbaum Associates, 2000.

Richmond, W. Kenneth. Socrates and the Western World: An Essay in the Philosophy of Education. London: Alvin Redman Ltd., 1954.

Rosch, E. "Principles of categorization.” In E. Rosch \& B. B. Lloyd (Eds.), Cognition and Categorization. Hillsdale, NJ: Erlbaum, 1978.

Salili, F., Chiu, C.Y., \& Lai, S. "The influence of culture and context on students' achievement orientations.” In F. Salili, C.Y. Chiu, \& Y.Y. Hong (Eds.), Student Motivation: The Culture and Context of Learning. New York: Plenum Press, 2001.

Santas, Gerasimos Xenophon. Socrates: Philosophy in Plato's Early Dialogues. London: Routledge \& Kegan Paul, 1979.

Sansone, David. Ancient Greek Civilization. $2^{\text {nd }}$ ed. Oxford: Blackwell Publishing Ltd, 2009.

Schieder, W. "Real slave prices and the relative cost of slave labor in the Greco-Roman world", Ancient Society, vol. 35 (2005): 30-45.

Schwartz, Benjamin I. The World of Thought in Ancient China. Cambridge: Belknap Press of Harvard University Press, 1985.

Scott, Gary Alan. Plato's Socrates as Educator. NY: State University of New York Press, 2000.

Sealey, Raphael. A History of the Greek City States, ca. 700-338 B.C. Cambridge: University of California Press, 1976.

Senchuk, Dennis M. "Philosophy of Education." The Cambridge Dictionary of Philosophy. $2^{\text {nd }}$ ed. Ed. Robert Audi. Cambridge: CUP, 1995. 
Shen, Jianping. “Confucius.” Fifty Major Thinkers on Education: From Confucius to Dewey. Ed. Joy Palmer. London: Routledge, 2001.

Sichel, Betty A. "Socrates." Philosophy of Education: An Encyclopedia. Ed. J. J. Chambliss. New York: Garland Publishing, Inc., 1996.

“Socrates." The Cambridge Dictionary of Philosophy. $2^{\text {nd }}$ Ed. Ed. Robert Audi. Cambridge: CUP, 1995.

Solas, Cigdem and Sinan Ayhan: "The historical evolution of accounting in China: the effects of culture." Spanish Journal of Accounting History No. 7 Diciembre (2007): 150-165.

Sowerby, Robin. The Greeks: An Introduction to Their Culture. $2^{\text {nd }}$ ed. London and New York: Routledge, 2009.

Starr, Chester G. A History of the Ancient World. $3^{\text {rd }}$ ed. Oxford: Oxford UP, 1983.

Strauss, Leo. The City and Man. Chicago: University of Chicago Press, 1964.

Tarnas, Richard. The Passion of the Western Mind. New York: Ballantine Books, 1991.

Teichman, Jenny and Katherine C. Evans. Philosophy: A Beginner's Guide. 1st ed. Oxford: Basil Blackwell Ltd, 1991.

TenHouten, Warren D. and Wen Wang. "The Eight Trigrams of the Chinese I Ching and the Eight Primary Emotions." Asian Journal of Social Psychology 4. 3(2001) 185-199. Web. 15 Nov. 2009.

The Analects of Confucius. Trans. Arthur Waley. London: Unwin Hyman, 1988.

The Analects of Confucius. Trans. A. Charles Muller.1990. Revised. Web. 12 Jan. 2010. http://www.acmuller.net/con-dao/analects.html.

The Analects of Confucius. Trans. William Edward Soothill. Yokohama: F.H. Revell, 1910. 
The Chinese Classics. $2^{\text {nd }}$ ed. Trans. James Legge. Oxford: Clarendon Press, 1893.

The Four Books: Confucian Analects, the Great Learning, the Doctrine of the Mean, and the Works of Mencius. Trans. James Legge. Shanghai: The Commercial Press, 1900.

The Illustrated Catalogue of Chinese Government Exhibits for the International Exhibition of Chinese Art in London. Cambridge: CPU, 1985.

Thomas, Carol G. Paths from Ancient Greece. Leiden, Netherlands: E. J. Brill, 1988.

Thornton, Bruce. Greek Ways: How the Greeks Created Western Civilization. Encounter Books, 2002

Triandis,H.C., McCusker and C.H. Hui. "Multimethod probes of individualism and collectivism.” Journal of Personality and Social Psychology 59 (1990): $1006-1020$.

Tweed, R. and Lehman, D. "Learning considered within a cultural context: Confucian and Socratic approaches.” American Psychologist 57.2(2002), 89-99.

Tu, W. M. Humanity and Self-Cultivation: Essays in Confucian Thought. Berkeley, Calif.: Asian Humanities Press, 1979.

Upton, T. A. "Chinese students, American universities, and cultural confrontation." Minne TESOL Journal, 7 (1989): 9-28.

Wan, Guofang. "The Learning Experience of Chinese Students in American Universities: A Cross-Cultural Perspective.” College Student Journal, Vol. 35, Issue 1. Mar(2001): 28-45.

Warburton, Nigel. Philosophy: the Basics. $4^{\text {th }}$ ed. London: Routledge, 2004.

Watkins, D. A. "Learning and teaching: A cross-cultural perspective.” School Leadership \& Management 20.2 (2000): 161-173. 
Watkins, D.A., \& Biggs, J.B. The Chinese Learner: Cultural, Psychological, and Contextual Influences. Hong Kong: Comparative Education Research Centre (CERC), 1996.

Watts, Alan \&. Huan, Al Chung-liang. Tao: The Watercourse Way. New York: Pantheon Books, 1975.

West, Thomas G. Plato’s “Apology of Socrates.” New York: Cornell UP, 1979.

West, Thomas G. and Grace Starry West. Four Texts on Socrates: Plato's Euthyphro, Apology, and Crito, and Aristophanes' Clouds. Trans. Thomas G. West and Grace Starry West. New York: Cornell UP, 1998.

White, John. "Philosophy of Education." The Routledge International Encyclopaedia of Education. Ed. Gary McCulloch and David Crook. London: Routledge, 2008

Wieger, Leo. A History of the Religious Beliefs and Philosophical Opinions in China: From the Beginning to the Present Time. Trans. Edward Chalmers Werner. Peking: Hsien-hsien Press, 1927.

Wing On, L. "The cultural context for Chinese learners: Conceptions of learning in the Confucian tradition.” In D. Watkins and J. Biggs (eds) The Chinese Learner: Cultural, Psychological and Contextual Influences. Hong Kong: CERC, 1996.

Wu, D.Y.H., \& Tseng, W.-S. "Introduction: The characteristics of Chinese culture." In D.Y.H. Wu \& W.-S. Tseng (Eds.), Chinese Culture and Mental Health. New York: Academic Press, 1985.

Xenophon. "Apology of Socrates to the Jury." Trans. Andrew Patch, in Shorter Socratic writings. New York: Cornell UP, 1996: 9-17.

Yao, Xinzhong. An Introduction to Confucianism. Cambridge: CUP, 2000. 
Yu, A.-B. "Ultimate Life Concerns, Self, and Chinese Achievement Motivation." In M. Bond (ed.), The Handbook of Chinese Psychology. New York: Oxford University Press, 1996.

Zhu, Chang; Valcke, Martin; and Schellens, Tammy. "A cross-cultural study of Chinese and Flemish university students: Do they differ in learning conceptions and approaches to learning?" Learning \& Individual Differences, Vol. 18 Issue 1 Jan (2008): 120-127. 


\title{
CURRICULUM VITAE
}

\author{
WANG Heng \\ Continuing Education College, \\ Beijing Foreign Studies University, Beijing, 100089 \\ Mobile: (86) 18618157478 \\ E-mail: chriswh@163.com
}

\section{Education}

09/2000-03/2003

School of English and International Studies, Beijing Foreign Studies University (BFSU), Beijing.

Degree obtained: MA in Linguistics

09/1996-07/2000 Department of Foreign Languages, Beijing Institute of Technology (BIT), Beijing.

Degree obtained: BA in English

\section{Professional Experience}

02/2013-now

Lecturer and teacher of Chinese language, Confucius Institute at the University of Vienna, Austria.

07/2009-07/2010 Visiting scholar at Faculty of Education, University of Cambridge, UK.

04/2003-02/2013 Lecturer, Continuing Education College (CEC), BFSU.

\section{Research Interests}

1. Cultural studies

2. Socratic and Confucian education philosophies

3. Second language acquisition

\section{Major Papers}

- Wang, H. (2010). The Influence of the Socratic Tradition on Cambridge Practice and Its Implication on Chinese Higher Education. Journal of Cambridge 
Studies. Volume 5(1): 1-18.

- Wang, H. (2008). A Tentative Analysis of 'Face' in the Chinese Request. Intercultural Communication Studies. XVII: 1, 207-217.

- Wang, H. (2008). Postmodern Space in the National Olympic Stadium. The Intercultural Forum. Volume 1(3) 2008. Net version available at http://comm.louisville.edu/iic/IF\%20Journal/IF\%201(3)\%202008/if1(3) 2008-wang-heng.html

- Wang, H. (2007). Integrating Cognitive with Affective learning in Online Education. Proceedings of China 2007 Conference on Online Foreign Language Education. Net version available at http://www.beiwaionline.com/zhuanti/07yth/defaultc.htm

\section{Major Honors}

2009 Excellent Teacher Award of the Predeparture Training Department, Ministry of Education

2007 One of the Top Ten Excellent Teachers in the online education programs of BFSU.

2006 One of the most popular teachers in the English Department (the $1^{\text {st }}$ Department) of Training College, BFSU

2005 One of the Top Ten Excellent Teachers in the online education programs of BFSU.

2002 Huawei Scholarship, the highest scholarship in BFSU

2001 Excellent Graduate Scholarship, BFSU

1999 Xu Teli Outstanding Scholarship, the highest scholarship in BIT

1998 SMC Scholarship, BIT 